\title{
Assessment of Habitat, \\ Fish Communities, and Streamflow Requirements for Habitat Protection, Ipswich River, Massachusetts, 1998-99
}

Water-Resources Investigations Report 01-4161
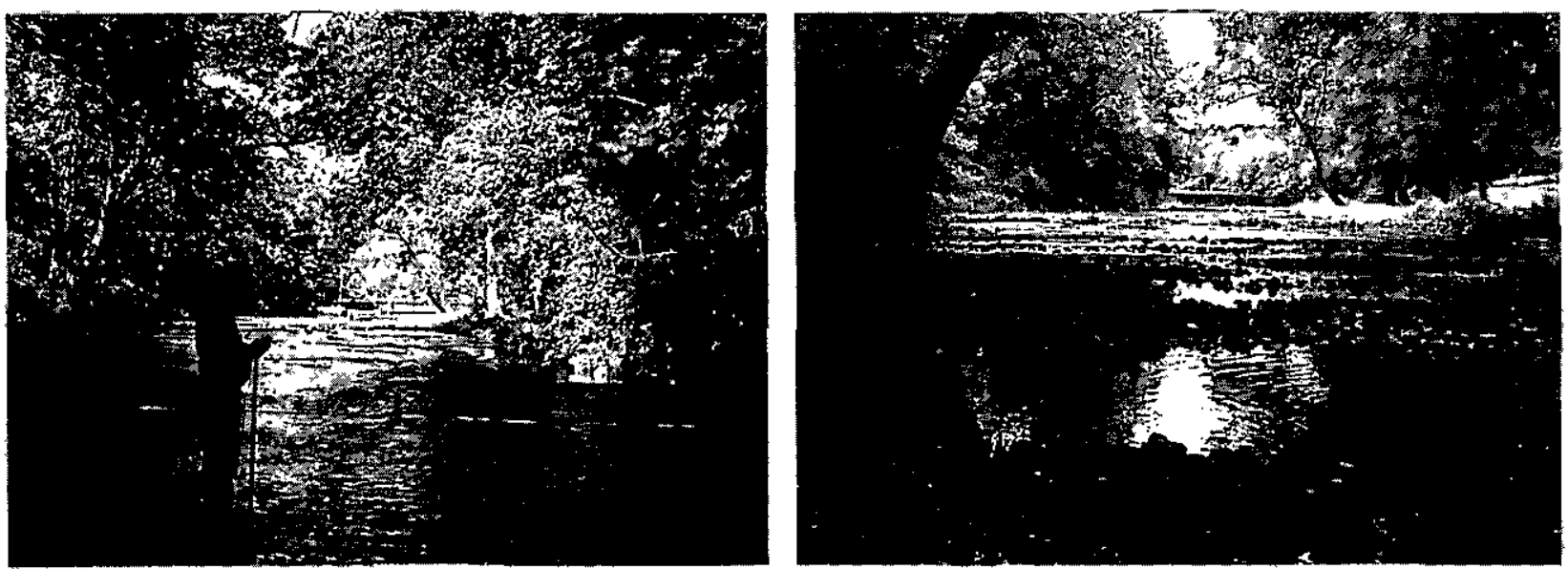

Prepared in cooperation with the

MASSACHUSETTS DEPARTMENT OF ENVIRONMENTAL MANAGEMENT;

MASSACHUSETTS DEPARTMENT OF ENVIRONMENTAL PROTECTION; and the MASSACHUSETTS DEPARTMENT OF FISHERIES, WILDLIFE, AND ENVIRONMENTAL LAW ENFORCEMENT, MASSACHUSETTS DIVISION OF FISHERIES AND WILDLIFE 
Cover Photos: View of the Ipswich River downstream of the Willowdale dam and Ipswich gaging station (01102000).

Photo courtesy of David Armstrong and Timothy Driskell, U.S. Geological Survey, Northborough, Mass. 
U.S. Department of the Interior

U.S. Geological Survey

\section{Assessment of Habitat,} Fish Communities, and Streamflow Requirements for Habitat Protection, Ipswich River, Massachusetts, 1998-99

By DAVID S. ARMSTRONG, TODD A. RICHARDS (Massachusetts Division of Fisheries and Wildlife), and GENE W. PARKER

Water-Resources Investigations Report 01-4161

Prepared in cooperation with the MASSACHUSETTS DEPARTMENT OF ENVIRONMENTAL MANAGEMENT; MASSACHUSETTS DEPARTMENT OF ENVIRONMENTAL PROTECTION; and the MASSACHUSETTS DEPARTMENT OF FISHERIES, WILDLIFE, AND ENVIRONMENTAL LAW ENFORCEMENT, MASSACHUSETTS DIVISION OF FISHERIES AND WILDLIFE 


\section{U.S. DEPARTMENT OF THE INTERIOR \\ GALE A. NORTON, Secretary}

U.S. GEOLOGICAL SURVEY

Charles G. Groat, Director

The use of trade or product names in this report is for identification purposes only and does not constitute endorsement by the U.S. Government.

For additional information write to:

Chief, Massachusetts-Rhode Isiand District

U.S. Geological Survey

Water Resources Division

10 Bearfoot Road

Northborough, MA 01532

or visit our Web site at

http://ma.water.usgs.gov
Copies of this report can be purchased from:

U.S. Geological Survey

Branch of Information Services

Box 25286

Denver, CO 80225-0286 


\section{CONTENTS}

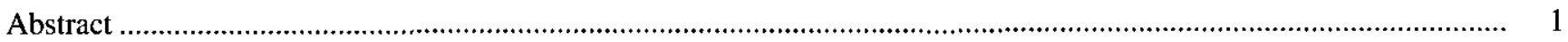

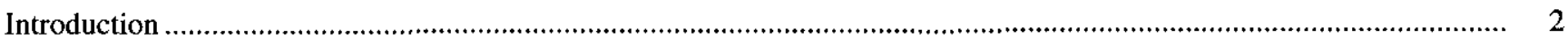

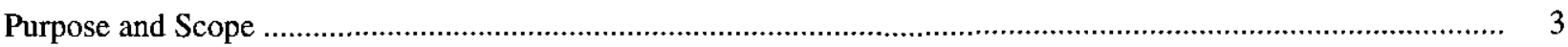

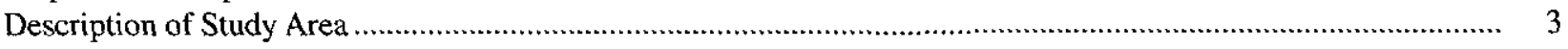

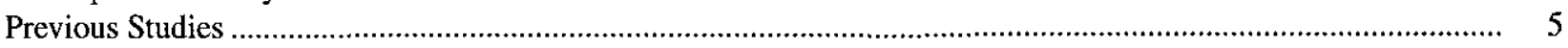

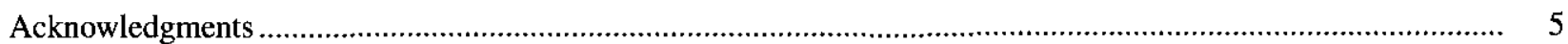

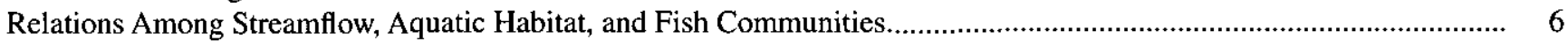

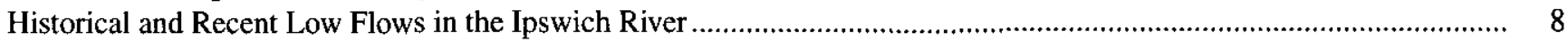

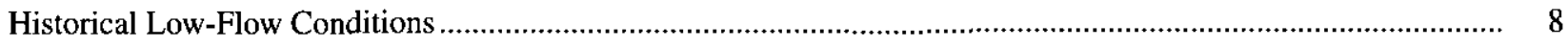

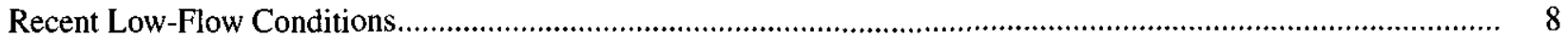

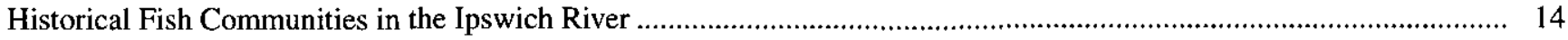

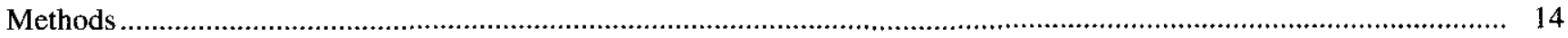

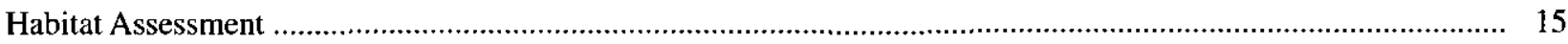

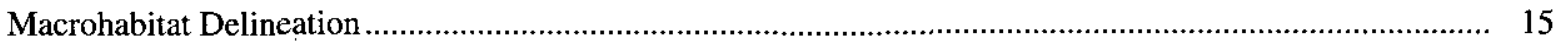

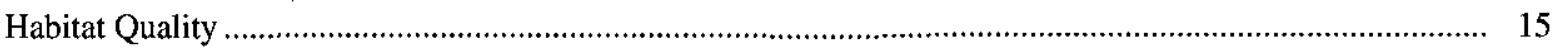

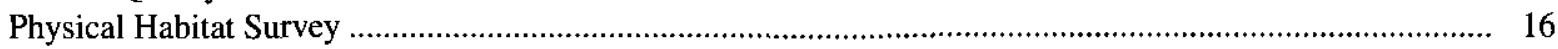

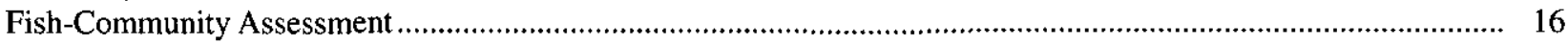

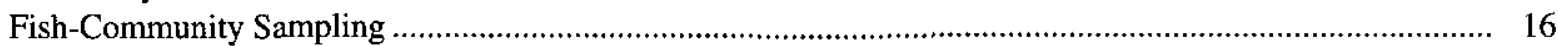

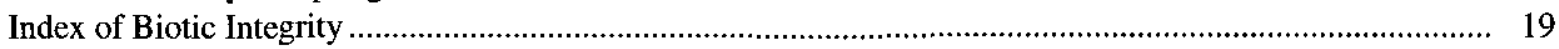

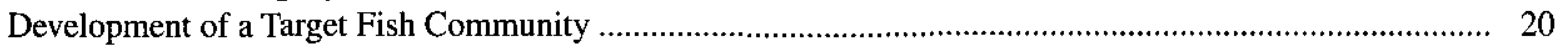

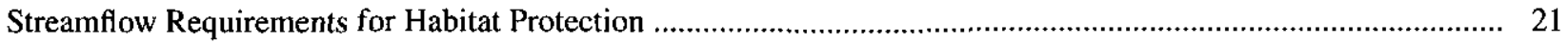

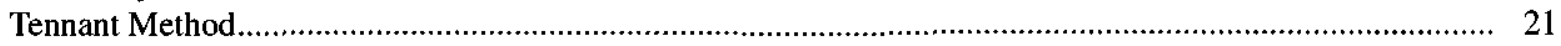

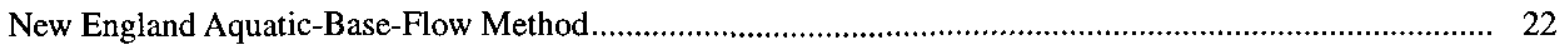

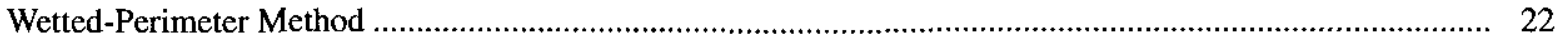

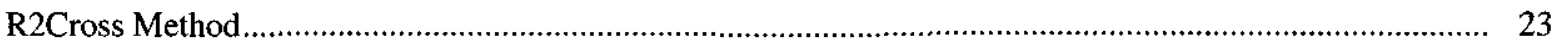

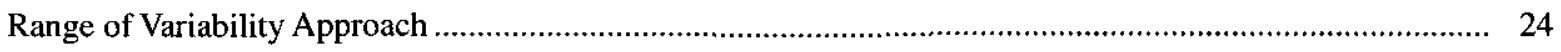

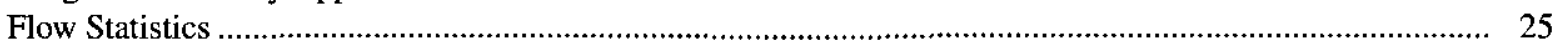

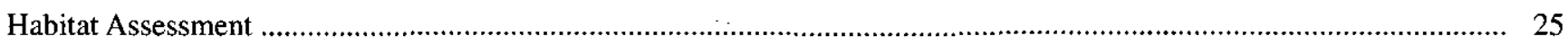

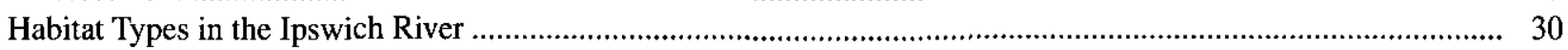

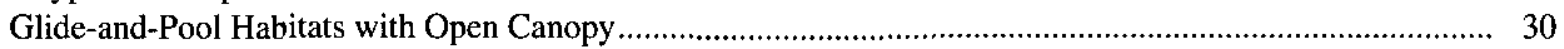

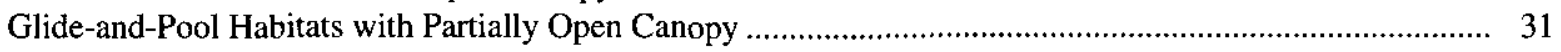

Glide-and-Pool Habitats with Partially Closed and Closed Canopy .................................................... 32

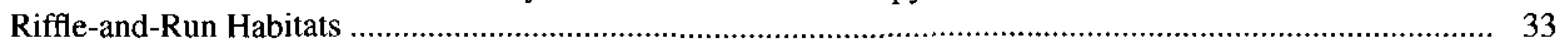

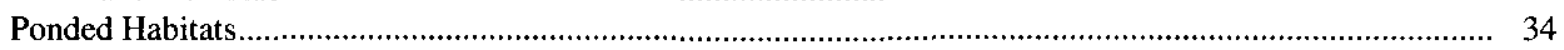

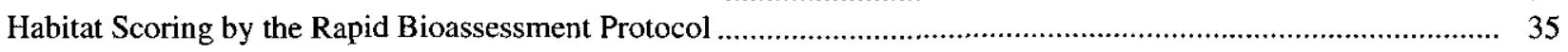

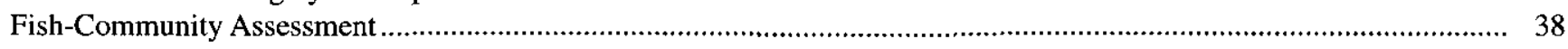

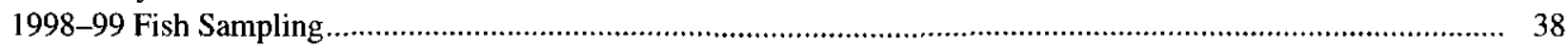

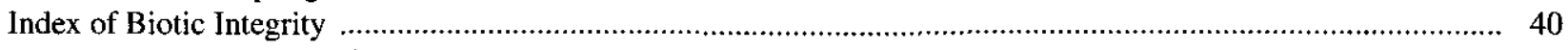

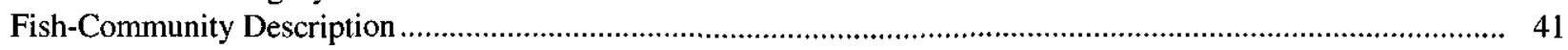

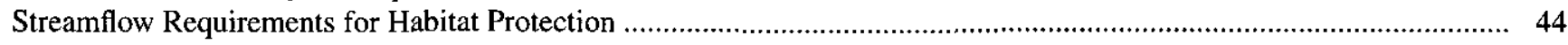

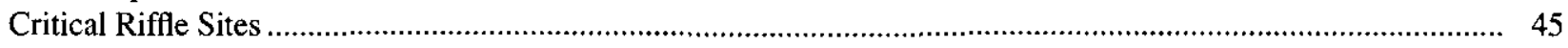

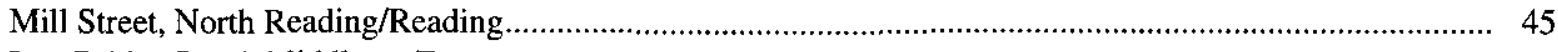

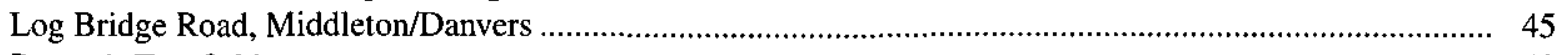

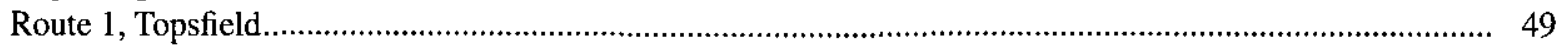

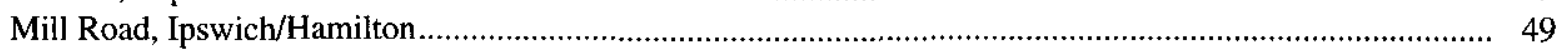

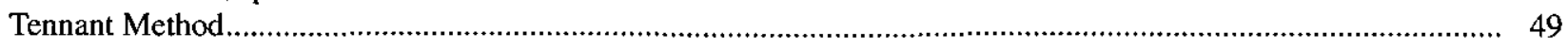

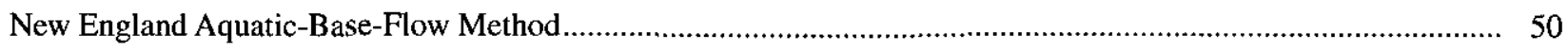

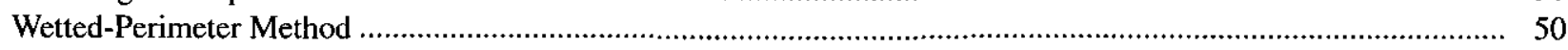




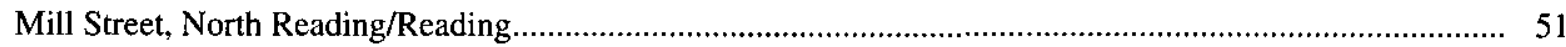

Log Bridge Road, Middleton/Danvers ................................................................................................ 52

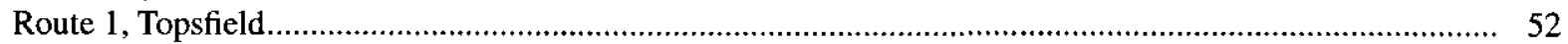

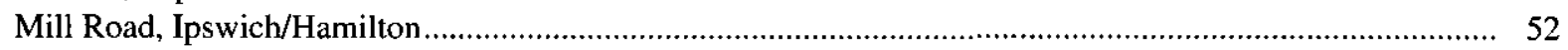

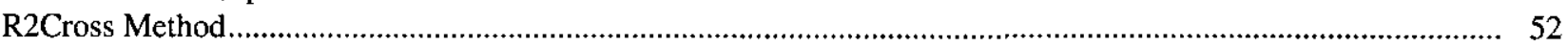

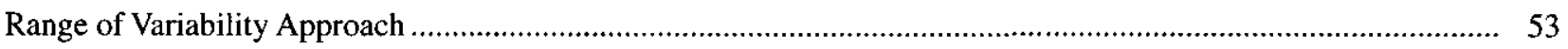

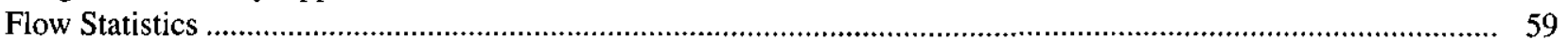

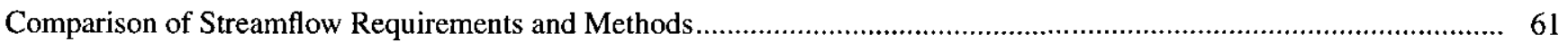

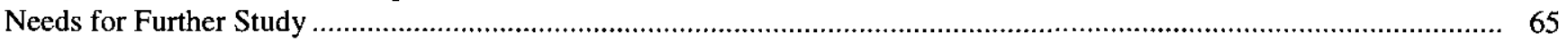

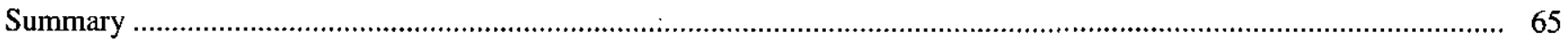

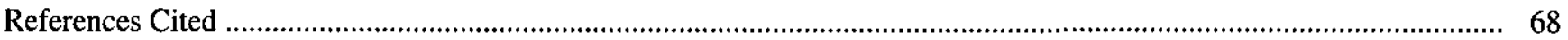

Appendix A: Photographs of Selected Study Sites, Ipswich River Basin, Massachusetts, 1998-99....................... CD-ROM

Appendix B: Physical Habitat Data Collected at Habitat Transects, Ipswich River Basin,

Massachusetts, 1998-99 ………….................................................................................... CD-ROM

Appendix C: Length-Frequency Distributions by Species, Ipswich River Basin, Massachusetts, 1998-99 ............. CD-ROM

Appendix D: Length-Frequency Distributions by Site, Ipswich River Basin, Massachusetts, 1998-99 ................... CD-ROM

\section{FIGURES}

(Photographs are shown in color on CD-ROM)

1. Map showing location of towns, drainage network, impoundments, gaging stations, and fish and habitat assessment sites, Ipswich River Basin, Massachusetts....

2. Box plots showing distribution of monthly mean flow for August for 30 gaging stations in southern New England.

3. Photographs showing $(A)$ fish kills and $(B)$ mussel die-offs in the Ipswich River, 1995 and $1999 \ldots \ldots \ldots \ldots \ldots \ldots \ldots \ldots . .10$

4. Hydrograph showing daily mean discharge and median of daily mean discharge for period of record for

$(A)$ South Middleton and $(B)$ Ipswich gaging stations, water years 1998-99

5, 6. Photographs showing:

5. Stream habitats on the mainstem Ipswich River, during low-flow conditions, 1999. (A) Dry streambed downstream of I-93, North Reading/Reading, downstream view; $(B)$ Dry streambed, North Reading/Reading, upstream view; $(C)$ Isolated pool downstream of I-93 North Reading/ Reading, view of left bank; $(D)$ Isolated pool upstream of Mill Street, North Reading/Reading, upstream view.

6. Massachusetts Division of Fisheries and Wildlife personnel backpack electrofishing on the Ipswich River

7,8. Schematic diagrams showing:

7. (A) Hypothetical stream-channel cross section and $(B)$ Graph of relation between wetted perimeter and discharge.

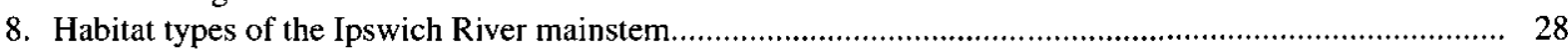

9-16. Photographs showing:

9. Common habitat features along the Ipswich River: $(A)$ woody debris, downstream view; $(B)$ undercut banks and exposed roots, view of right bank ; $(C)$ overhanging shrubs, downstream view, and $(D)$ submerged, emergent, and floating aquatic vegetation, upstream view.

10. Glide-and-pool habitats with an open canopy, Audubon Wildlife Sanctuary, Ipswich River, downstream view.

11. Glide-and-pool habitats with a partially open canopy, upstream of Route 114, Middleton/Danvers, Ipswich River, downstream view.

12. Glide-and-pool habitats with a partially closed or closed canopy, Massachusetts Audubon Society, Ipswich River Wildlife Sanctuary, Ipswich River, Topsfield, upstream view

13. Riffle-and-run habitat: $(A)$ Naturally occurring riffle downstream of Route 1, Topsfield, downstream view; and $(B)$ Altered riffle, Washington Street, North Reading, upstream view, Ipswich River

14. Ponded habitat, Salem-Beverly water supply canal, Topsfield, Ipswich River, southeast view .................. 35

15. (A) South Middleton Dam, Middleton, view of right bank; $(B)$ Willowdale Dam, Ipswich/Hamilton, upstream view; and $(C)$ Sylvania Dam with fish ladder, view of right bank Ipswich River..... 
16-19. Pie charts showing:

16. Fish-species habitat classifications on the (A) Mainstem in 1998, and (B) Tributaries in 1999, Ipswich River.

17. Fish-species habitat classifications for tributaries to the Ipswich River: $(A)$ Howlett Brook, $(B)$ Martins Brook, young-of-year removed, $(C)$ Fish Brook, young-of-year removed.

18. Fish-species habitat classifications for two New England streams: $(A)$ Quinebaug River, Massachusetts, and $(B)$ Lamprey River, New Hampshire.

19. Target fish community, Quinebaug River.

20. Photographs showing stream channels at six critical riffle sites under flowing and dry (or nearly dry) conditions, Ipswich River: $(A)$ Downstream of Mill Street, North Reading/Reading, upstream view; $(B)$ Upstream of Russell Street and Middleton gage (01101500), Middleton, downstream view; $(C)$ Log Bridge Road, Middleton/Danvers, upstream view; $(D)$ Downstream of Route 1, Topsfield, upstream view; $(E)$ Downstream of Ipswich gage (01102000), Ipswich/Hamilton, upstream view; Ipswich/Hamilton

(F) Downstream of Mill Road, Ipswich/Hamilton, upstream view

21-25. Graphs showing:

21. Mean annual flow (QMA) and streamflow requirements determined by the Tennant method for (A) Mill Street, North Reading/Reading, (B) Ipswich River at South Middleton (01101500), (C) Log Bridge Road, Middleton/Danvers, $(D)$ Route 1, Topsfield, (E) Ipswich River near Ipswich (01102000), and $(F)$ Mill Road, Ipswich/Hamilton

22. Streamflow requirements determined by the New England Aquatic-Base-Flow summer-default flow and the median of monthly mean flows for August at $(A)$ Mill Street, North Reading/Reading, (B) Ipswich River at South Middleton (01101500), (C) Log Bridge Road, Middleton/Danvers, $(D)$ Route 1, Topsfield, (E) Ipswich River near Ipswich (01102000), and (F) Mill Road, Ipswich/Hamilton.

23. Streamflow requirements determined by the wetted-perimeter method at four riffle sites: $(A)$ Mill Street, North Reading/Reading, $(B)$ Log Bridge Road, Middleton/Danvers, $(C)$ Route 1, Topsfield, and $(D)$ Mill Road, Ipswich/Hamilton

24. Streamflow requirements determined by the R2Cross method at four riffle sites: $(A)$ Mill Street, North Reading/Reading, $(B)$ Log Bridge Road, Middleton/Danvers, $(C)$ Route 1, Topsfield, and $(D)$ Mill Road, Ipswich/Hamilton ....

25. Flow-duration curves for six sites on the Ipswich River

\section{TABLES}

1. One-day and 7-day annual low flows at the Ipswich River at South Middleton (01101500) gaging station, Middleton/Peabody, Massachusetts

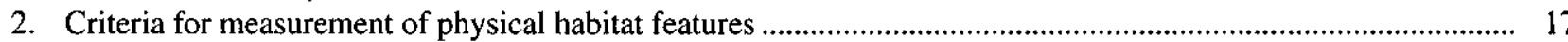

3. Index of Biotic Integrity Metrics .................................................................................................... 20

4. Relations between aquatic habitat condition and mean annual flow described by the Tennant method for small streams.....

5. Seasonal New England Aquatic-Base-Flow default streamflow requirements ................................................

6. R2Cross criteria for hydraulic parameters for protection of aquatic habitat .................................................. 24

7. Range of variability approach: flow statistics for characterization of intra-annual hydrologic variation............... 24

8. Site name, site identifier, date sampled, and location of sample sites, Ipswich River Basin................................. 26

9. Location and length of riffle reaches on the mainstem Ipswich River......................................................... 33

10. U.S. Environmental Protection Agency Rapid Bioassessment Protocol habitat scores for Ipswich River study reaches, $1998-99$

11. Fish sampling date, electroshocking effort, reach length, on the mainstem in 1998 and tributaries in 1999 , Ipswich River.

12. Mean length, number, and percent of total fish by species collected in the mainstem in 1998 and tributaries in 1999, Ipswich River

13. Habitat-use classifications of fish in the Ipswich River Basin

14. The mean annual flow statistic used by the Tennant method and the streamflows representing summer habitat conditions determined by the 10- and 30-percent values of the mean annual flow, normalized for drainage area at six sites in the Ipswich River Basin 


\title{
Assessment of Habitat, Fish Communities, and Streamflow Requirements for Habitat Protection, Ipswich River, Massachusetts, 1998-99
}

\author{
By David S. Armstrong, Todd A. Richards, and Gene W. Parker
}

\begin{abstract}
The relations among stream habitat, fish communities, and hydrologic conditions were investigated in the Ipswich River Basin in northeastern Massachusetts. Data were assessed from 27 sites on the mainstem of the Ipswich River from July to September 1998 and from 10 sites on 5 major tributaries in July and August 1999. Habitat assessments made in 1998 determined that in a year with sustained streamflow for most of the summer, the Ipswich River contains diverse, highquality aquatic habitat. Channel types are predominantly low gradient glides, pools, and impoundments, with a sandy streambed and a forest or shrub riparian zone. Features that provide fish habitat are located mostly along stream margins; these features include overhanging brush, undercut banks, exposed roots, and woody debris. These habitat features decrease in availability to aquatic communities with declining streamflows and generally become unavailable after streamflows drop to the point where the edge of water recedes from the stream banks.
\end{abstract}

The mainstem and tributaries were sampled to determine fish species composition, relative abundance, and length frequency. Fish sampling indicates that the fish community in the Ipswich River is currently a warm-water fish community dominated by pond-type fish. However, historical temperature data, and survival of stocked trout in the mainstem Ipswich into late summer of 1998, indicate that the Ipswich River potentially could support cold-water fish species if adequate flows are maintained. Dominant fish species sampled in the mainstem Ipswich River were redfin pickerel (Esox americanus), American eel (Anguilla rostrata), and pumpkinseed (Lepomis gibbosus), which together represented 41,22 , and 10 percent, respectively, of 4,745 fish sampled. The fish communities of the mainstem and tributaries contained few fluvial-dependent or fluvial-specialist species (requiring flow), and were dominated by macrohabitat generalists (tolerant of low-flow, warmwater, and ponded conditions). In comparison to a nearby river (Lamprey River, N.H.), and a reference fish community developed for inland New England streams, the Ipswich fish community would be expected to have appreciably higher percentages of fluvial-dependent and fluvial-specialist species were streamflows restored.

Four riffle sites on the mainstem of the Ipswich River were identified as critical habitat areas because they are among the first sites to exhibit fish-passage problems or to dry during low flows. A watershed-scale precipitation-runoff model previously developed for the Ipswich River was used to simulate streamflows at these four sites for the period 1961-95 under no withdrawals (for water supply) and 1991 land use to evaluate habitat suitability under conditions that approximate the natural flow conditions. These simulated flows were used to calculate streamflow requirements by the Tennant and New England 
Aquatic-Base-Flow methods. Stream channels were surveyed at the critical riffle sites, and Water Surface Profile models were used to simulate streamflows and hydraulic characteristics needed for determining streamflow requirements by use of the Wetted-Perimeter and R2Cross methods. Normalized by drainage area to units of cubic feet per second per square mile, these methods yielded the following streamflow requirements: 0.50 cubic feet per second per square mile for the Tennant 30percent QMA method, 0.42 cubic feet per second per square mile for the wetted-perimeter value necessary to maintain wetted perimeter at three altered riffle sites, 0.42 cubic feet per second per square mile for the R2Cross value required to maintain R2Cross hydraulic criteria at a natural riffle site, and 0.34 cubic feet per second per square mile for the aquatic-base-flow median of monthly mean flows for August for the simulated 1961-95 period under no withdrawals and 1991 land use. The mean streamflow requirement determined from these four methods is 0.42 cubic feet per second per square mile. This flow would represent an average flow-exceedence value for the six study sites of about 77 percent under simulated flows with no withdrawals. For these flows, the 70-, 80-, and 90-percent exceedence flows averaged $0.59,0.37$, and 0.21 cubic feet per second per square mile, respectively, and the 7-day, 10-year low flow statistic at the two gaged sites averaged 0.08 cubic feet per second per square mile. Simulated flows under no withdrawals were used to determine monthly mean flows and other flow statistics used in the Range of Variability Approach to define a flow regime that mimics the river's natural flow regime.

\section{INTRODUCTION}

The Ipswich River Basin is a heavily used surface- and ground-water resource in northeastern Massachusetts. As a result of withdrawals for public water supply, streamflows in the upper third of the basin frequently become very low or cease during the summer. Although the use of a watershed-simulation model has provided information about effects of these withdrawals on streamflow (Zarriello and Ries, 2000), effects on habitat and aquatic biota have not been determined. Federal, State and local agencies are concerned that reduced streamflows in the basin are causing a loss of habitat that supports the biological integrity of the river.

Ground-water withdrawals were shown to decrease summer low flows substantially when compared to low flows calculated for simulations with no ground-water withdrawals (Zarriello and Ries, 2000). These withdrawals deplete streamflow either by intercepting ground water that would have discharged to the stream or by inducing infiltration from the stream to the wells. Streamflows also are reduced because only about 10 to 20 percent of all water withdrawn from the basin is returned to the basin as wastewater--the remainder is discharged from wastewater treatment plants to the Atlantic Ocean (Peter Phippen, Massachusetts Department of Environmental Management, written commun., 1997). During winter and spring (December through May), streamflow is affected by both ground-water pumpage and by surface-water diversions. In addition, changes in land use and increased impervious area through time in the headwaters of the Ipswich River Basin have been demonstrated to reduce infiltration and decrease base flow (Zarriello and Ries, 2000).

Modification of streamflow is one of the most widespread human disturbances of stream environments (Ward and Stanford, 1983; Bain and others, 1988), and the effects of flow modification can devastate the aquatic communities of headwater streams and streams with small drainage basins (Simon, 1999). It can take multiple years for a stream's ecosystem to recover from a drying episode. Consequently, a stream that dries out frequently, such as the Ipswich River, can remain in a continual state of recovery. The first requirement for the optimal production of stream fish and other aquatic life is an adequate supply of water for the entire year (Wickliff, 1945).

In order to meet the requirements of the Massachusetts Water Management Act, the Massachusetts Department of Environmental Protection (MADEP) and Department of Environmental Management (MADEM) need to determine streamflows that will maintain continuous flow in the lpswich 
River, that will provide habitat adequate to sustain aquatic life during low-flow periods, and that will provide the seasonally variable flows necessary to sustain the ecological integrity of the Ipswich River. In order to meet these requirements, the U.S. Geological Survey (USGS) and Massachusetts Division of Fisheries and Wildlife (MDFW), in cooperation with the MADEM and MADEP, began a study in July 1998 of the habitat, fish communities, and streamflow requirements for habitat protection of the Ipswich River and its tributaries.

\section{Purpose and Scope}

The purpose of this report is to describe the stream habitat and fish communities of the Ipswich River, determine relations between flow quantity and habitat, and determine adequate streamflow requirements to maintain quality aquatic habitat in the Ipswich River. The report describes assessments of stream habitats and fish communities conducted in 1998 for the mainstem of the Ipswich River, from its headwaters near Woburn Street in Wilmington to the Sylvania Dam in Ipswich; and assessments conducted in 1999 for selected reaches of Martins Brook, Norris Brook, Boston Brook, Fish Brook, and Howlett Brook. The report also compares streamflow requirements determined by means of the Tennant, New England AquaticBase-Flow (ABF), Wetted-Perimeter, R2Cross methods, and the Range of Variability Approach. Streamflow requirements were determined at the gage sites at South Middleton and Ipswich, and at four riffle sites on the mainstem Ipswich River, located at Mill Street in North Reading/Reading, Log Bridge Road, in Middleton/Danvers, Route 1 in Topsfield, and Mill Road in Ipswich/Hamilton.

\section{Description of Study Area}

The Ipswich River Basin is approximately $25 \mathrm{mi}$ long and about $6 \mathrm{mi}$ wide, and encompasses a $155-\mathrm{mi}^{2}$ area entirely in northeastern Massachusetts about $20 \mathrm{mi}$ northeast of Boston (fig. 1). The Ipswich River begins near the confluence of Maple Meadow Brook, Mill Brook, and Lubbers Brook in Wilmington, and discharges to the Atlantic Ocean at Plum Island Sound.
Major tributaries to the Ipswich include Martins Brook, Norris Brook, Boston Brook, Fish Brook, Gravelly Brook, Howlett Brook, and the Miles River. The tidal portion of the river downstream from the Sylvania Dam in Ipswich was not included in the study area.

The Ipswich River Basin includes all or parts of 22 municipalities (fig. 1). The towns of North Reading, Middleton, and Topsfield are completely within the basin, as are major portions of Wilmington, Reading, North Andover, Boxford, Wenham, Hamilton, and Ipswich. The basin also includes parts of the towns of Burlington, Andover, Lynnfield, Peabody, Danvers, and Beverly, and minor portions of the towns of Woburn, Billerica, Tewksbury, Essex, Georgetown, and Rowley. Many of these municipalities obtain some or all of their water supply from within the Ipswich River Basin. The towns of Salem and Lynn get some of their water supply from the Ipswich River, yet are entirely outside the basin.

The Ipswich River Basin is in the coastal lowland physiographic province of New England (Denny, 1982) and is characterized by low relief, low stream gradients, and slow stream currents. Topography varies from flat terrain to low rounded hills, most of which are less than $300 \mathrm{ft}$ in elevation. The predominant land uses in the drainage basin are residential, forest, and wetland. The river falls about $110 \mathrm{ft}$ from its source to sea level, which is a distance of about $36 \mathrm{mi}$. The average river slope is $3.1 \mathrm{ft} / \mathrm{mi}$, but slopes range from about $6.0 \mathrm{ft} / \mathrm{mi}$ in the headwaters to $1.5 \mathrm{ft} / \mathrm{mi}$ in the middle reaches to $2.8 \mathrm{ft} / \mathrm{mi}$ in the lower third of the river. The gradient of the main channel is further decreased by three dams-the South Middleton Dam in Middleton, the Willowdale Dam in Ipswich/Hamilton, and the Sylvania Dam in Ipswich (fig. 1). Together, these dams account for about $30 \mathrm{ft}$ of vertical drop. Most of the tributaries to the Ipswich also have one or more impoundments that were built for water supply, or to store water to power former gristmills and saw mills. The impoundments behind these dams modify the river by creating long reaches of moderately deep, slowmoving water with characteristics that are more pondlike than riverine. These dams restrict the downstream movement and restrict or preclude the upstream movement of fish between reaches of the Ipswich River, and between the mainstem Ipswich and its tributaries. 
$70^{\circ} 50^{\prime}$

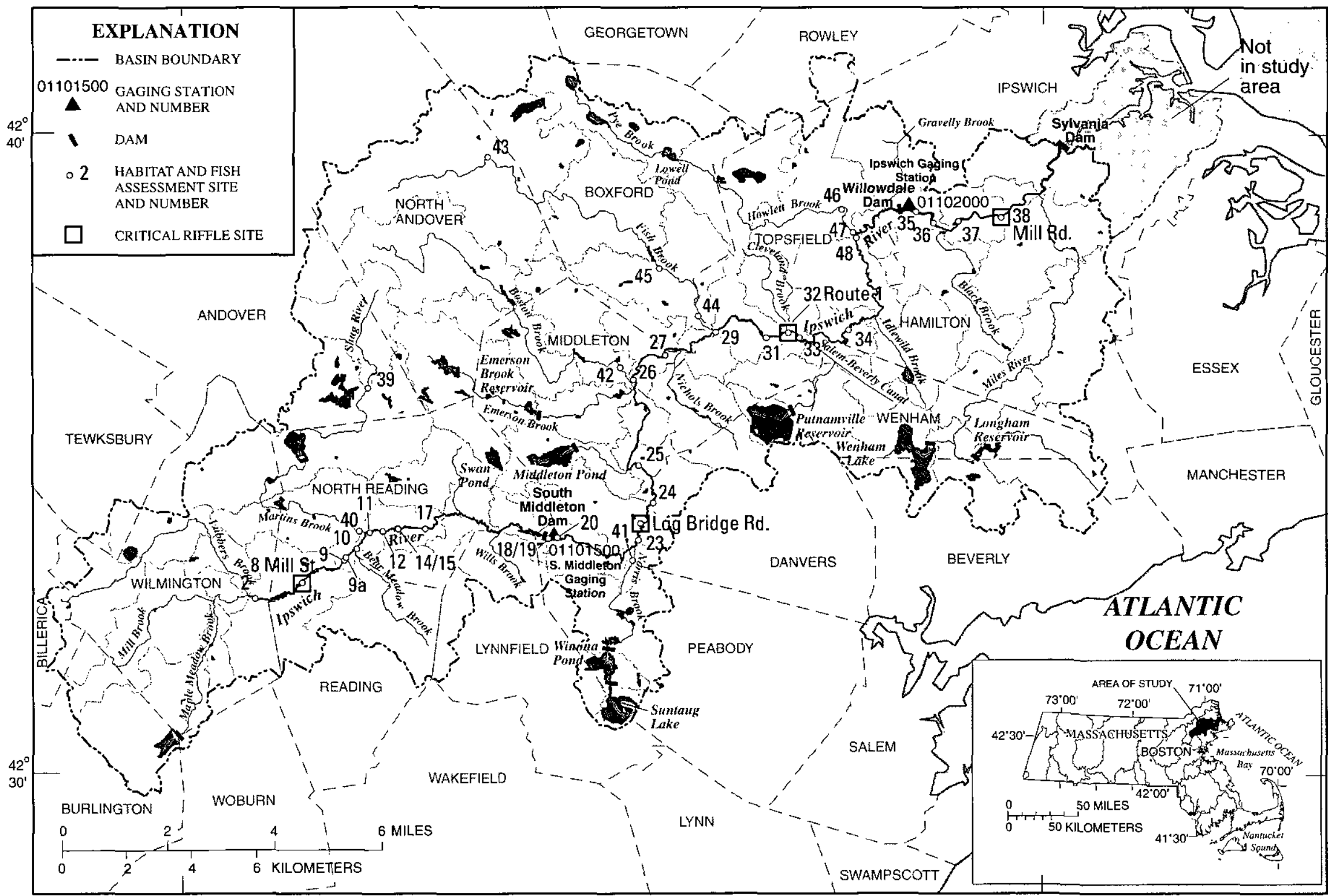

Figure 1. Location of towns, drainage network, impoundments, gaging stations, and fish and habitat assessment sites, Ipswich River Basin, Massachusetts. 
Coarse sand and gravel deposits form the major aquifers in the basin, many of which are developed for municipal supply. Sand and gravel deposits cover about 43 percent of the basin, glacial till covers about 54 percent of the basin, and the remaining 3 percent are recent alluvial deposits (see Zarriello and Ries, 2000). Till typically underlies upland areas, and sand and gravel deposits generally underlie wetlands and other lowland areas. Sand and gravel deposits are not uniformly distributed across the basin. They range from about 65 to 70 percent of the total area in the upper half of the basin to about 40 to 45 percent of the total area in the lower half of the basin. Tributary streams that drain areas of sand and gravel deposits, such as Martins Brook and Howlett Brook, tend to have higher base flow than streams draining areas of till, such as Emerson Brook and Boston Brook.

The Ipswich River has a wide riparian corridor in most places; housing or urban development directly borders the river in only a few locations. Much of the riparian corridor is forested wetland, interspersed with mosaics of meadow and shrub wetlands and patches of upland forest. Water quality in the Ipswich River generally is good. The river has a Class $\mathrm{B}$ rating for water use. A Class $\mathrm{B}$ rating means a river is designated as a habitat for fish, other aquatic life, and wildlife, and for primary and secondary contact recreation; and is designated suitable as a source of public water supply with appropriate treatment, for irrigation and other agricultural uses, and for compatible industrial cooling and process uses, and shall have consistently good aesthetic value (Massachusetts Department of Environmental Protection, 1999). The river transports large amounts of organic material from its extensive wetlands in the form of humic compounds that cause the water to appear tea-colored. Oxidation of this organic matter can depress dissolved oxygen levels in the river. The Ipswich River currently is classified by the MADEP as a warm-water fishery (Massachusetts Department of Environmental Protection, 1999), but has been classified in the past as a seasonal cold-water fishery (Massachusetts Department of Environmental Protection, 1990). The Ipswich River and its tributaries have a fish community represented by a variety of taxa and trophic groups.

The U.S. Geological Survey (USGS) has operated two gaging stations on the mainstem of the Ipswich River since the 1930s (fig. 1). The upstream gaging station at South Middleton (station number 01101500 ) has a drainage area of $44.5 \mathrm{mi}^{2}$, and a mean annual discharge of $63.9 \mathrm{ft}^{3} / \mathrm{s}$; the downstream gaging station near Ipswich (station number 01102000 ) has a drainage area of $125 \mathrm{mi}^{2}$ and a mean annual discharge of $189 \mathrm{ft}^{3} / \mathrm{s}$ (Socolow and others, 1999). Streamflows typically are lowest in July, August, and September. From 1961 to 1995 , median monthly mean flows for July, August, and September were about 10,8, and $15 \mathrm{ft}^{3} / \mathrm{s}$, respectively, at the South Middleton gage; and about 23,20 , and $19 \mathrm{ft}^{3} / \mathrm{s}$, respectively, at the Ipswich gage. Discharge at these sites, however, is affected by water withdrawals upstream of the gaging stations.

\section{Previous Studies}

The USGS began a study in 1995 to determine the spatial distribution and correlation among parameters related to aquatic habitats and flow conditions of Massachusetts streams. The study, done in cooperation with the MADEM, Office of Water Resources and the MADEP, evaluated the applicability of median daily mean flow for August (Ries, 1997) and wettedperimeter measures at gaging stations (Mackey and others, 1998) to determine streamflow requirements for Massachusetts streams. To simulate the hydrology and complex water-use patterns in the Ipswich River Basin, the USGS developed a basin-scale precipitation-runoff model with the Hydrologic Simulation ProgramFortran (HSPF) (Zarriello and Ries, 2000). The model is being used by MADEP and MADEM to calculate the effects of withdrawals on streamflow. Four critical riffle sites identified by this habitat study were included as HSPF model nodes in the hydrologic modeling study. Streamflow requirements determined from streamflows simulated with the HSPF model for those sites are included in this report.

\section{Acknowledgments}

The authors are grateful to the many public agencies, private organizations, and individuals who provided guidance, information, and field assistance during the study, including members of the Massachusetts Streamflow and Habitat Workgroup, Ipswich River Watershed Association, Headwaters Stream Team, Marine Biological Laboratory, Ipswich River Watershed Management Council, Executive Office of Environmental Affairs Ipswich River Watershed Team, Massachusetts Riverways Program, Quinebaug River 
Instream Flow Study, MADEP, and MADEM. We thank Massachusetts Division of Fisheries and Wildife (MDFW) and USGS personnel who provided field assistance, GIS support, technical and editorial review, and assisted in manuscript preparation. The cooperation of public and private landowners, who granted permission to access and sample the Ipswich River and its tributaries, is appreciated.

\section{RELATIONS AMONG STREAMFLOW, AQUATIC HABITAT, AND FISH COMMUNITIES}

Stream habitat is an important determinant of the distribution and abundance of fishes and aquatic invertebrates in streams (Stalnaker and others, 1995). In general, fish live where there is sufficient availability of suitable habitats to support their ecological and behavioral requirements (Matthews, 1998). Stream conditions such as water depth, current velocity, temperature, and water chemistry combine with stream substrate, woody debris, aquatic vegetation, and riparian vegetation to form a wide variety of habitats. Stream size, gradient, habitat complexity, and habitat sequencing also are important influences on the structure of stream fish assemblages (Gormans and Karr, 1978; Schlosser, 1995) and on the size and diversity of fish species. The abundance and diversity of fish species tends to increase downstream (Horowitz, 1978; Matthews, 1998). Headwater streams typically have mostly small fish and fewer species (Hubbs, 1987; Hagstrom and others, 1995). The fish communities of larger streams and rivers tend to be organized along a bank-midstream habitat orientation (Bain and others, 1988). For example, small fish that are distributed across riffle habitats in headwater streams tend to be restricted to the stream margins in larger streams because of higher midstream velocities and depths (Bain and others, 1988). Pool depth also is a strong indicator of fish size (Harvey and Stewart, 1991). Deep areas primarily are inhabited by older, larger fish; shallow habitat with low stream velocities is used primarily by small, young fish (Bain and others, 1988).

Riffles are the stream-habitat type most sensitive to flow fluctuations (Nehring, 1979). Sustained flow over riffles is important for maintaining macroinvertebrate communities, fish passage, spawning, egg incubation, feeding, and protective cover for fish (Espegren, 1996), and for maintaining dissolved oxygen levels in downstream reaches. Channel margins and other shallow areas also are among the first habitats to be affected by declining flows. Channel margins, woody debris, and submerged macrophytes provide primary habitats for macroinvertebrates (Maxted and others, 2000), which are the major food source for many freshwater fish. Shallow channel-margin habitat, therefore, is an important feeding, spawning, and nursery area (Panfil and Jacobson, 2000). In many streams the highest density of fish is found along shorelines in snags and vegetated edges (Lobb and Orth, 1991). Typically, young fish prefer emergent and submerged aquatic vegetation, backwaters, and channel-margin habitats for nursery areas; juveniles prefer channel margins for foraging and avoiding predation; and fish in adult life stages prefer pool, edgewater, and large woody-debris habitat (Lobb and Orth, 1991; Panfil and Jacobson, 2000). The availability of cover, structure, shade, and channel-margin habitat decreases substantially when water levels drop enough for the edge of water to recede from the bank. Loss of shore habitat can also cause fish to suffer increased predation from wading and diving birds, mammals, and other organisms.

Aquatic communities are adapted to tolerate a natural, summertime low-flow period. In Massachusetts, this low-flow period typically is between late July and mid-September. Streamflow during dry periods primarily is maintained by groundwater discharge, or base flow. A stream's base flow is related to the area and depth of aquifers contributing to the stream, and to the amount of withdrawals from the aquifers. Ground-water withdrawals can reduce base flow by intercepting ground water that would have flowed to the stream, or by inducing flow from the stream toward a pumped well. Withdrawals also can extend the duration of low-flow periods to the point where the modified conditions alter the long-term ecological integrity of aquatic ecosystems.

Low flows can have a major effect in structuring aquatic communities (Fausch and Bramblett, 1991, Poff and Ward, 1989). In general, the effect of low flows on fish populations begins with prolonged or recurrent flows below the 50 percent non-exceedence 
probability, becomes visible around the 25 percent nonexceedence probability, and acute around the 10 percent non-exceedence probability (Hickey and Diaz, 1999). As water levels drop, riffle habitats and fish passage are lost, flow becomes interrupted, and higher water temperatures and lower dissolved oxygen levels stress the aquatic community. Fish that did not move downstream remain temporarily in the disconnected pools for as long as conditions sustain their survivability. Not all fish species tolerate crowded conditions equally (Cortes and others, 1998). Small fish may not survive because of greater predation (Matthews, 1998), so the length of time an extreme low-flow or no-flow condition persists is critical (Matthews, 1998). Recovery of a reach after drying or extreme low flow depends on stream discharge, the depth and length of intervening riffles, the distance of the reach from a pool or impoundment that retains a full complement of species as potential colonists, and the relative colonizing ability of different species (Schlosser, 1995; Lonzarich and others, 1998). The persistence of species in intermittent streams depends upon their relative colonizing ability (Fausch and Bramblett, 1991). Upstream fish communities are characterized by species that are better adapted to colonizing streams following drought or flooding perturbations, whereas downstream communities are characterized by species that require more stable habitat conditions (Schlosser, 1982, 1987; Hansen and Ramm, 1994). Recovery of stream communities after rewetting is not immediate; rewatering alone does not provide all the components of a functioning stream ecosystem. For example, drying alters food availability by killing algae and macroinvertebrates.

One requirement for continued persistence of fish communities affected by periods of low flow or interrupted flow is the existence of downstream habitats such as deep pools, tributaries, spring holes, and other areas in which fish can take refuge and return upstream in wetter periods (Lonzarich and others, 1998; Matthews, 1998). Downstream impoundments may provide habitat that fish can move into during lowflow periods. In general, however, impoundments are detrimental to riverine species because they change stream habitat from a flowing habitat to a ponded habitat; this change causes a loss of riverine spawning and nursery areas. Streamflow below dams can be modified in flow duration and magnitude, water quality, water temperature, and sediment supply. Dams without adequate provisions for fish migration prevent access by resident fish to upstream and downstream habitat and spawning areas, and can threaten the persistence of anadromous fish communities.

The effects of reduced streamflows on aquatic life are not limited to loss of physical habitat. The thermal effects of drought can exceed the direct effect of low water (Matthews, 1998). Fish have characteristic thermal requirements for each of their life functions (such as feeding, spawning, growth, and metabolism), and some fish are less tolerant of heat stress than others. For example, the upper critical range of temperatures for brook trout is between 20 and $29^{\circ} \mathrm{C}$, whereas the upper critical range for some sunfish is 25 to $38^{\circ} \mathrm{C}$ (Elliott, 1994). Over time, increased stream temperatures could lead to thermal isolation of cold-water species, such as brook trout (Watson and others, 1998), and to expansion of the ranges of cool or warm-water species, such as redfin pickerel or pumpkinseed. In addition to increases in stream temperature caused by direct heating of reduced volumes of streamflow, ground-water withdrawals can cause the loss of coldwater springs that provide important areas of refuge during low-flow periods.

Flow alterations are one of the major stressors of aquatic systems. Prolonged periods of low flow and the consequent loss of stream-margin habitat can result in a simple community of mostly juvenile fish (Schlosser, 1987). The original fauna, with a mix of tolerant and intolerant fish species, are replaced by species that are tolerant of stressful physical conditions and able to reproduce even under adverse conditions (Matthews, 1998). In shallow reaches with low habitat volumes, the absence of deeper pool habitats needed to support older age classes and some pool-adapted species can lead to lower species richness and fish density (Schlosser, 1987). For example, when streamflow decreases, depth and velocity also decrease; these changes create conditions similar to those found in headwater reaches that favor small-stream species.

Rivers with highly altered and regulated flows can lose their ability to support natural processes and native species (Poff and others, 1997). Fish and other aquatic organisms require habitat features that cannot be maintained by minimum flows alone (Stalnaker, 
1990). A natural flow regime has a characteristic range and variability in the magnitude, frequency, duration, timing, and rate of change of flow. These variations in flow create and maintain a wide range of habitat features and regulate ecological processes in rivers that are critical to the native biodiversity and ecological integrity of rivers. High flows scour streambeds and banks, create and maintain bars and pool-riffle sequences, and import wood and organic matter from floodplains. High flows are important to both aquatic and riparian species; some fish use high spring flows and associated changes in water temperature as signals for migration or spawning, and seasonal access to floodplain wetlands is essential for survival of many species. Differences in tolerances of flooding duration by riparian plants, fish, and aquatic invertebrates allow some species to persist in locations from which they might otherwise be displaced by dominant but less tolerant species (Poff and others, 1997). Other species do better in dry years. The overall biological diversity and ecosystem integrity of a river benefits from variations in species success (Poff and others, 1997). Human alteration of flow regimes changes the pattern of natural hydrologic variation and disturbance, which alters habitat dynamics and creates conditions to which the native biota may be poorly adapted.

\section{HISTORICAL AND RECENT LOW FLOWS IN THE IPSWICH RIVER}

In 1997, American Rivers, an environmental organization, designated the Ipswich River as one of the 20 most threatened rivers in the United States, primarily because of low flows. A plot of the distribution of August mean flows for the period of record for selected southern New England gaging stations having 30 or more years of record (fig. 2) indicates that the Ipswich River has the lowest median August-mean flow, even among rivers whose basins also have substantial water withdrawals and development that affect streamflow, such as the Assabet, Charles, and Neponset Rivers.

\section{Historical Low-Flow Conditions}

Several reaches of the upper Ipswich River frequently are dry or have interrupted flow or extremely low flows. During a drought in 1934, Johnson and others (1934) reported the upper $9 \mathrm{mi}$ of the Ipswich River above the Middleton town line to have dried or had isolated stagnant pools of water for the last 2 weeks of August. In recent years, portions of the Ipswich River headwaters dried in 1993, 1995, and 1997 (Kerry Mackin, Ipswich River Watershed Association, oral commun., 1999). One of the most flowstressed reaches of the mainstem Ipswich River, as evidenced by fish kills and mussel die-offs in 1995, 1997, and 1999 (fig. 3), is downstream of the Reading, North Reading, and Wilmington well fields between I-93 and the confluence of Martins Brook with the Ipswich River. Other reaches that have had interrupted or extremely low flow include a reach of Maple Meadow Brook downstream of the Wilmington Well fields, and reaches of the Ipswich River downstream from the South Middleton Dam in Middleton and downstream of the Danvers well field in Middleton and Danvers (Kerry Mackin, Ipswich River Watershed Association, oral commun., 1999). The Danvers wells were not in regular production during the time of this study, but could return to operation in the near future.

\section{Recent Low-Flow Conditions}

At the beginning of the study, in June 1998, the Ipswich River Basin had a flood with a 7- to 10-year recurrence interval (Parker and others, 1998). Despite the wet beginning to the summer of 1998, parts of the Ipswich River were dry by mid-September of that year. During the summer of 1999 , large portions of the Ipswich River and its tributaries had extreme low flows or were dry. Hydrographs showing daily mean discharge for the Ipswich River gages during 1998-99 and median of daily mean discharge for the period of record are shown in figure 4. 


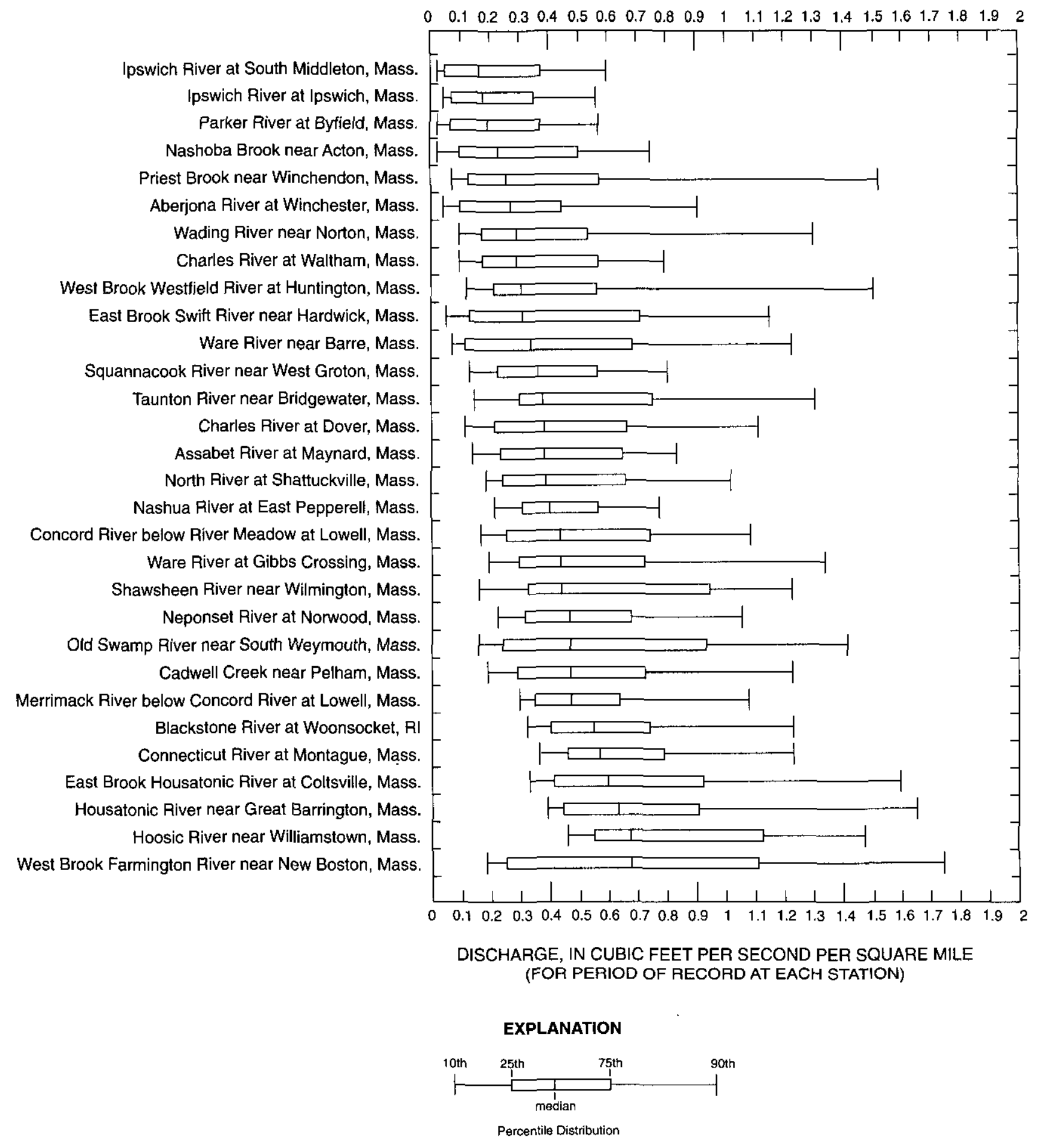

Figure 2. Distribution of monthly mean flow for August for 30 gaging stations in southern New England. 

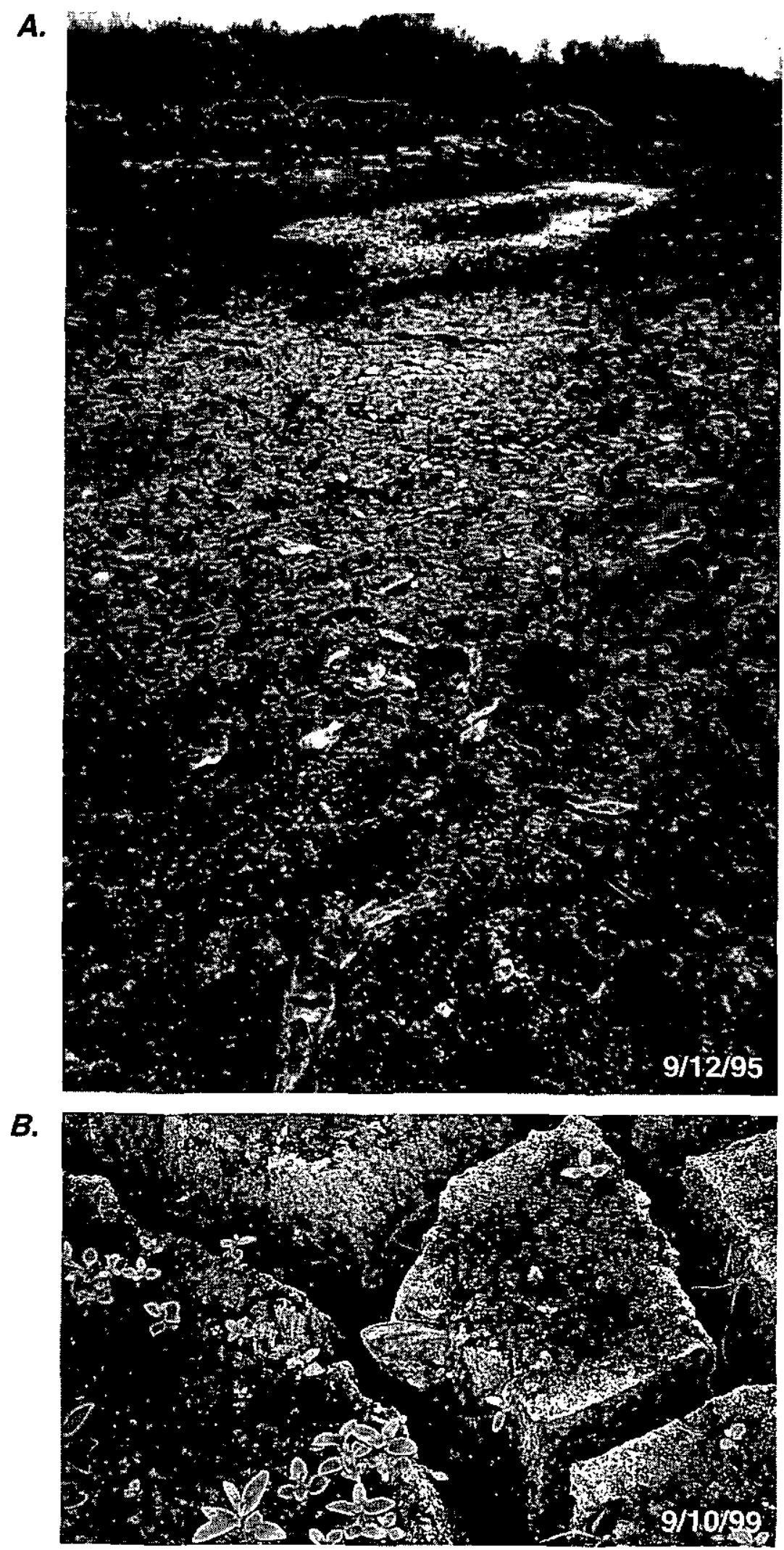

Figure 3. $(A)$ Fish kills and $(B)$ mussel die-offs in the Ipswich River, Massachusetts, 1995 and 1999. 
IPSWICH RIVER AT SOUTH MIDDLETON, MA 01101500

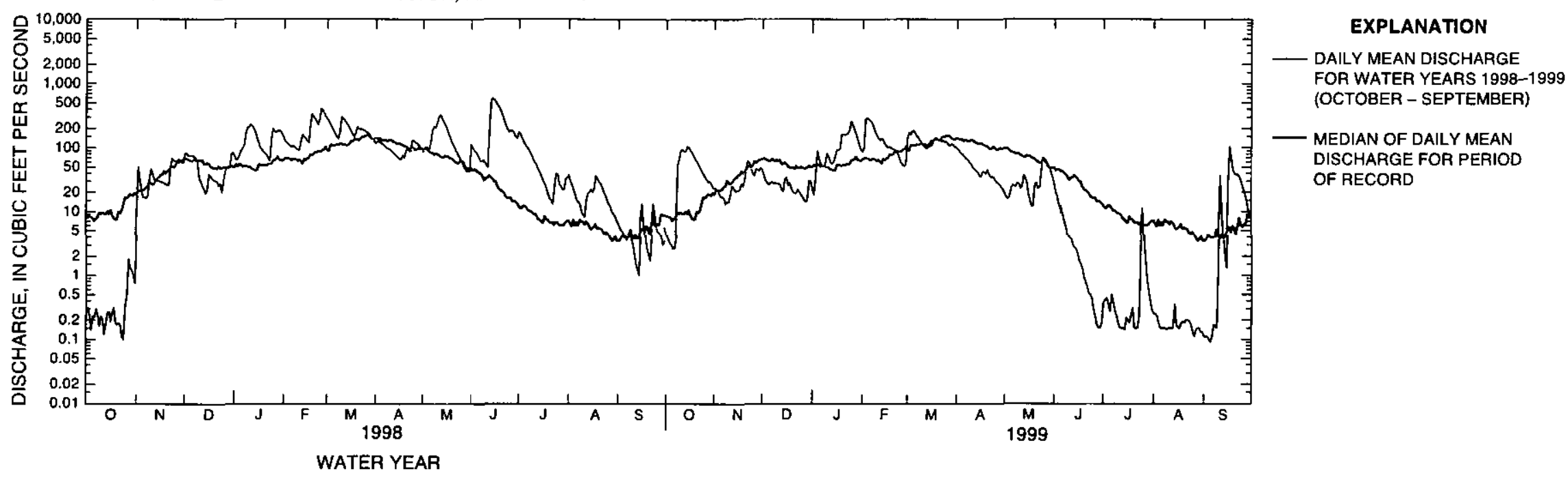

IPSWICH RIVER NEAR IPSWICH, MA 01102000

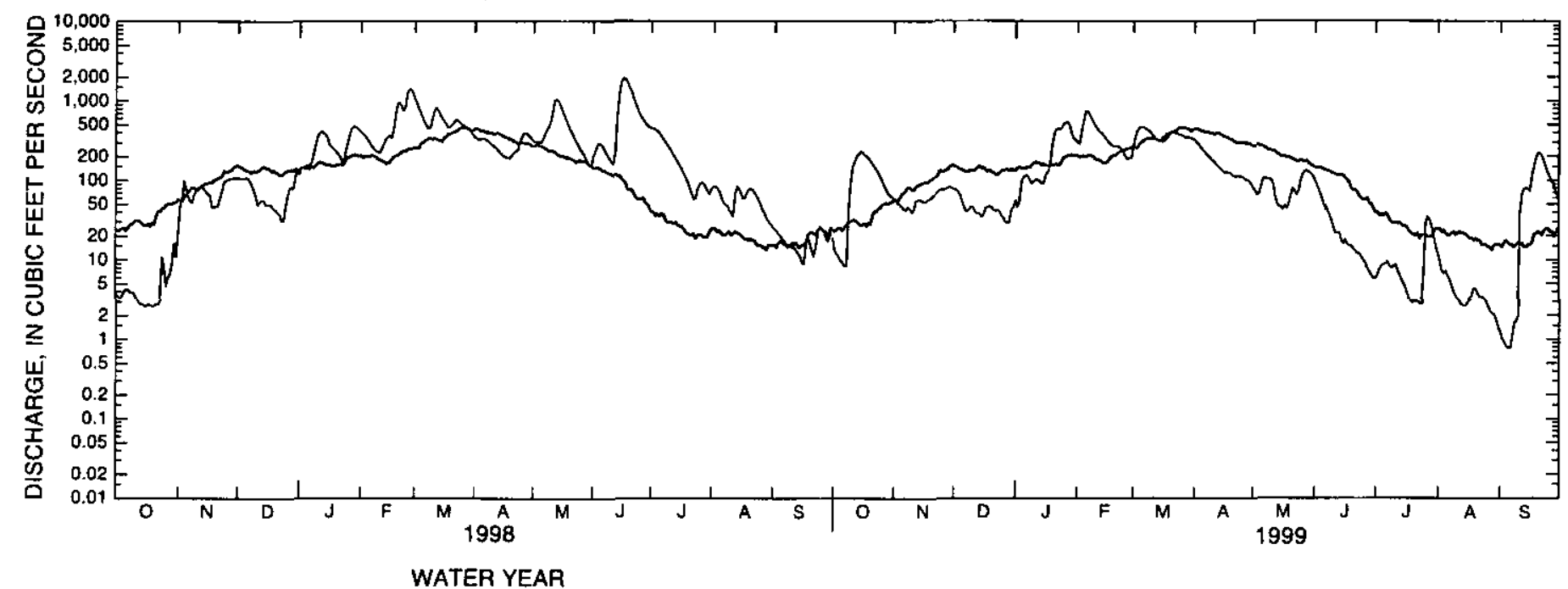

Figure 4. Daily mean discharge and median of daily mean discharge for period of record for ( $A$ ) South Middleton and ( $B$ ) Ipswich, Massachusetts, gaging stations, water years 1998-99. 
To represent the effects of recent withdrawal conditions on the magnitude and frequency of low flows, an HSPF model (Zarriello and Ries, 2000) was used to simulate flows for the 1961-95 period, with average 1989-93 withdrawals and 1991 land-use conditions. The 1-, 7-, and 30-day annual low flows were calculated from these simulated flows. From these $\mathrm{n}$-day annual low flow values a log-Pearson Type III distribution was used to calculate the magnitude of flow at different recurrence intervals. A recurrence interval of 2 years represents an every-other-year, or average, characteristic (half the years will be higher, half will be lower), and the value of discharge represents the mean annual value for that series (Emmett, 1975). Examination of the 2-year recurrence interval from the 1-, 7-, and 30-day low flows for the Ipswich River at the South Middleton gaging station (Zarriello and Ries, 2000), indicates that, under average 1989-93 water-withdrawal conditions, streamflow at the South Middleton gage was $0.7,0.9$, and $2.2 \mathrm{ft}^{3} / \mathrm{s}$, respectively (Zarriello and Ries, 2000).

During the last decade, increased withdrawals have resulted in near-zero flows at the South Middleton gage (Socolow and others, 1996; 1997; 1998; 1999; 2000) (table 1). In 4 of the past 5 years (ending in the 1999 water year $^{1}$ ), the 1-day and 7-day annual low flows have been considerably below the 0.7 and $0.9-\mathrm{ft}^{3} / \mathrm{s}, 2$-year recurrence probabilities, respectively. These low flows indicate that water demands above the South Middleton gage have increased since the 198993 period; therefore, stresses on aquatic habitat caused by low flows also have increased in recent years.

During 1998-99, the effects of declining streamflow were documented at various locations as part of this study. Streamflow in portions of the Ipswich River was interrupted during each year of the study. The riffle near Mill Street in North Reading/Reading went dry in September 1998. Dry weather conditions and withdrawals combined to create a major loss of habitat over
Table 1. One-day and 7-day annual low flows at the Ipswich River at South Middleton (01101500) gaging station, Middleton/Peabody, Massachusetts

\begin{tabular}{|c|c|c|c|}
\hline $\begin{array}{c}\text { 1-day annual } \\
\text { low flow } \\
\left(\mathrm{ft}^{3} / \mathrm{s}\right)\end{array}$ & Date & $\begin{array}{c}\text { 7-day annual } \\
\text { low flow } \\
\left(\mathrm{ft}^{3} / \mathrm{s}\right)\end{array}$ & Date \\
\hline 0.09 & $9-05-99$ & 0.11 & $8-31-99$ \\
\hline .10 & $10-24-97$ & .17 & $10-18-97$ \\
\hline .05 & $9-07-97$ & .08 & $9-15-97$ \\
\hline .09 & $10-01-95$ & 2.3 & $8-27-96$ \\
\hline .22 & $9-01-95$ & .23 & $9-01-95$ \\
\hline
\end{tabular}

much of the Ipswich River in the late summer of 1999. In 1999, the mainstem of the Ipswich River between I-93 and the confluence of Martins Brook was dry (figs. $5 A, B$ ), except for an isolated pool adjacent to Concord Street in North Reading/Reading (fig. 5C) and pools adjacent to the Mill Street Bridge (fig. $5 D$ ). The Ipswich also was dry between the South Middleton Dam and Russell Street in Middleton. Tributaries that went dry or almost dry in the late summer of 1999 included Maple Meadow Brook, Martins Brook, Idlewild Brook, Boston Brook, and Fish Brook. Streambeds were exposed in many headwater tributaries, in most riffles, and in reaches immediately downstream of dams and riffles, with the exception of a few isolated pools. Channel-margin features, such as exposed roots, undercut banks, woody debris, and overhanging vegetation, were unavailable in many other reaches. In many reaches that did not dry completely, flow velocities were undetectable, and some reaches generated algal blooms or became covered with duckweed. The water trapped in these stagnant reaches also likely was characterized by elevated temperatures and severely depleted levels of dissolved oxygen, but these properties were not measured.

\footnotetext{
${ }^{1}$ A water year is the 12 -month period beginning October 1 and ending September 30 . It is designated by the calendar year in which it ends.
} 
A.

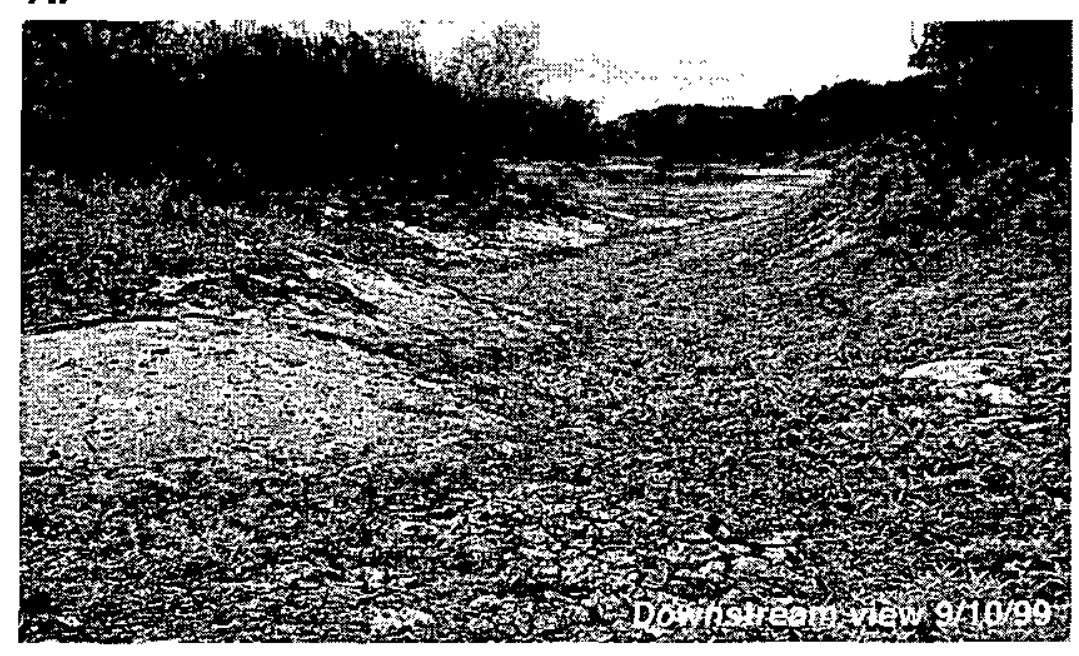

B.

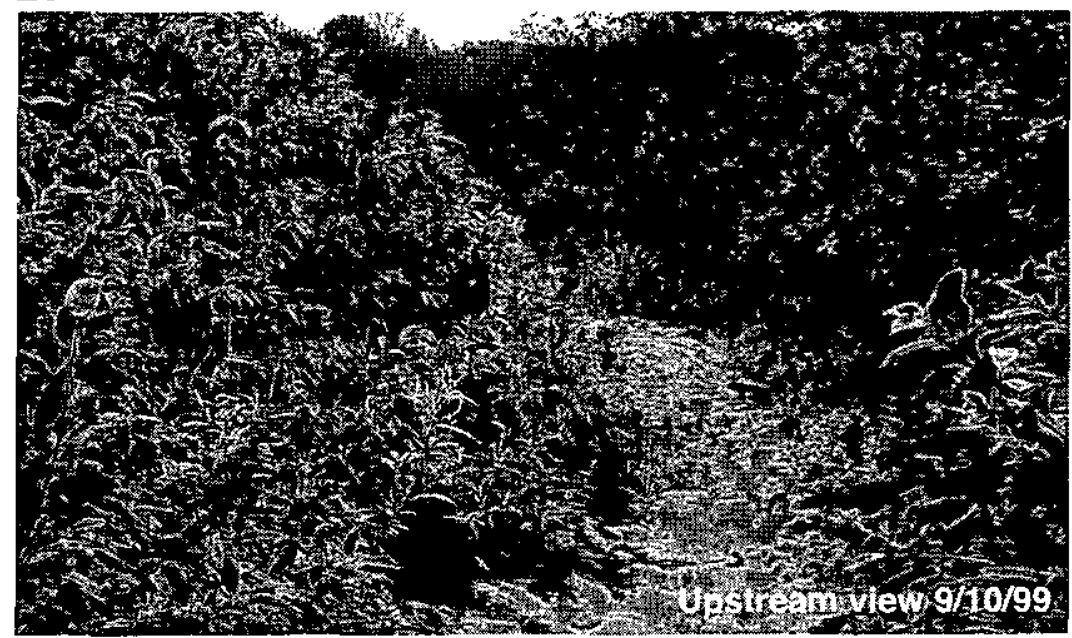

c.

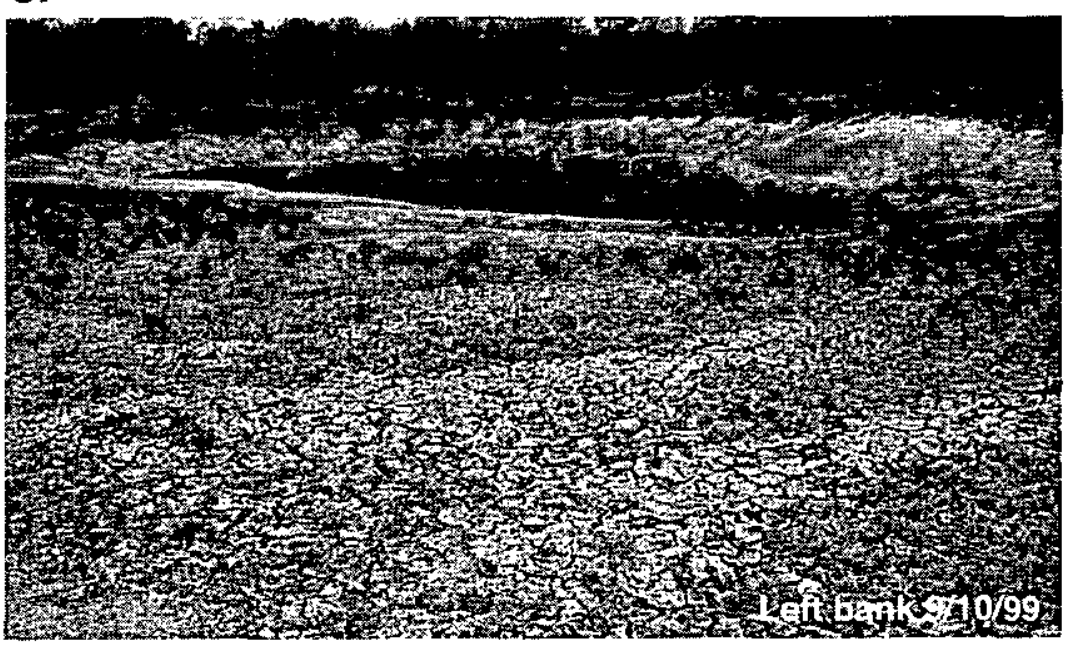

D.

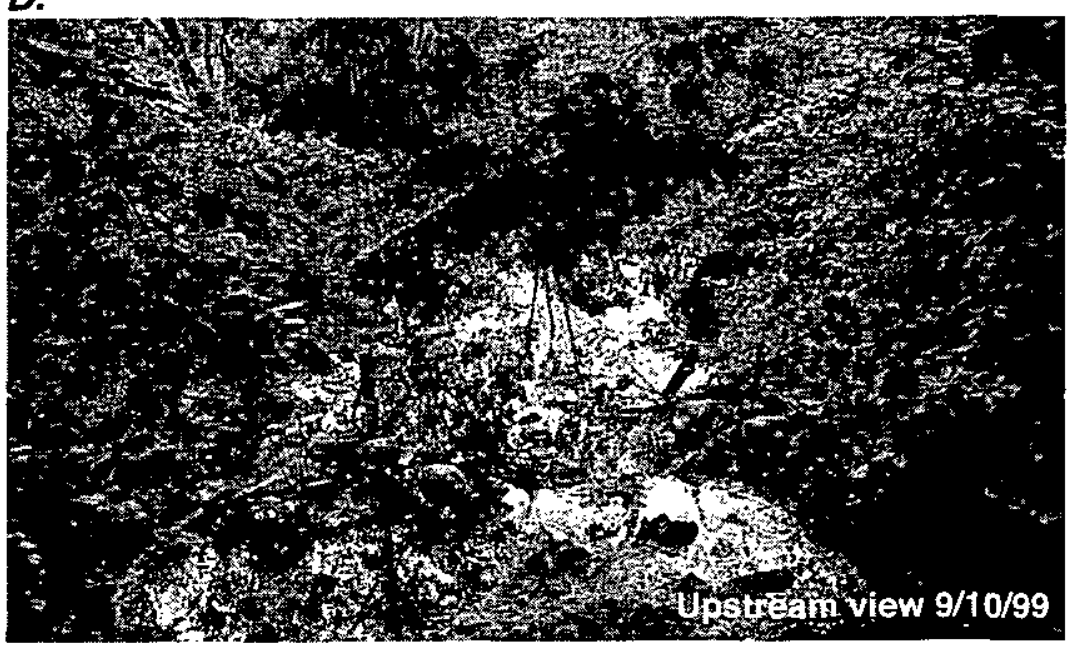

Figure 5. Stream habitats on the mainstem Ipswich River, Massachusetts, during low-flow conditions, 1999. (A) Dry streambed downstream of I-93, North Reading/Reading, downstream view; (B) Dry streambed, North Reading/Reading, upstream view; $(C)$ Isolated pool downstream of I-93 North

Reading/Reading, view of left bank; $(D)$ Isolated pool upstream of Mill Street, North Reading/Reading, upstream view. 


\section{HISTORICAL FISH COMMUNITIES IN THE IPSWICH RIVER}

Pre-colonial fish communities of the Ipswich River are difficult to describe because no records are available. Freshwater fish communities likely were altered early in colonial times by construction of many small dams for water-powered mills, and by clearing of the land. Various reports describe the composition of the inland freshwater fish community in the mainstem of the Ipswich River early in the 20th century.

Although substantial land-use and stream-channel alterations predate historical fish assessments, these records lend some insight into past effects of habitat and flow alterations on fish communities. Dow (1926) reports that perch, sunfish, bullhead, and eels were caught below the Willowdale Dam in Ipswich. Johnson and others (1934) report that the lower reaches of the mainstem contained mostly pond fish, such as largeand small-mouth bass, calico bass (crappie), and perch; pickerel are reported throughout the river, and only one trout pool "of repute" is reported in the headwaters of the mainstem. Historical fish communities in the tributaries are not well documented, but it is likely that several tributaries supported cold-water fisheries. Johnson and others (1934) report the presence of brook trout and dace in tributary streams.

A major difference between the current fish community in the Ipswich River and the historical fish community is that the historical fish community also would have included anadromous fish species for a portion of the year. Anadromous species that have been documented to be present in the Ipswich River in large numbers include alewife (Alosa pseudoharengus) and blueback herring (Alosa aestivalis) (Belding, 1921). Although their presence is less well documented, the anadromous fish community probably also included Atlantic salmon (Salmo salar), Atlantic sturgeon (Acipenser oxyrhynchus), American shad (Alosa sapidissma), rainbow smelt (Osmerus mordax), white perch (Morone americana), and sea-run brook trout (Salvelinus fontinalis) (Felt, 1834; Belding, 1921). Historical reports document that herring runs extended into Middleton (Belding, 1921), but declined in the 1800 s for reasons given by Belding (1921) as "(1) the utilization of the spawning grounds for water supplies, (2) the obstruction of the stream by dams without fishways, (3) the trade-waste pollution, and (4) the diminution of the quantity of water in the Ipswich and its tributaries."

Herring and other anadromous fish historically would have composed a major component of the food chain in portions of the Ipswich River. Herring spawn in early spring. Adult herring return to the ocean after spawning, but young-of-the-year (YOY) remain in the river until fall, when they migrate out to sea. During their spawning run, adult herring would have provided other important functions; filter-feeding adult herring have been documented to reduce phytoplankton and zooplankton in freshwater, and adult herring that die during spawning runs return nutrients to river systems (Phillips Brady, Massachusetts Department of Marine Fisheries, oral commun., 2000). Within the last decade, efforts to restore herring runs in the Ipswich River have been made by reconstructing a fish ladder at the Sylvania Dam, and stocking the river with herring from the nearby Charles River by the Massachusetts Division of Marine Fisheries.

\section{METHODS}

The determination of appropriate streamflow requirements for the protection of stream habitat and stream health depends upon knowledge of the relations between streamflow and habitat availability. Habitat assessments provide information about the limiting factors that affect aquatic biological communities (Fitzpatrick and others, 1998), the appropriate scales of measurement for study (Kershner and Snider, 1992), and appropriate locations for study sites. An evaluation of habitat quality is critical to any assessment of ecological integrity (Barbour and others, 1999). Habitat assessments, however, need to be complemented with biological monitoring to describe adequately the health of a stream ecosystem (Karr and Chu, 1999). These considerations were a component of this study and are described below. 


\section{Habitat Assessment}

A reconnaissance of the mainstem of the Ipswich River was conducted to identify and delineate stream macrohabitat, and to determine accessibility to reaches selected for sampling. Four study sites critical for habitat purposes were identified for inclusion in the Ipswich HSPF model (Zarriello and Ries, 2000). These sites were among the first to dry or to develop fish-passage problems. Stream reaches were rated for habitat quality by use of Rapid Bioassessment Protocols (RBP) developed by the U.S. Environmental Protection Agency (USEPA) (Barbour and others, 1999). Physical stream habitat also was characterized by use of transect-based methods (Simonson and others, 1993, Fitzpatrick and others, 1998).

\section{Macrohabitat Delineation}

Habitat delineations initially were made by use of topographic and georeferenced orthophoto maps, on which the stream centerline had been marked in meters. These habitat delineations later were refined on the basis of field observations made during reconnaissance float trips. Aquatic habitats in the mainstem of the Ipswich were classified by stream size [(small streams (1st, 2d, and 3d order), and medium streams (4th and 5th order)], gradient (high gradient, low gradient), habitat characteristics (water velocity, depth, substrate, and cover), and geomorphic channel units (riffle, run, glide, pool, and impoundment). These assessment criteria have proved useful for classifying fish assemblages (Bain and Knight, 1996; Bain and Stevenson, 1999).

Reaches were classified as riffles, runs, glides, pools, or impoundments. Riffles have fast flow velocities, shallow water depths, coarse-grained substrates (gravel, cobble, boulder), and turbulent surface flows that commonly contain small standing waves or white water. Runs have moderate flow velocities and depths, a variety of substrates (sand, gravel), and somewhat turbulent but unbroken surfaces. Glides have slow, steady current, smooth surfaces, moderate depths, and fine-grained substrates (sand, silt, organic detritus). Pools generally have deeper water than glides, finegrained substrates (sand, silt, organic detritus), and currents that are barely detectable or do not show at the surface. Impoundments are large pools behind dams or beaver dams.

Some reaches can be classified differently at different discharges (flows). At high flows, the percentage of river classified as runs increases. Riffles can become runs as riffle controls are submerged, and glides and pools can become runs as velocity increases. At low flows, the percentage of river classified as runs decreases. Runs can become glides as velocity decreases, and runs can become riffles as stream substrate becomes exposed. During this study, most reaches were visited only once during moderate to low flows.

Limited time and resources precluded the mapping of individual geomorphic channel units. Instead, riffle-and-run habitats, and glide-and-pool habitats were grouped and mapped as macrohabitats. Macrohabitats that represented the range of habitat types in the basin were delineated to identify reaches for habitat and fish sampling. Study reaches were distributed throughout the entire length of the mainstem. Study reaches also were established in selected tributaries so that tributary fish communities could be compared to those of the mainstem to assess the availability of tributaries as areas of refuge during extreme low flow.

\section{Habitat Quality}

USEPA rapid bioassessment protocols (RBP) (Barbour and others, 1999) were used to evaluate stream-habitat quality within each study reach. Habitat assessments were completed for all sites by use of USEPA RBP habitat-assessment field-data sheets for low-gradient streams, except for the longer riffle reaches, which were assessed by use of high-gradient stream assessment criteria (Barbour and others, 1999). Habitat assessments were completed during the same time as fish sampling.

Stream-habitat quality is scored by visually assessing the stream's physical environment by use of 10 metrics that rate general categories of stream habitat: available cover, channel substrate, pool variability, sediment deposition, channel-flow status, channel alteration, channel sinuosity, bank stability, bankvegetation protection, and riparian-zone width. Each 
metric is scored numerically between 0 and 20 ; scores between 0 and 5 are considered poor habitat, 6 and 10 marginal habitat, 11 and 15 suboptimal, and 16 to 20 as optimal habitat. The scores for available cover, velocity/depth regime, and channel-flow status can score differently depending on the flow at the time the survey is made; therefore, thirty percent of the total score is related to streamflow. Because a portion of the total score reflects features independent of flow, such as the width of the riparian zone, the minimum scores are never zero, even if the river has no flow or is dry.

\section{Physical Habitat Survey}

Physical habitat was characterized by use of transect-based methods (Simonson and others, 1993; Fitzpatrick and others, 1998). Time and resources, however, limited the number of transects to one per study reach. Transects were located at sites that best represented average conditions within the study reach. Physical habitat features measured at each transect were chosen to represent a reach two channel widths long, centered on a representative cross section. Each cross section was measured at about 20 or more intervals across the channel. Depths below water surface were measured with a folding engineer's rule to the nearest $0.1 \mathrm{ft}$. Velocities were measured with a Standard AA or pygmy current meter (Rantz and others, 1982). Distances to features above the water surface were measured to the nearest $0.5 \mathrm{ft}$ with a range pole. Physical habitat features that exhibited variability across the channel, such as substrate type, were measured at three equally spaced points across each cross section (left side, center, right side). Criteria for measurement of physical habitat features are given in table 2. Physical habitat assessments were completed at the time of fish sampling, or as much as a day before or after fish sampling, at a similar flow.

\section{Fish-Community Assessment}

Biological monitoring in this study targeted fish because they are long-lived, sensitive to a wide range of stresses, and can be assigned an economic and societal value (Fausch and others, 1990). In comparison to macroinvertebrates, fish are easy to identify, and the relations between fish and stream health are better understood and valued by the public. In addition, minimum flows adequate to maintain fisheries also tend to be sufficient to maintain macroinvertebrates and other aquatic life, recreational uses and aesthetic qualities. A drawback of using fish to indicate flow degradation is that fish integrate the effects of many stresses, so it is difficult to determine the effect of each stress.

Assessment of fish communities was designed to characterize fish species diversity, relative abundance, and length-frequency distribution of fish in the mainstem of the Ipswich River and its tributaries. Fish were sampled during summer periods of low to moderate streamflow, because fish assemblages during summer are relatively stable and contain the full range of resident species (Gibson and others, 1996), and because staff are available, weather conditions are good, and safety and sampling efficiency are maximized.

\section{Fish-Community Sampling}

Sampling reaches were distributed over the length of the mainstem and major tributaries, and were chosen to represent the range of habitat types. Sampling reaches included $100 \mathrm{~m}$ of stream length, where possible. The reaches were marked with surveying ribbon and located with a Global Positioning System (GPS), or were recorded on USGS 1:25,000 topographic maps and georeferenced orthophotographs that were marked in meters above the river mouth.

Fish were sampled primarily by electrofishing with pulsed direct current (DC) backpack units (fig. 6). Backpack shockers are best used in small or shallow streams and were appropriate for sampling most reaches of the Ipswich River and its tributaries during summer low flows, with the exception of impoundments, flow-through ponds, and some of the deeper pools. Backpack sampling consisted of a single upstream pass by a team of three to five people, without block nets. This approach has been shown to give a representative sample of the fish assemblage (Simonson and Lyons, 1995). All portions of the stream were sampled, including habitat features such as woody debris, submerged aquatic vegetation, undercut banks, and overhanging vegetation. Dipnets were used to capture all fish. Fish were kept alive in 5-gal buckets, or portable livewells, before being identified, counted, measured, and released. 
Table 2. Criteria for measurement of physical habitat features

[ft, foot; ft/s, foot per second; mm, millimeter; $>$, actual value is greater than value shown; <, actual value is less than value shown]

Physical habitat feature Description

\section{Physical data}

Bankfull width (ft)

Distance along a cross-section, measured perpendicular to streamflow, from bankfull indicator (top of bar, upper extent of erosion, lower extent of terrestrial vegetation, high water marks, and others), at top of bank to a point of equal height on opposite bank, to nearest $0.1 \mathrm{ft}$.

Channel width $(\mathrm{ft})$

Distance along a cross-section, measured perpendicular to streamflow, from left edge of water to right edge of water, to nearest $0.1 \mathrm{ft}$.

Cross section depth $(\mathrm{ft})$

Vertical distance from water surface to stream bottom; measured at about 20 intervals including breaks in slope in the streambed, to nearest $0.1 \mathrm{ft}$. Points above water surface or in dry channel measured as vertical distance down from bankfull indicator, to nearest $0.5 \mathrm{ft}$.

Thalweg depth $(\mathrm{ft})$

Lowest cross section depth or point of zero flow. Measured in dry channel as vertical distance down from bankfull indicator, to nearest $0.5 \mathrm{ft}$.

Velocity $(\mathrm{ft} / \mathrm{s})$

Streamflow rate measured in thalweg with a standard AA or Pygmy current meter at $0.6 \mathrm{ft}$ or 0.2 and $0.8 \mathrm{ft}$ of depth, depending on depth.

Substrate type (percent)

Streambed material measured at 3 equally spaced points along the cross section; each category visually estimated to nearest 5 percent; particle diameters in each category are as follows:

Coarse inorganic substrate

Bedrock

boulder: $>256 \mathrm{~mm}$

cobble: $\quad 64-256 \mathrm{~mm}$

gravel: $\quad 2-64 \mathrm{~mm}$

Finer inorganic substrate

sand: $\quad 0.0625-2 \mathrm{~mm}$

silt/clay: $\quad<0.0625 \mathrm{~mm}$

Organic substrate

Coarse particulate organic matter (CPOM); roots, branches, twigs

Fine pariculate organic matter (FPOM); leafs, detritus, muck

Other; mud, peat, marl

Cover (percent)

Any feature that provides cover for fish; visually estimated along the transect, to nearest 5 percent. Categories are:

Hard, more durable structures

Large woody debris; log jams, trees, large branches, root wads

Rock structure; cobbles, boulders

Artificial; walls, bridges

Soft, transient structures and aquatic vegetation

Small woody debris; sticks, twigs, leaves, detritus

Emergent vegetation

Floating vegetation

Submerged vegetation

Aquatic moss

Bank cover-must be within $1 \mathrm{ft}$ of the water surface

Overhanging vegetation

Exposed roots

Undercut banks

Rock, Riprap 
Table 2. Criteria for measurement of physical habitat features—Continued

\begin{tabular}{|c|c|}
\hline Physical habitat feature & Description \\
\hline \multicolumn{2}{|r|}{ Physical data-Continued } \\
\hline Cover (percent)—Continued .............. & $\begin{array}{l}\text { Hydraulic habitat characteristics } \\
\text { Tributary } \\
\text { Oxbow, side channel, overbank } \\
\text { Eddies, varied flow } \\
\text { Riffled surface } \\
\text { Deep pool }\end{array}$ \\
\hline Heterogeneity ..................................... & Degree of variety of cover types; visually estimated to category; heterogenous, mix, homogeneous. \\
\hline 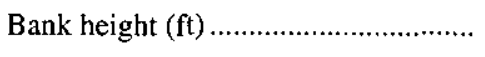 & Vertical distance along cross section from bankfull indicator to bottom of bank, to nearest $0.5 \mathrm{ft}$. \\
\hline 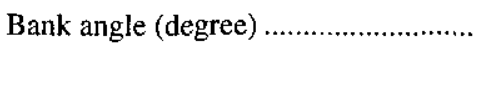 & $\begin{array}{l}\text { Angle of the streambank along a transect, from the top of the streambank to the bottom of the } \\
\text { streambank, to nearest } 5 \text { degrees. }\end{array}$ \\
\hline Bank composition ................................ & $\begin{array}{l}\text { Composition of bank within the transect, visually estimated in order of the three dominant substrate } \\
\text { types: bedrock, boulder, cobble, gravel, sand, silt, clay, soil, organic soil/peat, artificial. }\end{array}$ \\
\hline Vegetation density .................................... & Density of vegetation visually estimated along the transect for each bank, to nearest 25 percent. \\
\hline Vegetation type & $\begin{array}{l}\text { Composition of riparian vegetation, along the transect, visually defined as either upland or wetland, } \\
\text { with further classification as: forest, forest/shrub, shrub, shrub/herbaceous, herbaceous or } \\
\text { emergent, to nearest } 5 \text { percent. }\end{array}$ \\
\hline 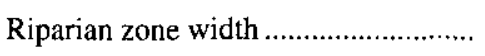 & Horizontal distance along cross section. \\
\hline .................... & Proportion of the transect estimated visually as: fully shaded, partially shaded, or open. \\
\hline
\end{tabular}

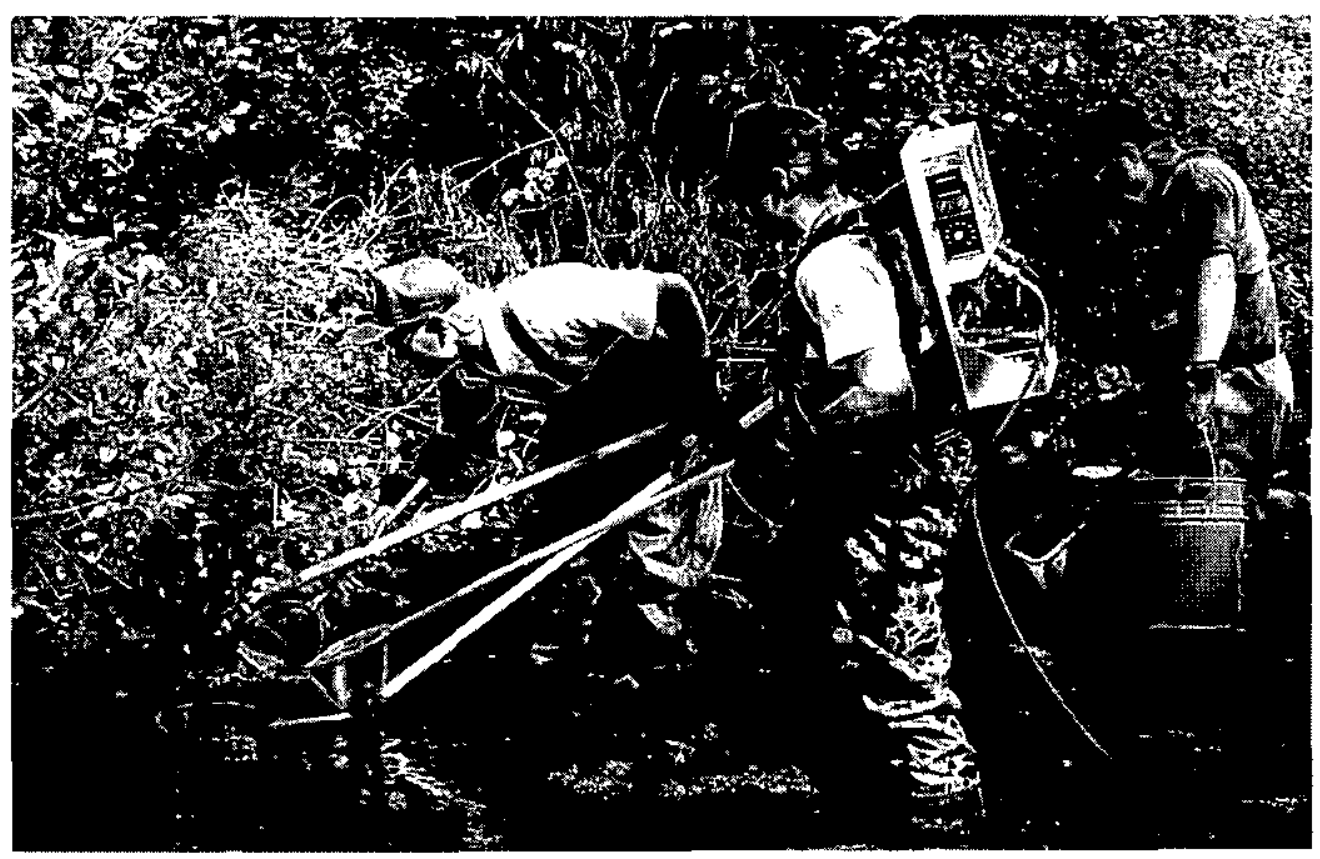

Figure 6. Massachusetts Division of Fisheries and Wildlife personnel backpack electrofishing on the Ipswich River, Massachusetts. 
Stream reaches that were too deep to wade, or where more power output for shocking was required, were sampled with a boat-operated electrofishing unit and gill nets. During boat electrofishing, crews of three to five people sampled shoreline areas by making a single pass with an electrofishing boat. All fish were collected and placed into the boat livewell before being identified, counted, measured, and released. Gillnets were set across the waterbody transverse to the direction of flow. The gillnets are $150 \mathrm{ft}$ long and consist of five panels of different mesh size ( 0.75 to $1.5 \mathrm{in}$.), and are designed with a floating top line and a sinking leadcore bottom line so the net will remain upright under water and maintain contact with bottom substrate during sampling. Nets were set for a minimum of 2 hours, and a maximum of 5 hours. Fish collected by gillnets commonly suffer higher mortality rates than those electrofished; those that were in good condition were returned to the water after being identified, counted, and measured; those that were not in a suitable condition to be returned to the water were removed and disposed of properly.

Captured fish were identified with respect to species, measured for total length, counted, and released. The first 100 fish of each species were measured to the nearest millimeter for length-frequency analysis, with the exception of American eels (Anguilla rostata) and sea lampreys (Petromyzon marinus), which were measured to the nearest centimeter. If more than 100 fish of a species were captured, these were tallied in the species count, but no lengths were recorded. Two percent or no fewer than two individuals (or one if only a single specimen was collected) of each species captured were preserved in 10-percent formalin for confirmation of identification by laboratory analysis (known as a voucher sample), and archived in a MDFW reference collection.

Field records included sample date, stream name, town name, site description, length of sampling reach, and sampling gear type. Information on electrofishing equipment and use also was recorded, including backpack and battery identification numbers, number of amperes and volts used, pulse frequency and width settings, and electrofishing effort (the actual time that current is sent through the water). The latter was recorded to enable standardization and comparison of results based on Catch per Unit Effort (CPUE). Flows at the Ipswich gaging station were recorded as a reference of the hydrological conditions during the sampling period. Other observations, such as air and water temperatures, water clarity, and general weather conditions were made to determine the adequacy of the sample.

\section{Index of Biotic Integrity}

Fish-collection data were used to assess the biological integrity of the Ipswich River. Biological integrity is the capability to support and maintain a balanced, integrated, adaptive community of organisms having a species composition, diversity, and functional organization comparable to that of the natural habitat of the region (Karr and Dudley, 1981). The Index of Biotic Integrity (IBI), originally developed to assess the biological quality of small- to medium-sized warmwater streams in the midwestern United States, uses a multimetric approach for measuring biologic condition (Karr, 1981). The IBI developed by Karr (1981) contains 12 metrics grouped into 3 classes: species richness and composition, trophic composition, and abundance and condition (table 3 ).

Species richness is the total number of species found at a particular locality. In general, the more degraded the stream, the lower the number of resident fish species (Halliwell and others, 1999). Because tolerant species tend to increase under degraded conditions, a high proportion of tolerant species can indicate a stressed environment and reflect lower biotic integrity (Simon and Lyons, 1995). Comparison to the species richness of a reference site can serve as a measure of the change in ecological condition. Trophic composition is the proportion of a fish community classified by feeding category or habitat type from which the food is taken. An increase in the proportion of specialist feeders that forage in restricted habitats is hypothesized to correlate with increased biotic integrity, whereas an increase in the proportion of generalist feeders that consume a wide variety of food types and exploit a wide range of habitats is considered to correlate with a decrease in biotic integrity (Halliwell and others, 1999). Fish abundance is a measure of the ability of a stream to support an aquatic community (Goldstein and others, 1994). In general, degraded sites would be expected to have reduced numbers of lotic (river) residents and increased numbers of lentic (pond) individuals. 
Table 3. Index of Biotic Integrity Metrics

[Source: Karr, 1981]

\begin{tabular}{|c|c|}
\hline Category & Metric \\
\hline Species richness and composition .......................... & $\begin{array}{l}\text { Total number of fish species } \\
\text { Number and identity of darter species } \\
\text { Number and identity of sunfish species } \\
\text { Number and identity of sucker species } \\
\text { Number and identity of intolerant species } \\
\text { Proportion of individuals as green sunfish (tolerant species) }\end{array}$ \\
\hline 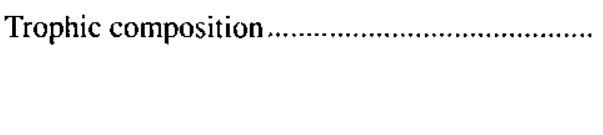 & $\begin{array}{l}\text { Proportion of individuals as omnivores } \\
\text { Proportion of individuals as insectivorous cyprinids (minnows) } \\
\text { Proportion of individuals as top carnivores }\end{array}$ \\
\hline 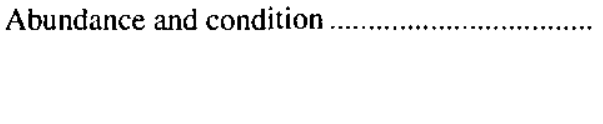 & $\begin{array}{l}\text { Number of individuals in sample } \\
\text { Proportion of individuals as hybrids } \\
\text { Proportion of individuals with disease, tumors, fin damage, or skeletal anomalies }\end{array}$ \\
\hline
\end{tabular}

The IBI score for a given reach is the sum of the metric scores; each metric is assigned a score of 1 (worst), 3, or 5 (best); 5 points are given if the fish community under investigation is similar to an unaltered reference fish community, 1 point if the fish community departs considerably from the reference condition, and 3 points for an intermediate value. The total score for the original version of the IBI (Karr, 1981) ranged from 60 (best) to 12 (worst); however, this scoring range may differ for different IBIs. IBI metrics must be replaced or modified in the number, identity, and scoring of metrics to adapt the index to the different resident fish assemblages and habitat types found in streams in different regions and of different sizes and thermal regimes (Simon and Lyons, 1995, Simon, 1999). In the Northeast, it is important to account for low species richness, introduced fish species, and a high proportion of generalist feeders (Halliwell and others, 1999). The IBIs used in this study were designed for use in different areas of New England, including small cold-water streams in Connecticut (Jacobson, 1994), and small cold-water and mixed-water streams in Vermont (Richard Langdon, Vermont Department of Environmental Conservation, written commun., 1999).

\section{Development of a Target Fish Community}

The USGS currently is developing a method to define a healthy freshwater fish community appropriate for a natural river in southern New England (M.B.
Bain, U.S. Geological Survey, written commun., 2000). This fish-community composition will serve as a target for river enhancements in the Quinebaug River, Mass., and as an endpoint for evaluating restoration progress. This model fish community also may be used as an indicator of the freshwater fish-community composition that may be supported were flows restored in the Ipswich River. A target fish community specific for the Ipswich River is currently under development (Vernon Lang, U.S. Fish and Wildlife Service, written commun., 2001).

Development of the target fish community for the Quinebaug River required determination of a comprehensive list of potential species from historical accounts. The species list was refined for restricted distributions, failed introductions, and recent occurrences, and was restricted to freshwater species. To develop a target fish community, six reference rivers were identified in Massachusetts and Connecticut (Ware, Housatonic, Fivemile, Natchaug, Scantic, and Willimantic), and available fish data from the reference rivers were obtained. The numbers of fish were tallied by species, and the proportion of total individuals by species was obtained by dividing the number of fish of a given species by the total number of individuals. A ranking procedure was used to exclude non-native fish. Species habitat requirements were summarized into three macrohabitat classes on the basis of their habitat use: macrohabitat generalists (MG), fluvial dependents (FD), and fluvial specialists (FS) (Bain and Knight, 1996). Macrohabitat generalists, such as redfin pickeral, are fish species and size classes that use a broad 
range of habitat; they include species that commonly are found in lakes, reservoirs, and streams, and are able to complete their life cycle in any of these systems. Fluvial specialists, such as brook trout, are fish species that almost always are reported as present in streams or rivers, and that require flowing-water habitats throughout life. Fluvial dependents, such as white suckers, are species that require access to streams or flowing-water habitats for a specific life stage, but otherwise commonly are found in lakes and reservoirs (Bain and Travnichek, 1996).

A modification of habitat classifications (the New England classification system) was developed by Bain (M.B. Bain, U.S. Geological Survey, written commun., 2000) to accommodate regional differences in habitat requirements. Habitat classifications for four species (fallfish, creekchub suckers, long-nose dace, brook trout) were changed from macrohabitat generalists to fluvial dependents or fluvial specialists. American eel, a catadromous fish that requires access to stream habitats for a portion of its life cycle, was classified as a macrohabitat generalist for the purposes of this report because it occupies a wide range of habitats during the portion of its life cycle that it lives in freshwater streams. Sea lamprey, an anadromous fish that also requires access to stream habitats for a portion of its life cycle, had not been definitively categorized at the time of this study, and had a very small sample size; therefore, it was not included in the fish-community analysis.

\section{Streamflow Requirements for Habitat Protection}

Various methods have been developed to determine streamflows that can be used as minimum flow requirements for protection of aquatic habitat. Five methods that have been applied widely were selected for comparison in this report. These methods include the

1. Tennant Method (Tennant, 1976).

2. New England Aquatic Base-Flow (ABF) Method (U.S. Fish and Wildlife Service, 1981; Lang, 1999).

3. Wetted-Perimeter Method (Nelsen, 1984; Leathe and Nelson, 1986).

4. R2Cross Method (Espegren, 1996; 1998).

5. Range of Variability Approach (RVA) (Richter and others, 1996).
For this study, streamflow requirements were determined with the Tennant, ABF, and RVA methods calculated from daily discharges obtained for the 1961-95 period with a basin-scale precipitation-runoff model of the Ipswich River (Zarriello and Ries, 2000), for a simulation representing no withdrawals and 1991 land use. For purposes of comparison, streamflow requirements also were determined for a simulation representing current conditions with 1989-93 withdrawals and 1991 land use.

Streamflow requirements determined from the various methods are compared to streamflow values developed on the basis of commonly calculated flow statistics, such as the 70-, 80-, and 90-percent exceedence flow durations, and the 7-day, 10-year low flow (7Q10).

\section{Tennant Method}

The Tennant method bases its streamflow requirements on the observation that aquatic habitat conditions are similar in streams carrying the same proportion of the mean annual flow (QMA) (Karim and others, 1995). The method divides a year into a winterflow period (October-March) and a summer-flow period (April-September), establishes streamflow requirements for each period by means of a predetermined percentage of the mean annual flow (Tennant, 1976), and associates aquatic habitat conditions with different percentages of mean annual flow (table 4).

Minimum streamflows for small streams during summer commonly are established by the Tennant method by use of the 40-, 30-, and 10-percent QMA (Annear and Conder, 1984), which represent good, fair, and poor habitat conditions, respectively, according to Tennant (1976). In general, at 30 percent of the QMA, most of the stream substrate is submerged, but at 10 percent of the QMA half or more of the stream substrate is exposed (Tennant, 1976). The Canadian Atlantic Provinces method designates 25 percent of the $\mathrm{Q}_{\mathrm{MA}}$ as the minimum streamflow requirement (Dunbar and others, 1998).

The Tennant method is best applied to gaged, unregulated streams. The method should not be applied to regulated streams because the mean annual flow value calculated for regulated streams may not include water that has been withdrawn and not returned to the river. 
Table 4. Relations between aquatic habitat condition and mean annual flow described by the Tennant method for small streams

[Source: Tennant, 1976. QMA, mean annual flow; <, less than]

\begin{tabular}{|c|c|c|}
\hline $\begin{array}{l}\text { Aquatic habitat } \\
\text { condition for } \\
\text { small streams }\end{array}$ & $\begin{array}{c}\text { Percentage of } \\
\mathbf{Q}_{M A_{1}} \\
\text { April-September }\end{array}$ & $\begin{array}{c}\text { Percentage of } \\
\text { OMA, }_{\text {, }} \\
\text { October-March }\end{array}$ \\
\hline 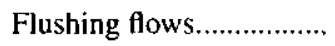 & 200 & 200 \\
\hline Optimum range ................... & $60-100$ & $60-100$ \\
\hline 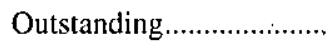 & 60 & 40 \\
\hline 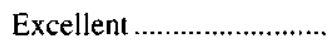 & 50 & 30 \\
\hline Good & 40 & 20 \\
\hline Fair or degrading .............. & 30 & 10 \\
\hline Poor or minimum............... & 10 & 10 \\
\hline Severe degradation........... & $<10$ & $<10$ \\
\hline
\end{tabular}

\section{New England Aquatic- Base-Flow Method}

For free-flowing, unregulated rivers, the ABF Method establishes summer streamflow requirements from the August median flow. August median flow is assumed to represent the month of greatest stress for aquatic organisms because of low flows and high temperatures. The U.S. Fish and Wildlife Service (USFWS) calculates the ABF August median-flow statistic as the median of the annual monthly mean flows for August (U.S. Fish and Wildlife Service, 1981). An August median-flow statistic also can be calculated as the median of the daily mean flows for August (Charles Ritz Associates, 1987; Ries, 1997). Medians calculated from monthly mean streamflows tend to be higher than those calculated from daily mean streamflows because a small number of storms skew the monthly mean value upward, and the effects of land and water use tend to skew the daily mean values downward (Lang, 1999). Consequently, "August median flow" statistics calculated as the median monthly mean flow for August and the median daily mean flow for August are not equivalent.

The USFWS (1981) recommends calculating seasonal streamflow requirements for free-flowing, unregulated streams from discharges normalized for drainage area (table 5). These discharges are determined from gaging stations with drainage areas of $50 \mathrm{mi}^{2}$ or more, which have 25 years of good- or excellent-quality record. For ungaged or regulated streams, the ABF method sets a default streamflow requirement of $0.5\left(\mathrm{ft}^{3} / \mathrm{s}\right) / \mathrm{mi}^{2}$ for the summer period;
Table 5. Seasonal New England Aquatic-Base-Flow default streamflow requirements

[Source: U.S. Fish and Wildlife Service, 1981. $\left(\mathrm{ft}^{3} / \mathrm{s}\right) / \mathrm{mi}^{2}$, cubic foot per second per square mile]

\begin{tabular}{llc}
\hline \multicolumn{1}{c}{$\begin{array}{c}\text { Season } \\
\text { (months) }\end{array}$} & Period & $\begin{array}{c}\text { Instantaneous } \\
\text { streamflow } \\
{\left[\left(\mathrm{ft}^{3} / \mathbf{s}\right) / \mathrm{mi}^{2}\right]}\end{array}$ \\
\hline $\begin{array}{l}\text { Summer (mid-June to } \\
\text { mid-October) }\end{array}$ & low flow & 0.5 \\
$\begin{array}{l}\text { Fall/Winter (mid-October } \\
\text { to March) }\end{array}$ & $\begin{array}{c}\text { spawning and } \\
\text { incubation }\end{array}$ \\
Spring (April to mid-June) & $\begin{array}{c}\text { spawning and } \\
\text { incubation }\end{array}$ & 4.0 \\
\hline
\end{tabular}

this default value was designed to be a resourceconservative flow for habitat protection. The median monthly mean flow for August may vary from the default value from basin to basin because of differences in the percentage of stratified drift, the distribution of riparian wetlands, and precipitation patterns. Basins with large areas of stratified drift tend to have higher low flows relative to basins that are predominantly glacial till or bedrock (Thomas, 1966; Cervione and others, 1982). Areas of large riparian wetlands can decrease low flow substantially as a result of increased evapotranspiration (Wandle and Randall, 1994). Drainage areas to the windward and lee of New England mountains with respect to prevailing westerly winds may have differences in precipitation patterns because of orographic effects (Kulik, 1990). In this study, streamflow requirements determined by the ABF summer default flow are compared to the median of monthly mean flow values for August determined from model-simulated, long-term flows without withdrawals.

\section{Wetted-Perimeter Method}

Wetted perimeter is used as a measure of the availability of aquatic habitat over a range of discharges (Annear and Conder, 1984; Nelsen, 1984). This method assumes that the carrying capacity of a stream is proportional to fish-food producing areas and that wetted perimeter in riffles is an index of this relation (Lohr, 1993). The wetted perimeter of a stream is the width of streambed and stream banks in contact with water for an individual cross section (fig. 7). The method requires knowledge of the relation of wetted 

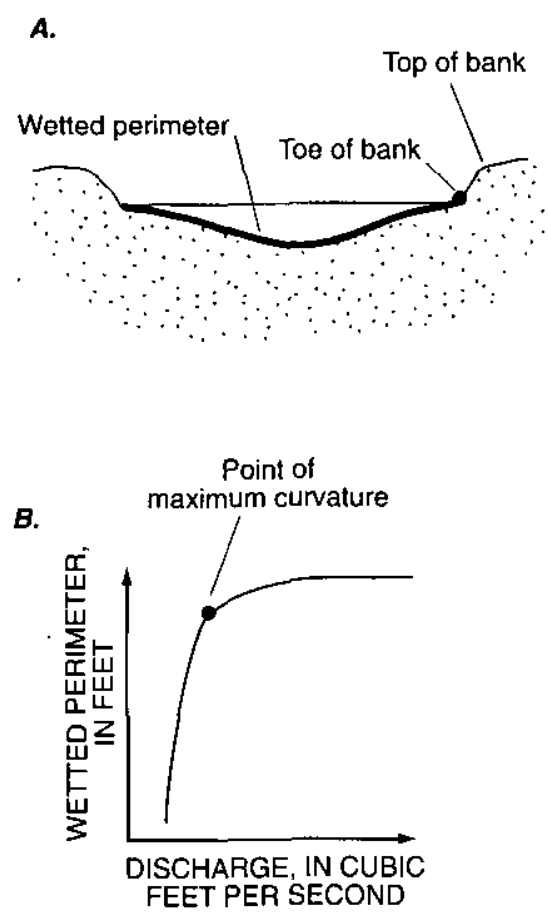

Figure 7. (A) Hypothetical streamchannel cross section and $(B)$ Graph of relation between wetted perimeter and discharge.

perimeter to discharge. For natural channels, the slope of the discharge and wetted-perimeter curve typically has one or more transitions from a steep slope at small discharges to a more gentle, gradual slope at larger discharges. The streamflow required for habitat protection usually is chosen as the point of maximum curvature in the relation between wetted perimeter and discharge. On a channel cross section, this point theoretically corresponds to the break in slope at the bottom of the bank where, as stage increases, the water begins to rise up the stream banks.

Stream cross sections vary considerably, so the effectiveness of the Wetted-Perimeter method is highly dependent upon the cross sections selected in the field. The method is best applied in riffles with wide, shallow, rectangular channels
(Espegren, 1998) where the point of maximum curvature typically corresponds to flows that fill the channel to the bottom of the stream banks. In rectangular channels, water levels that rise above the bottom of the banks cause small increases in wetted perimeter, and water levels that fall below the bottom of the banks cause large decreases in wetted perimeter. Transition points in triangular or trapezoidal channels are determined more by the way discharge increases with depth than by the way wetted perimeter changes with depth (Gippel, 1996).

In practice, there is seldom a single break in slope in the wettedperimeter-to-discharge relation. The relation can show multiple breaks in slope that do not coincide with field-identified elevations for toe-of-bank, or a fully wetted channel bed. Many cross sections have a deep portion of the channel (thalweg) in which streamflow is confined during low flows; for these channels, the relation of wetted perimeter to discharge exhibits multiple breaks in slope corresponding to flows that spill out of the low-flow channel. Breaks in slope in the wetted-perimeter-todischarge relation can also correspond to the points where water rises over geomorphic features of the streambed, such as bars or boulders, or over uneven bank topography. The number and density of points surveyed along a cross section can affect the shape of the discharge and wettedperimeter curve and the number of break points on the curve. These multiple break points can correspond to differences in wetted perimeter between pairs of points that are surveyed at close to the same elevation on opposite banks. Other factors that affect the wetted-perimeter-todischarge relation include the shape of the channel, size of the bed material, altered or constructed banks, and backwater effects from downstream.

For this study, multiple cross sections were surveyed at critical riffle sites for use in the wetted-perimeter analysis. The most detailed cross-section data were collected at the upstream cross section that served as the hydraulic control. Hydraulic controls are sections or reaches of the channel, such as riffles, rock outcrops, or channel constrictions, which eliminate the effects of downstream conditions on the velocity and depth of flow upstream of the section. A step-backwater Water Surface Profile (WSPRO) model (Shearman, 1990) was used to determine stage, mean depth, average velocity, and wetted-perimeter relations for each cross section for a range of discharges. The WSPRO models were calibrated to several discharge measurements at each site. In this study, wetted-perimeter streamflow requirements were determined from the discharge that corresponded to a fully wetted channel bed. Precise determination of the elevation corresponding to a fully wetted channel bed (the point where the water level reaches the bottom of the stream banks) required supplementing information determined from plots of wetted perimeter to discharge with toe-of-bank elevations identified during field surveys.

\section{R2Cross Method}

The $\mathrm{R} 2$ Cross method requires selection of a critical area of the stream, such as a riffle, and assumes that a discharge chosen to maintain habitat in the riffle is sufficient to maintain fish habitat in nearby pools and runs for most life stages of fish and aquatic invertebrates (Nehring, 1979). 
Streamflows required for habitat protection are determined from flows that meet criteria for three hydraulic parameters: mean depth, percent of bankfull wetted perimeter, and average velocity (table 6; Espegren, 1996). R2Cross criteria for the hydraulic parameters are grouped by stream width. The R2Cross method has been reported to produce similar results to those of the Instream Flow Incremental Methodology (IFIM) for some sites (Espegren, 1996).

Stage-to-discharge relations and values for the hydraulic parameters at different discharges were simulated for critical riffle sites by use of WSPRO hydraulic models (Shearman, 1990). Data requirements for the model include surveyed cross sections, streambed slopes, and water levels. Manning's roughness coefficients were estimated for various water depths and determined to be within reasonable limits for each site by comparison to photographs of similar riffle reaches in Barnes (1967) and Hicks and Mason (1991). Several discharge measurements were made at each site at different flows, and WSPRO models were calibrated to match as closely as possible the measured discharges through adjustment of roughness coefficients and water-surface slope.

\section{Range of Variability Approach}

Poff and others (1998) suggest that the native biodiversity and integrity of river ecosystems can be sustained by the maintenance of the natural pattern of flow variability that created that diversity. Recognizing this need, Richter and others (1997) developed the Indicators of Hydrologic Alteration (IHA) method to characterize intra-annual flow variability. The IHA method uses long-term-flow data for calculating ecologically relevant hydrologic statistics that are divided into five general groups (table 7).

Table 6. R2Cross criteria for hydraulic parameters for protection of aquatic habitat

[Source: Espegren, 1996. ft, foot: ft/s, foot per second; $\geq$, greater than or equal tol

\begin{tabular}{cccc}
\hline $\begin{array}{c}\text { Stream top } \\
\text { width } \\
\text { (ft) }\end{array}$ & $\begin{array}{c}\text { Mean } \\
\text { depth } \\
\text { (ft) }\end{array}$ & $\begin{array}{c}\text { Bankfull wetted } \\
\text { perimeter } \\
\text { (percent) }\end{array}$ & $\begin{array}{c}\text { Mean } \\
\text { velocity } \\
\text { (ft/s) }\end{array}$ \\
\hline $1-20$ & 0.2 & 50 & 1.0 \\
$21-40$ & $0.2-0.4$ & 50 & 1.0 \\
$41-60$ & $0.4-0.6$ & $50-60$ & 1.0 \\
$61-100$ & $0.6-1.0$ & $\geq 70$ & 1.0 \\
\hline
\end{tabular}

Table 7. Range of variability approach: flow statistics for characterization of intra-annual hydrologic variation

[Source: Richter and others, 1996]
General Group

The magnitude of monthly discharge

The magnitude and duration of annual extreme discharge

The timing of annual extreme discharge

The frequency and duration of high and low flow hydrographic change
The rate and frequency of

\section{Streamflow parameters}

Monthly mean discharge for each month.

Annual minimum and maximum for 1-, 3-, 7-, 30-, and 90-day periods: number of zero flow days; 7-day minimum flow divided by mean flow for year.

Julian date of the annual minimum and maximum daily flow.

Number of low flow and high flow pulses per year; mean duration of low flow and high flow pulses.

Means of all positive and negative flow differences between consecutive daily means; number of flow rises and falls.
Richter and others (1997) also developed an adaptive management approach, known as the Range of Variability Approach (RVA), that identifies a target flow regime similar to a stream's natural flow as measured by the range of natural variation in 33 different flow parameters. This approach sets appropriate measures of variability for the monthly IHA flow values as either I standard deviation from the mean flow, or the 25 th and 75 th percentiles of the monthly mean flow. Nonparametric measures of dispersion (the 25th and 75 th percentiles of the mean flow) were used in this study because hydrologic data are often skewed, and to compare these flows with the median $\left(50^{\text {th }}\right.$ percentile) of monthly mean flow that were calculated for the ABF method. Richter and others (1997) point out that the targeted range will not be attained every year because of natural flow variability, but suggest that it should be attained at the same frequency as the natural or predevelopment flow regime. When long-term streamflow data or data from a river's natural flow regime are unavailable, Richter and others (1997) suggest synthesis of records of daily streamflow by use of hydrologic simulation models. The HSPF runoff model developed by Zarriello and Ries (2000) provides the best available estimate of natural flow for the Ipswich River. 


\section{Flow Statistics}

Low-flow statistics were computed from the model-simulated data to determine the low-flow conditions that would have occurred in the absence of withdrawals for public-water supply. Further, these statistics for most streams can be obtained in Massachusetts by use of a World Wide Web application, called STREAMSTATS, developed by Ries and Friesz (2000) [http://ma.water.usgs.gov/streamstats]. The statistics provided by STREAMSTATS are estimated values for unregulated streams at ungaged sites or actual flow statistics at gaged sites. These statistics include flow durations and annual 7-day low flows that have a 2- and 10-year recurrence interval.

Flow duration curves are cumulative-frequency curves that show the percentage of time a specified flow is equaled or exceeded. The curves reflect the combined effects of climate, topography, and hydrogeologic conditions on the distribution of flow magnitudes through time (Searcy, 1959). The percentage of time particular flows are equaled or exceeded, commonly referred to as flow indices, are used in some States to determine streamflow requirements. For instance, in Minnesota, flow is classified as normal when it is between the 25- and 75-percent exceedence probability $\left(\mathrm{Q}_{25}\right.$ and $\left.\mathrm{Q}_{75}\right)$, low when it is between $\mathrm{Q}_{75}$ and the 90-percent exceedence probability (Q90), and critical when it falls below $\mathrm{Q}_{90}$. Minnesota has regulatory authority to implement water-use restrictions when flows are at $\mathrm{Q}_{90}$ or greater exceedence probabilities. New Hampshire's Draft Instream Flow Rules (Currier, 2000) proposed flow-exceedence thresholds for the protection of stream habitat at the 60-percent exceedence probability $\left(\mathrm{Q}_{60}\right)$, the 80 -percent exceedence probability $\left(\mathrm{Q}_{80}\right)$, and $\mathrm{Q}_{90}$.

The annual 7-day mean low flows that occur on average once every 2 and 10 years $\left(7 Q_{2}\right.$ and $7 Q_{10}$, respectively) are used by some States for the determination of minimum streamflow for regulatory purposes. These statistics are calculated by fitting a log-Pearson Type III distribution to the annual 7-day low flow to compute recurrence probabilities. In general, a 7Q 10 flow provides very limited habitat for fish in riffles (Orth and Leonard, 1990); in Massachusetts a 7Q10 flow is about equivalent to or slightly less than the 99 percent flow duration, and a $7 Q_{2}$ flow generally is between the 98- and 95-percent flow duration (Ries and Friesz, 2000).

\section{HABITAT ASSESSMENT}

A reconnaissance of the mainstem of the Ipswich River was done in July and August of 1998 and in tributaries of the Ipswich River in May of 1999 to identify and delineate stream macrohabitat, and to determine accessibility before the selection of sampling sites. Habitat and fish-community data were collected from a total of 37 reaches in the Ipswich River Basin between August 1998 and July 1999 (table 8); these reaches included 27 sites on the mainstem Ipswich River and 10 sites on the tributaries. Sampled tributaries included Howlett Brook, Fish Brook, Boston Brook, Norris Brook, Martins Brook, and the Skug River (the headwater of Martins Brook). Stream widths for the study sites ranged from 22 to $78 \mathrm{ft}$ on the mainstem Ipswich and from 17 to $40 \mathrm{ft}$ in the tributaries. Stream depths for the study sites ranged from 0.8 to $6.0 \mathrm{ft}$ on the mainstem Ipswich and from 0.15 to $1.6 \mathrm{ft}$ in the tributaries.

The low topographic relief of the Ipswich River Basin leads to a predominance of glide-and-pool habitats over riffle-and-run habitats (fig. 8). Slow-water velocities, smooth unbroken water surfaces, and sandsize bed material characterize stream habitat along much of the mainstem Ipswich River. Higher velocity, turbulent-water riffles and runs are less common on the mainstem than in the tributaries. The largest riffle-andrun reaches on the mainstem are located downstream of the South Middleton and Willowdale Dams, and near Route 1 in Topsfield and Mill Road in Ipswich. Most other riffles are isolated, short in length, and are located at bridge structures, at remains of old bridge abutments or old mill dams, or areas of fill. Moderately deep ponded habitat is found in the impoundments behind the three dams on the river, in flow-through ponds such as Ipswich Park Pond in North Reading, in the canals for the Salem-Beverly and Peabody Water Supplies, in large scour holes downstream of bridges, and behind beaver dams.

In the absence of coarse streambed or bank substrate, the type of cover in a reach is related to the type of riparian vegetation. In reaches with predominantly forested riparian vegetation, the dominant cover features are woody debris, exposed roots, and undercut banks supported by tree roots (fig. 9). 
Table 8. Site name, site identifier, date sampled, and location of sample sites, Ipswich River Basin, Massachusetts

[USGS Habitat Site ID: First letter of stream name and downstream order along identified stream. River Distance: distance above mouth for stream indicated. Latitude and Longitude: In degrees, minutes, seconds. ID, identifier; MDFW, Massachusetts Division of Fish and Wildlife; USGS, U.S. Geological Survey; m, meter; --, not measured]

\begin{tabular}{|c|c|c|c|c|c|c|c|c|}
\hline $\begin{array}{l}\text { USGS } \\
\text { habitat } \\
\text { site ID }\end{array}$ & $\begin{array}{l}\text { MDFW } \\
\text { ID }\end{array}$ & Stream name & Location & Town & $\begin{array}{l}\text { Date } \\
\text { sampled }\end{array}$ & $\begin{array}{l}\text { River } \\
\text { distance } \\
\text { (m) }\end{array}$ & $\begin{array}{l}\text { Latitude } \\
0,11\end{array}$ & $\begin{array}{l}\text { Longitude } \\
0, " 1\end{array}$ \\
\hline \multicolumn{9}{|c|}{ Ipswich River } \\
\hline $\mathrm{I} 2$ & 11 & Ipswich River & Downstream of Woburn Street & Wilmington & $8-12-98$ & 55,980 & 423310 & 710827 \\
\hline I8 & 1 & Ipswich River & Downstream of Mill Street & North Reading/Reading & $8-25-98$ & 53,190 & 423340 & 710707 \\
\hline I9 & 3 & Ipswich River & Upstream of Route 28 & North Reading/Reading & $8-26-98$ & 51,920 & 423351 & 710629 \\
\hline I9a & 2 & Ipswich River & Downstream of Route 28 & North Reading/Reading & -- & -- & -- & -- \\
\hline I10 & 4 & Ipswich River & Upstream of power line & North Reading & $8-26-98$ & 51,370 & 423401 & 710613 \\
\hline I11 & 7 & Ipswich River & $\begin{array}{l}\text { Downstream of Martins } \\
\text { Brook }\end{array}$ & North Reading & $8-26-98$ & 50,690 & 423416 & 710557 \\
\hline $\mathrm{I} 12$ & 6 & Ipswich River & $\begin{array}{l}\text { Downstream of Chestnut } \\
\text { Street (adjacent to Parrish } \\
\text { Park) }\end{array}$ & North Reading & $8-27-98$ & 50,340 & 423418 & 710543 \\
\hline I14 & 23 & Ipswich River & $\begin{array}{l}\text { Downstream of Central Street } \\
\text { (Ipswich Park Pond) }\end{array}$ & North Reading & $9-23-98$ & 49,600 & 423421 & 710516 \\
\hline I15 & 26 & Ipswich River & $\begin{array}{l}\text { Downstream of Central Street } \\
\text { (Ipswich Park Pond) }\end{array}$ & North Reading & $9-23-98$ & 49,600 & 423421 & 710516 \\
\hline I17 & 14 & Ipswich River & $\begin{array}{l}\text { Adjacent to Washington Street } \\
\text { (Route 62), behind } \\
\text { firehouse }\end{array}$ & North Reading & $9-01-98$ & 48,650 & 423421 & 710439 \\
\hline 118 & 8 & Ipswich River & $\begin{array}{l}\text { Between South Middleton } \\
\text { Dam and Russell Street }\end{array}$ & Middleton/Peabody & $8-28-98$ & 42,680 & 423411 & 710148 \\
\hline I19 & 42 & Ipswich River & $\begin{array}{l}\text { Between South Middleton } \\
\text { Dam and Russell Street }\end{array}$ & Middleton/Peabody & $7-20-99$ & 42,680 & 423411 & 710148 \\
\hline $\mathrm{I} 20$ & 5 & Ipswich River & $\begin{array}{l}\text { Downstream of Russell Street, } \\
\text { upstream of South } \\
\text { Middleton gage } \\
(01101500)\end{array}$ & Middleton/Peabody & $8-28-98$ & 42,500 & 423411 & 710141 \\
\hline $\mathrm{I} 23$ & 9 & Ipswich River & $\begin{array}{l}\text { Downstream of Log Bridge } \\
\text { Road, near Biuleys Corner }\end{array}$ & Middleton/Danvers & $8-28-98$ & 36,950 & 423446 & 705929 \\
\hline $\mathrm{I} 24$ & 10 & Ipswich River & $\begin{array}{l}\text { Upstream of Maple Street } \\
\text { (Route 62), near Middleton } \\
\text { Colony }\end{array}$ & Middleton & $9-24-98$ & 35,250 & 423524 & 705949 \\
\hline $\mathrm{I} 25$ & 12 & Ipswich River & $\begin{array}{l}\text { Upstream of Maple Street } \\
\quad \text { (Route } 62 \text { ) }\end{array}$ & Middleton & $9-28-98$ & 34,000 & 423543 & 705948 \\
\hline 126 & 15 & Ipswich River & Upstream of Peabody Bridge & Middleton & $9-09-98$ & 31,200 & 423650 & 705955 \\
\hline 127 & 13 & Ipswich River & $\begin{array}{l}\text { Downstream of Thunder } \\
\text { Bridge }\end{array}$ & Middleton & $9-11-98$ & 29,550 & 423714 & 705911 \\
\hline I 29 & 16 & Ipswich River & $\begin{array}{l}\text { Upstream of Rowley Bridge } \\
\text { Road }\end{array}$ & Topsfield/Middleton & $9-14-98$ & 27,300 & 423737 & 705803 \\
\hline I31 & 17 & Ipswich River & Downstream of Salem Street & Topsfield & $9-18-98$ & 25,250 & 423731 & 705655 \\
\hline
\end{tabular}


Table 8. Site name, site identifier, date sampled, and location of sample sites-Continued

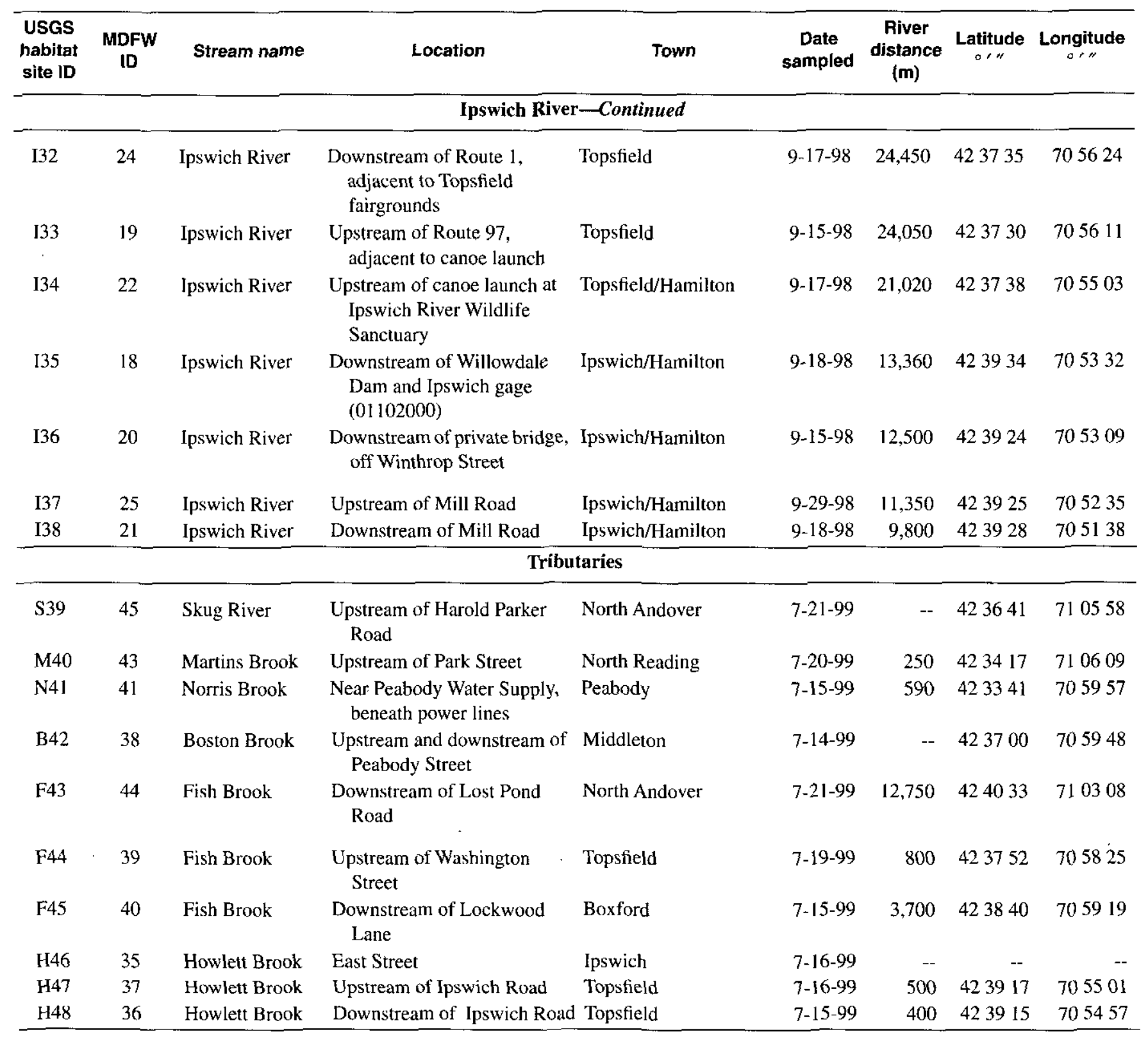




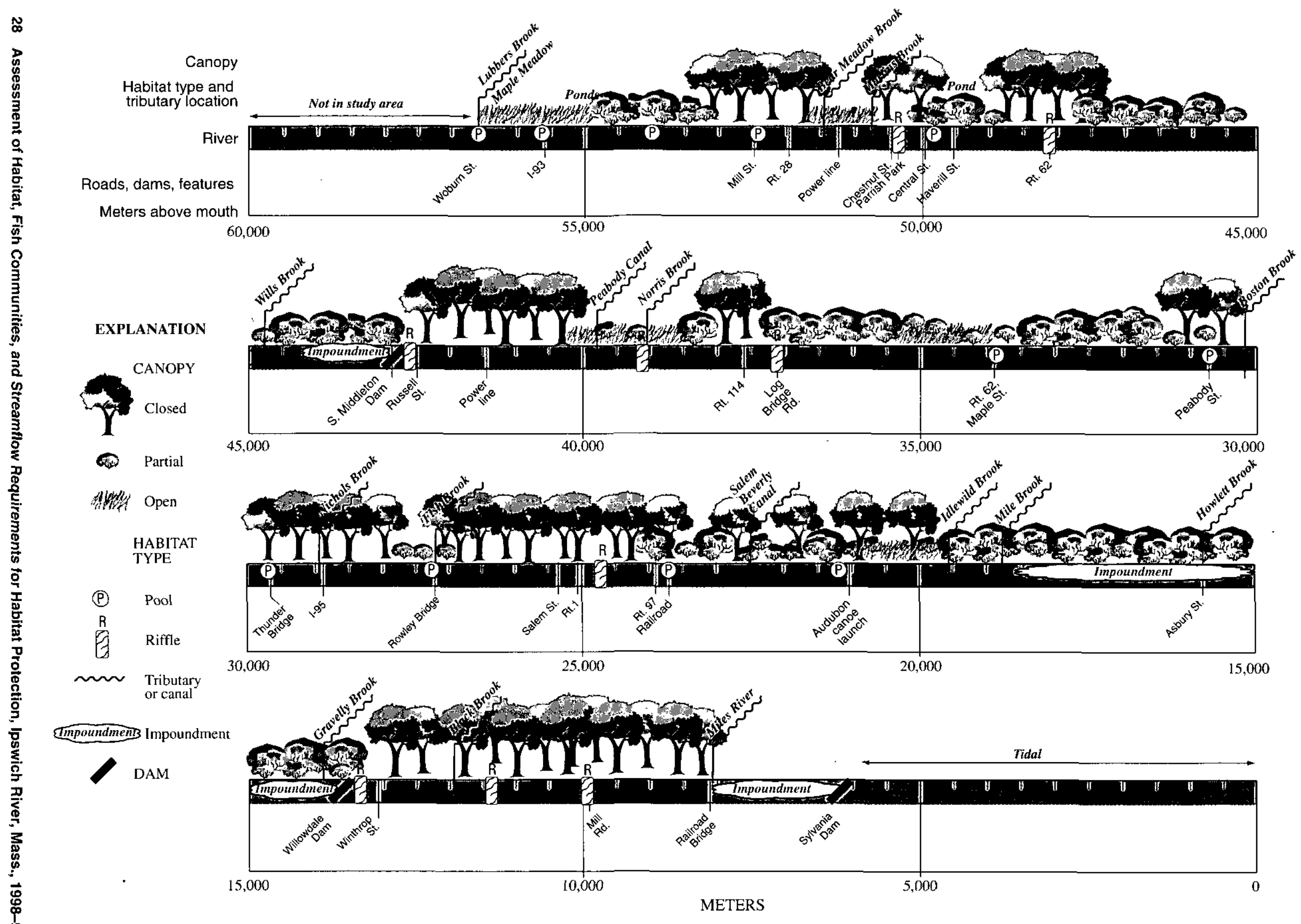

Figure 8. Habitat types of the Ipswich River, Massachusetts, mainstem. 
A.

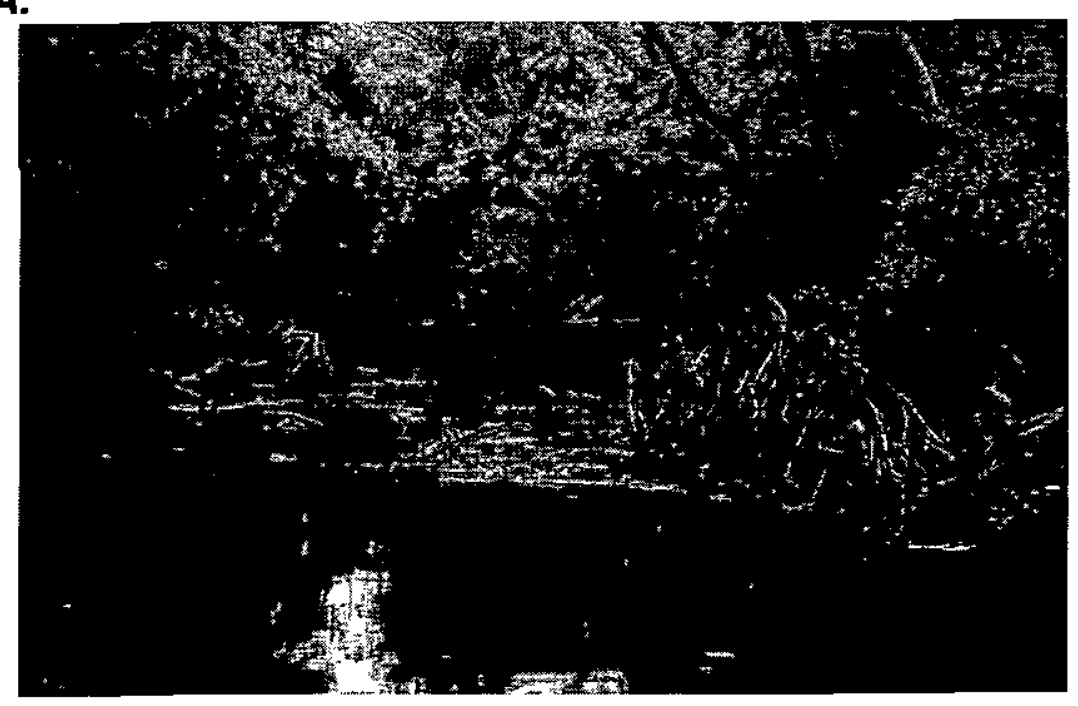

B.

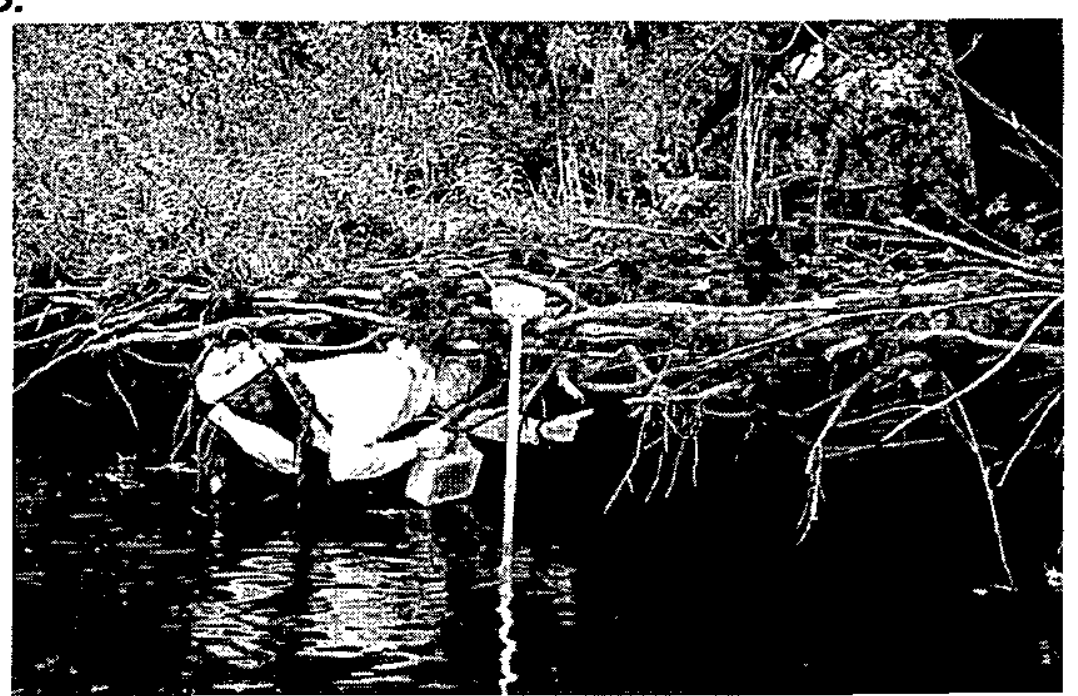

c.

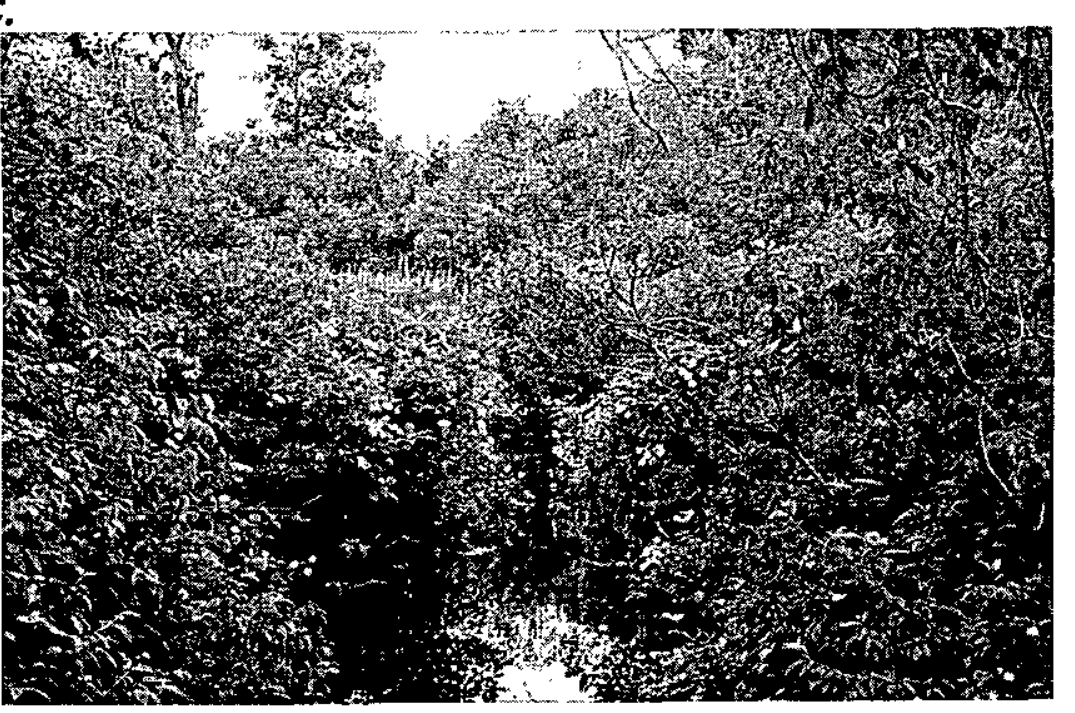

D.

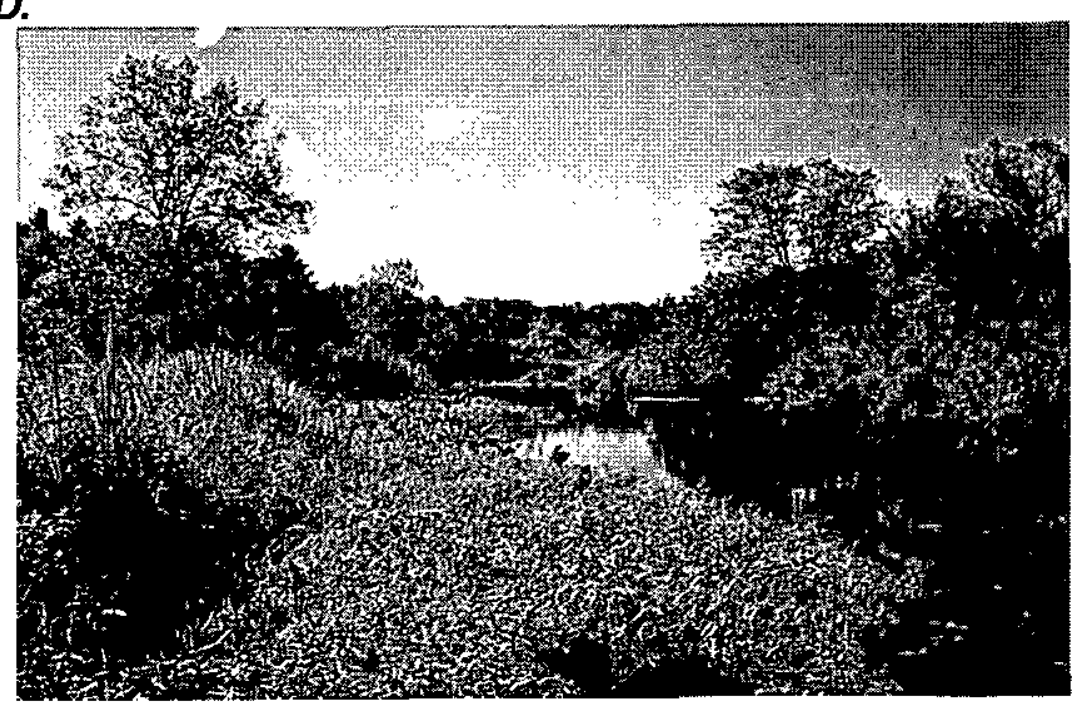

Figure 9. Common habitat features along the Ipswich River, Massachusetts: $(A)$ woody debris, downstream view; $(B)$ undercut banks and exposed roots, view of right bank; $(C)$ overhanging shrubs, downstream view, and $(D)$ submerged, emergent, and floating aquatic vegetation, upstream view. 
These features are found mostly along the stream margins. In reaches that are characterized by shrub riparian vegetation, the dominant cover features are overhanging vegetation and small woody debris. Stream width and riparian vegetation type determine whether reaches have an open, shaded, or partially shaded canopy. Wide reaches or wetland reaches dominated by grass, sedge, or emergent riparian vegetation are mostly open to sunlight, which can penetrate to the streambed. The primary cover feature in these reaches is submerged, emergent, and floating aquatic vegetation.

\section{Habitat Types in the Ipswich River}

The predominant stream habitats can be categorized as glide and pool with an open canopy; glide and pool with a partially open canopy; glide and pool with a partially closed or closed canopy; riffle and run; and ponded habitats. Each of these habitat types has distinct characteristics.

\section{Glide-and-Pool Habitats with an Open Canopy}

Glide-and-pool habitats with an open canopy are associated with low-gradient reaches with bordering wetlands. The downstream ends of these reaches commonly have a constriction of the stream valley or channel, a riffle, or other hydraulic control such as a bridge. These hydraulic controls, together with the low stream gradient, cause frequent overbank flooding in the wetland reaches during spring and early summer. Other common reach characteristics are high sinuosity channels, slow water velocities, flat unbroken water surfaces, sand streambeds, and organic soil or peat streambanks. In some areas that commonly have beds of submerged vegetation, the streambed material is fine particulate organic matter (FPOM) overlying sand. Water depths generally are less than $5 \mathrm{ft}$, but range from $1 \mathrm{ft}$ to $10 \mathrm{ft}$, and generally are deepest in meanders and in scour holes downstream of bridges. Riparian vegetation is typically grasses, emergent aquatic or herbaceous vegetation, and shrubs (fig. 10). Common grassy vegetation includes reed canary grass (Phalaris arundinacae), bluejoint grass (Calamagostis canadensis), common reed (Phragmites australis), and

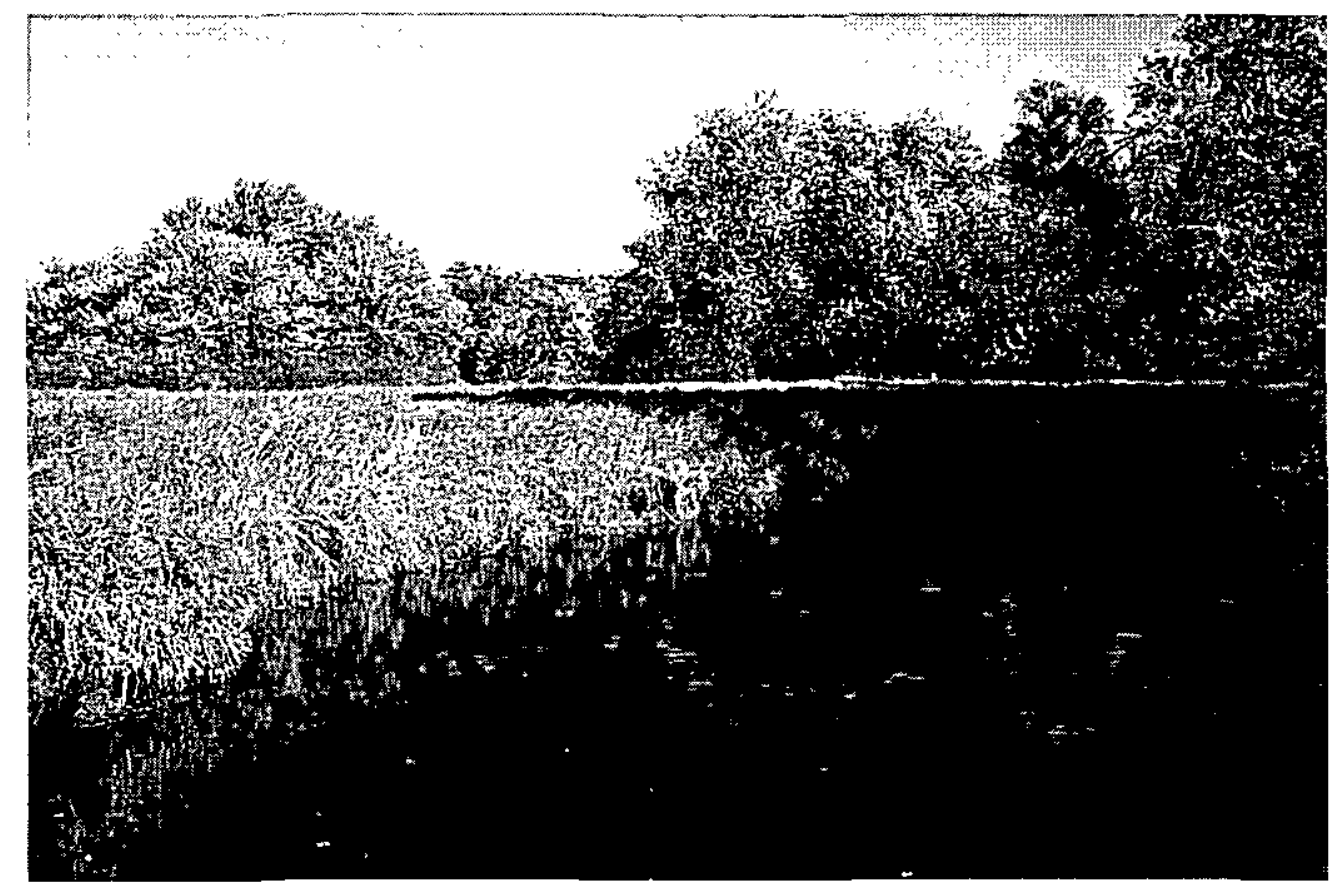

Figure 10. Glide-and-pool habitats with an open canopy, Audubon Wildlife Sanctuary, Ipswich River, Massachusetts, downstream view. 
tussock sedge (Carix stricta) (W. Kittridge, Harvard Herbariam, oral commun., 2000). Purple loosestrife (Lythrum salicaria), an invasive non-native species, is the dominant herbaceous plant in many reaches. Common shrubs include buttonbush (Cephalanthus occidentalis) and silky dogwood (Cornus amomum).

The open canopy over these reaches allows sunlight to reach the stream, which permits the growth of submerged vegetation such as water celery (Vallisneria americana), bur-reed (Sparganium spp.), and pondweed (Potamogeton spp.), and floating and emergent vegetation such as water smartweed (Polygonum amphibium) and pickerelweed (Pontederia cordata). In backwater and impounded reaches, floating aquatic vegetation such as duckweed (Lemna spp.) and water lilies (Nymphaea spp.), and emergent aquatic vegetation such as arrow-arum (Peltandra virginica) are common. Fish cover in these reaches is provided primarily by submerged, floating, and emergent aquatic vegetation, undercut banks, overhanging grass, and deep pools located on meander bends and in scour holes downstream of bridges. In some reaches additional fish cover is in oxbow channels and other streamside pools.
Examples of glide-and-pool habitats with an open canopy can be found upstream and downstream of I-93 in Wilmington, upstream of Chestnut Street in North Reading, upstream and downstream of Route 114 in Middleton/Danvers, and in the Ipswich River Audubon Sanctuary in Topsfield, Wenham, and Hamilton. Additional photographs of study sites that have glide-and-pool habitats with an open canopy are shown in Appendix A.

\section{Glide-and-Pool Habitats with a Partially Open Canopy}

Glide-and-pool habitats with a partially open canopy are similar to glide-and-pool habitats with an open canopy, except for the predominance of shrubs in the riparian vegetation (fig. 11). Glide-and-pool habitats with a partially open canopy occur both in long homogeneous reaches and also in patches within reaches having an open canopy or a forested floodplain. Like the glide-and-pool reaches with an open canopy, these reaches characteristically have low gradients, highly sinuous channels, low water velocities, flat

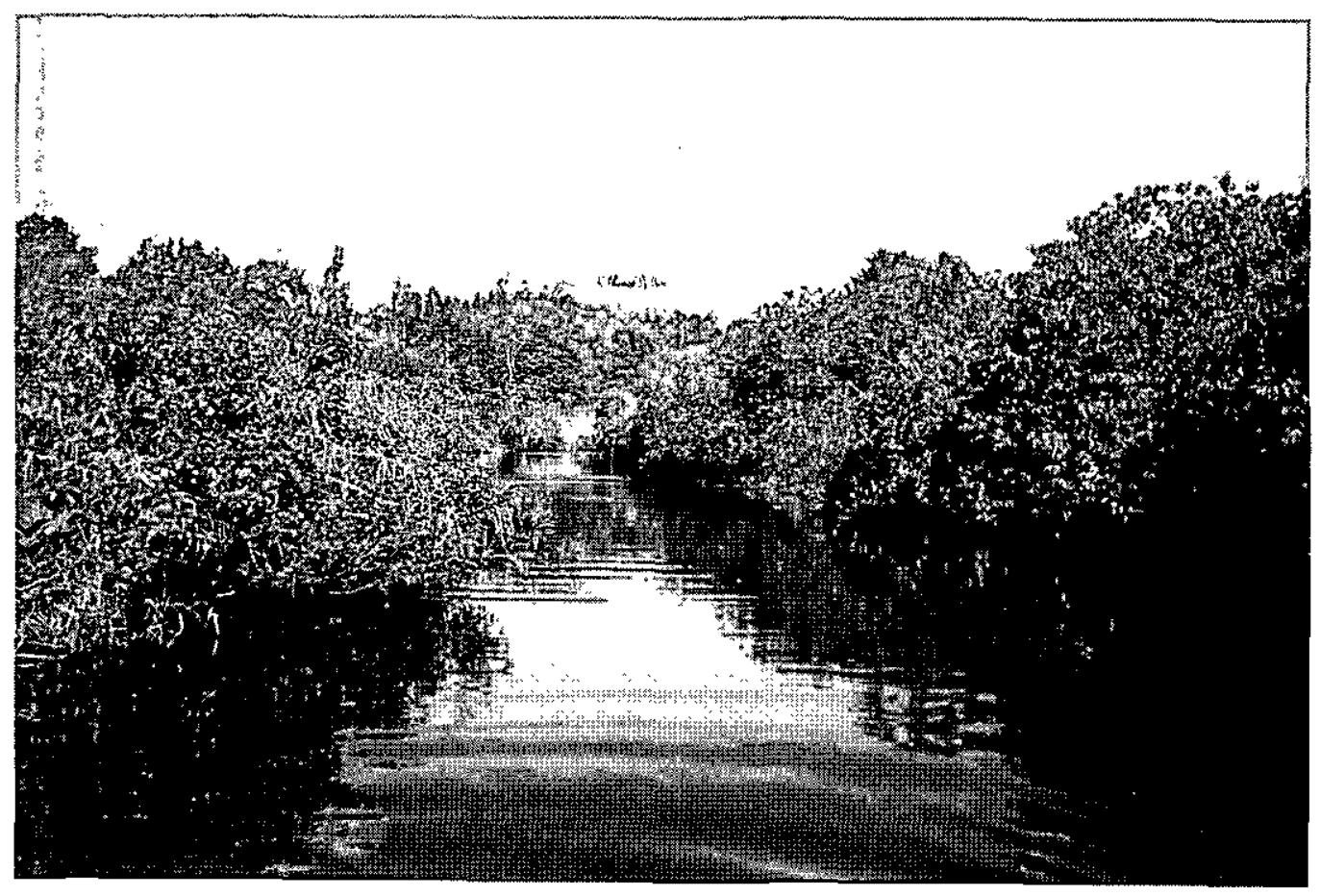

Figure 11. Glide-and-pool habitats with a partially open canopy, upstream of Route 114, Middleton/Danvers, Ipswich River, Massachusetts, downstream view. 
unbroken water surfaces, sand streambeds, and organic soil or peat streambanks. These reaches commonly have less submerged aquatic vegetation than glide-andpool reaches with an open canopy; the amount of submerged aquatic vegetation depends on the amount of sunlight that reaches the stream. Common shrub vegetation includes buttonbush (Cephalanthus occidentalis) and silky dogwood (Cornus amomum). Further back from the stream channel or in areas where the floodplains are higher in elevation, shrubs such as alder (Alnus spp.) and European buckthorn (Rhamnus frangula) are common, along with flood-tolerant trees such as red maple (Acer rubrum), silver maple (Acer saccharinum), ash (Fraxinus spp.), and willow (Salix spp.). Fish cover in these reaches is provided primarily by undercut banks, overhanging shrubs, and deep pools on meander bends and in scour holes downstream of bridges.

Examples of glide-and-pool habitats with a partially open canopy can be found upstream of Woburn Street, Wilmington; upstream of Mill Street, North Reading/Reading; downstream of Washington Street in North Reading; between Log Bridge Road and Maple Street in Middleton/Danvers, and in the Audubon Ipswich River Wildlife Sanctuary in
Topsfield, Wenham, and Hamilton. Additional photographs of sites with glide-and-pool habitats with a partially open canopy are provided in Appendix A.

\section{Glide-and-Pool Habitats with a Partially Closed or Closed Canopy}

Glide-and-pool habitats with a partially closed or closed canopy are the dominant habitat types along the Ipswich River and are common to reaches with bordering forested wetlands, floodplains, and upland (fig. 12). Characteristics of the glide-and-pool habitats with a partially closed or closed canopy are low gradients, slow water velocities, flat unbroken water surfaces, sand streambeds and sand, mineral- or organicsoil streambanks, and bordering shrubs and trees whose extent of canopy cover-partially closed or closed-depends upon stream width and orientation. In some narrow areas typically associated with woody debris, the channel may produce velocities that create run habitat. Because little direct sunlight reaches the stream surface, these reaches commonly have little if any submerged aquatic vegetation. Common trees generally are tolerant of flooding and saturated soil conditions, and include red maple (Acer rubrum) and

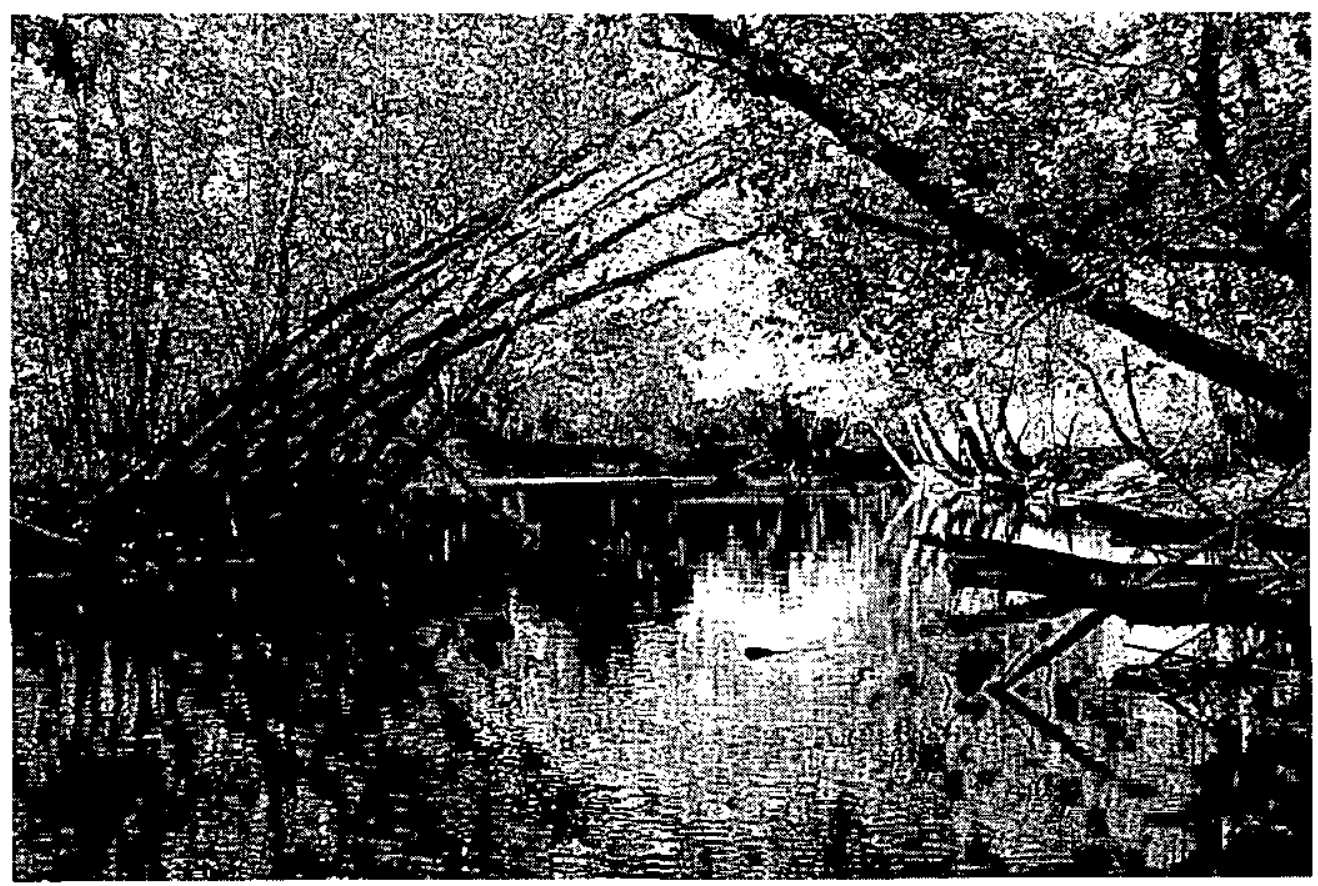

FIgure 12. Glide-and-pool habitats with a partially closed or closed canopy, Massachusetts Audubon Society, Ipswich River Wildlife Sanctuary, Ipswich River, Topsfield, Massachusetts, upstream view. 
silver maple (Acer saccharinum), interspersed with green ash (Fraxinus pennsylvanica), and willow (Salix spp). Fern understories are common. In areas that are less wet or where upland borders the stream channel, species such as oak (Quercus spp.), swamp birch (Betula alleghaniensis), and white pine (Pinus strobes) also are common. Submerged woody debris and downed trees provide good macroinvertebrate habitat. Fish cover in these reaches is provided primarily by woody debris, downed trees, exposed roots, undercut banks supported by tree roots, and deep pools located on meander bends and in scour holes downstream of bridges.

Examples of glide-and-pool habitats with a partially closed or closed canopy can be found downstream of Route 28 in North Reading/Reading, upstream and downstream of Central Street in North Reading, downstream of Russell Street in Middleton/ Peabody; and from Peabody Street in Middleton/ Topsfield to Route 97 in Topsfield. Additional photographs of sites that have glide-and-pool habitats with a partially closed or closed canopy are given in Appendix A.

\section{Riffle-and-Run Habitats}

Riffles and runs are both fast-water habitats. Riffle habitats characteristically have fast flow velocities, shallow water depths, coarse-grained substrates (gravel, cobble, boulder), and turbulent surfaces with small standing waves, eddies, or white water. Run habitats characteristically have moderate flow velocities, shallow to moderate depths, coarse-grained substrates, and unbroken surfaces with little or no turbulence or waves. Rocks and coarse stream substrate provide good macroinvertebrate habitat. Numerous scuds (Gammarus spp.), a freshwater crustacean, were observed in aquatic moss (Fontinalis spp.) that covers boulders and cobbles. Eddies and pockets of slower water behind cobbles and woody debris provide fish cover in these reaches.

Runs tend to be located downstream of riffles, but also can be isolated, such as in areas where the channel is constricted by large woody debris. In many cases, variations in flow can cause riffles to become runs and runs to become riffles. During this study, reaches that were riffles at moderate flows were observed to become runs at higher flows, and reaches that were runs at moderate flows were observed to become riffles at lower flows.

Fifteen riffe habitats were observed along the mainstem of the Ipswich River (table 9). The longest riffles and runs on the mainstem Ipswich River are below the South Middleton Dam in Middleton, downstream of Route 1 in Topsfield, below the Willowdale Dam in Ipswich, and downstream of Mill Road in Ipswich. The longest riffles and runs on the tributaries

Table 9. Location and length of riffle reaches on the mainstem Ipswich River, Massachusetts

[Length: length of the riffle in terms of channel widths; short, less than or equal to about 2-channel widths; long, longer than about 2-channel widths]

\begin{tabular}{|c|c|c|c|}
\hline Location & Town & Description & Length \\
\hline 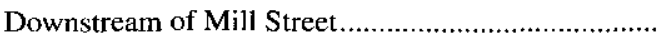 & North Reading/Reading & Old mill site & short \\
\hline 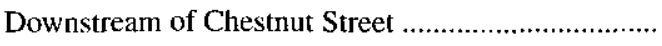 & North Reading & Fill & long \\
\hline 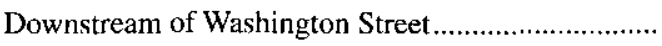 & North Reading & Beneath bridge & short \\
\hline 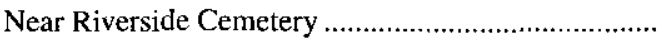 & North Reading/Lynnfield & Constriction at old bridge abutment & short \\
\hline Downstream of the South Middleton Dam ..................... & Middleton/Peabody & Below dam & long \\
\hline Near Riverside Drive & Middleton/Peabody & Constriction at old abutment & short \\
\hline Log Bridge Road & Middleton/Danvers & Constriction at old abutment & short \\
\hline Downstream of Maple Street ...................................... & Middleton & Beneath bridge & short \\
\hline 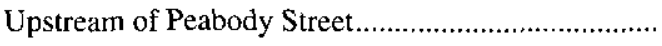 & Middleton & Fill & short \\
\hline 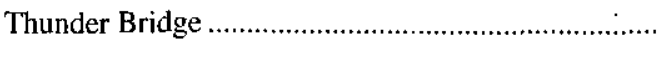 & Middleton & Constructed rock control & short \\
\hline $\begin{array}{l}\text { Downstream of Route } 1 \text { near the Topsfield } \\
\text { fairgrounds }\end{array}$ & Topsfield & Natural & long \\
\hline 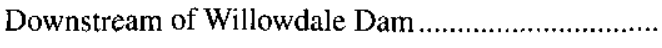 & Ipswich/Hamilton & Below dam & long \\
\hline Winthrop Street & Ipswich/Hamilton & Beneath bridge & short \\
\hline 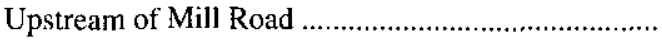 & Ipswich/Hamilton & Constructed rock control & short \\
\hline 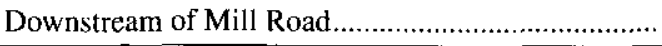 & Ipswich/Hamilton & Old mill site & long \\
\hline
\end{tabular}


were found on Fish Brook near Lockwood Lane, and downstream of Town Road in Boxford. Although many of these riffles and runs appear to be natural (fig. 13A), many are near bridges or old mill sites and may have been altered in the past (fig. 13B). Additional photographs of sites that have riffle-and-run habitat are shown in Appendix A.

\section{Ponded Habitat}

Ponded habitats occur in ponds, water-supply canals (fig. 14), and in impoundments behind dams (fig. 15). These reaches characteristically have low gradients, low water velocities, flat unbroken water surfaces, wide channels, and moderate to deep depths.

A.

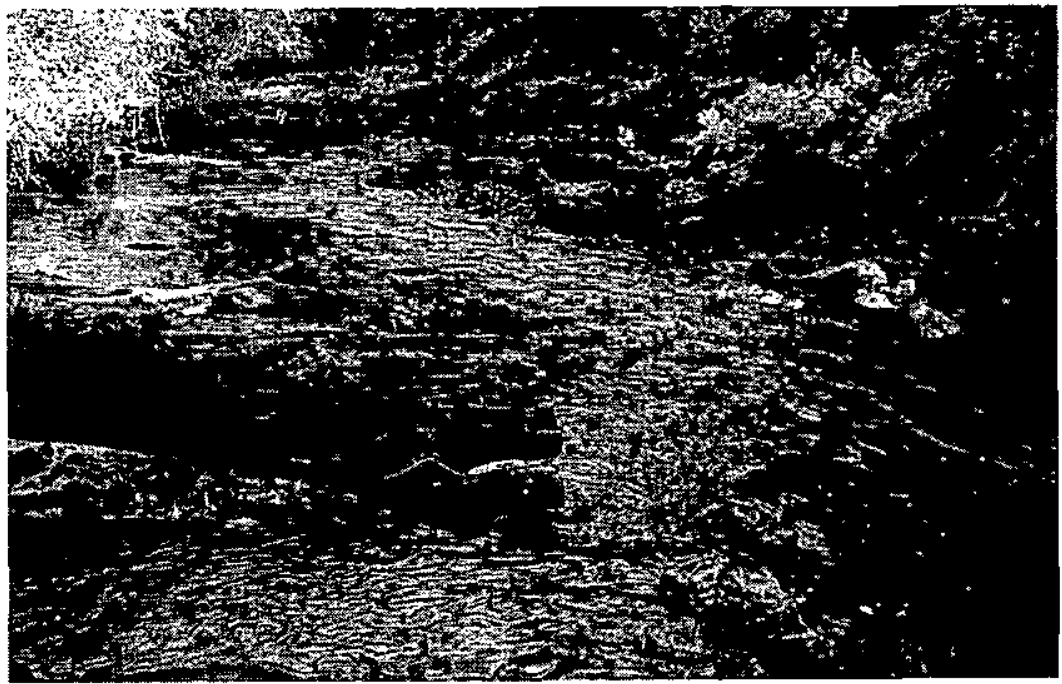

B.

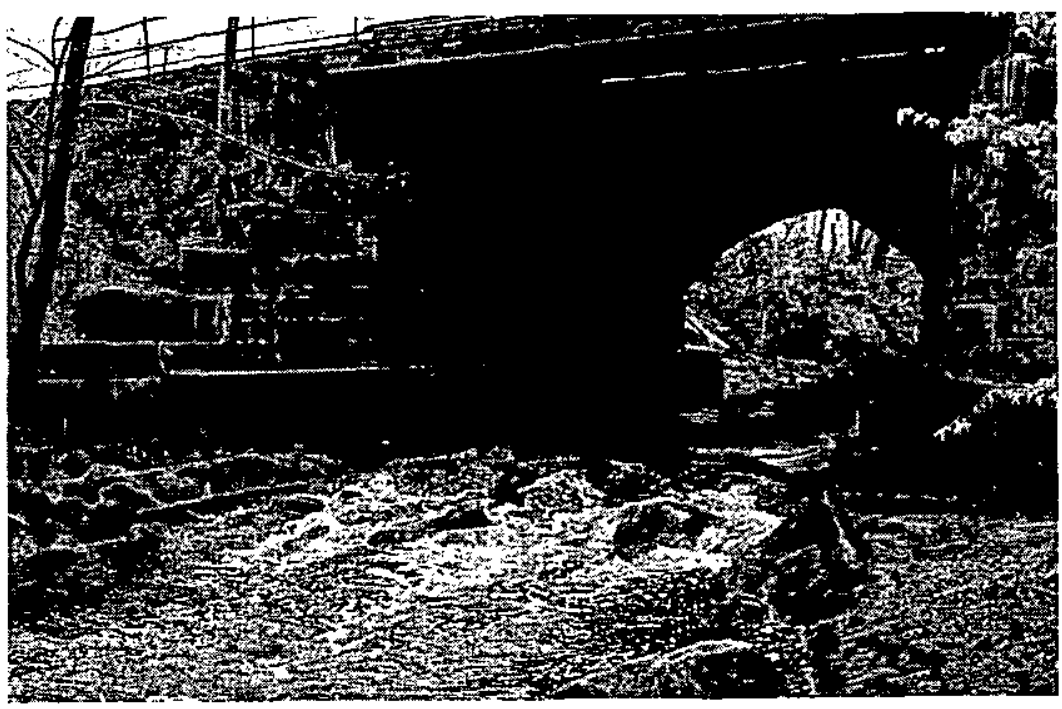

Figure 13. Riffle-and-run habitat: $(A)$ Naturally occurring riffle downstream of Route 1, Topsfield, downstream view; and (B) Altered riffle, Washington Street, North Reading, upstream view, Ipswich River, Massachusetts. 


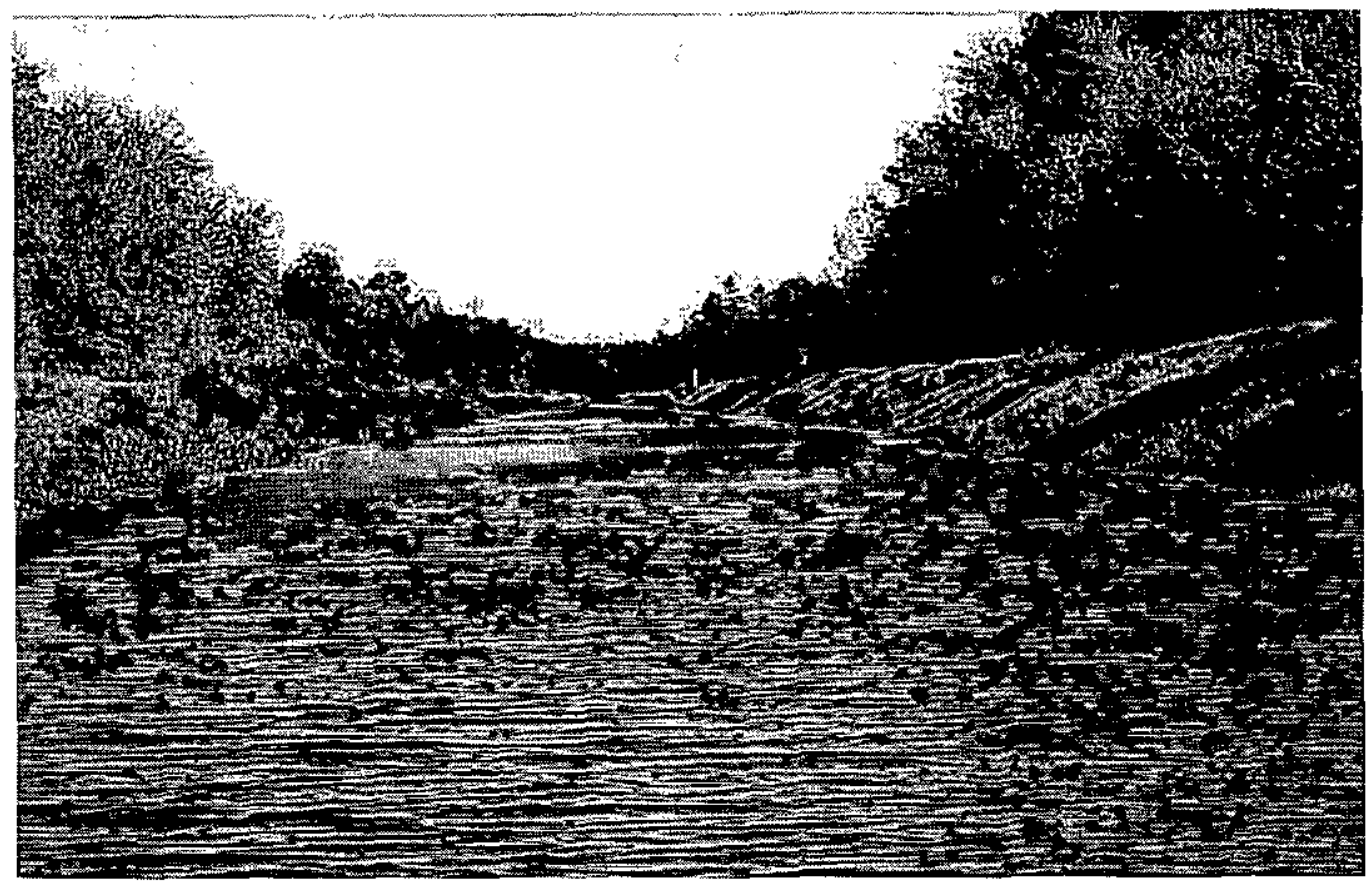

Figure 14. Ponded habitat, Salem-Beverly water-supply canal, Topsfield, Ipswich River, Massachusetts, southeast view.

The open canopy over ponds allows sunlight to reach the stream, which permits the growth of submerged vegetation such as pondweed (Potamogeton spp.), and floating and emergent vegetation such as water smartweed (Polygonum amphibium), pickerelweed (Pontederia cordata), duckweed (Lemna spp.) and water lilies (Nymphaea spp.). Emergent aquatic vegetation such as arrow-arum (Peltandra virginica) is common. Fish cover in these reaches is provided primarily by water depth in combination with submerged, floating, and emergent aquatic vegetation, woody debris, and downed trees.

Ponded habitat is found on the mainstem Ipswich River in the man-made ponds downstream of I-93, in Ipswich Park Pond in North Reading, in ponds behind beaver dams in North Reading, in the water-supply canals for the Salem-Beverly and Peabody Water Supplies, and in the impoundments behind the South Middleton Dam in Middleton, the Willowdale Dam in Ipswich, and the Sylvania Dam in Ipswich (fig. 1).

\section{Habitat Scoring by the Rapid Bioassessment Protocol}

Physical habitat characteristics visually examined over the study reach and measured at transect sites (Appendixes A and B) were used to score the habitat by use of USEPA Rapid Bioassessment Protocols (table 10). Scores on the mainstem Ipswich in 1998 ranged from a high of 178 at site I12, a riffle downstream of Chestnut Street in North Reading, to a low of 141 at site I33, a site upstream of Route 97 in Topsfield. The average score for mainstem sites was 159. Scores on Ipswich tributaries in 1999 ranged from a high of 173 at site M40 on Martins Brook upstream of Park Street, to a low of 100 at site B42 on Boston Brook at Peabody Street. The average score for tributary sites was 147 . 
A.

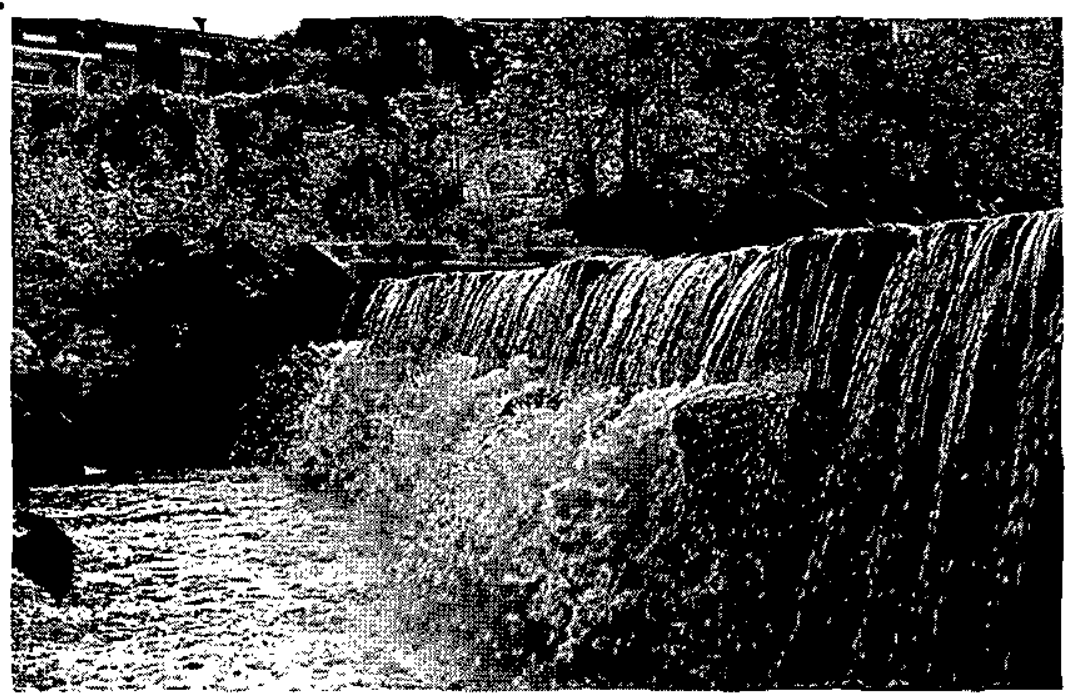

c.

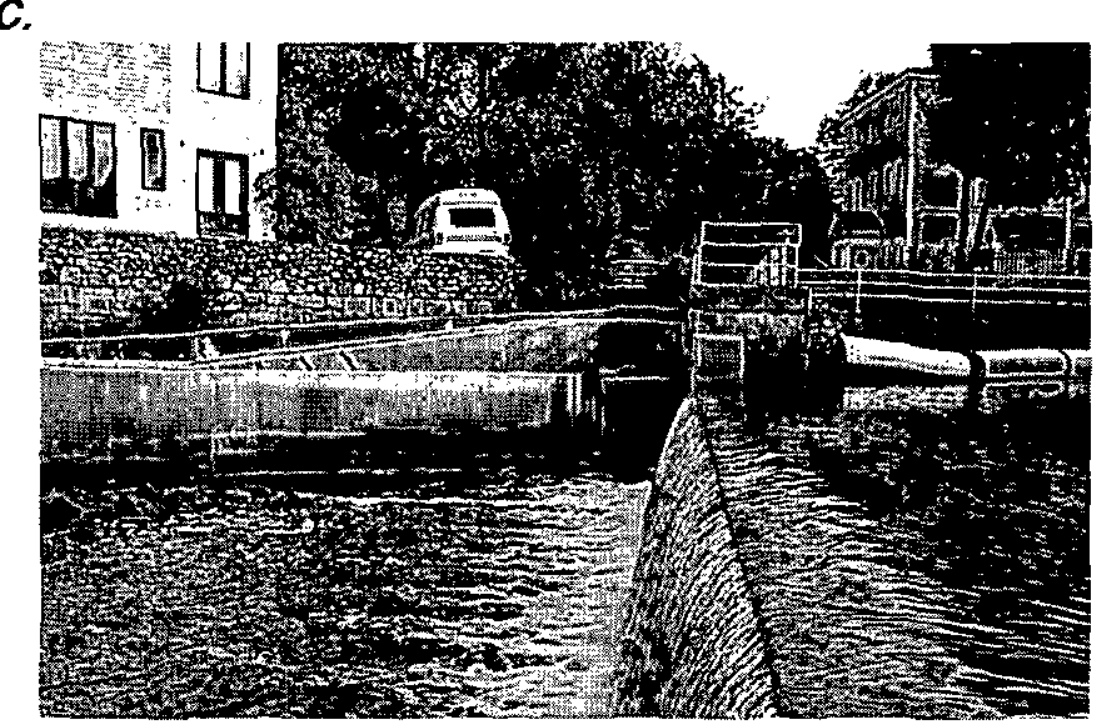

Figure 15. (A) South Middleton Dam, Middleton, view of right bank; (B) Willowdale Dam, Ipswich/Hamilton, upstream view; and $(C)$ Sylvania Dam, with fish ladder, view of right bank, Ipswich River, Massachusetts.
B.

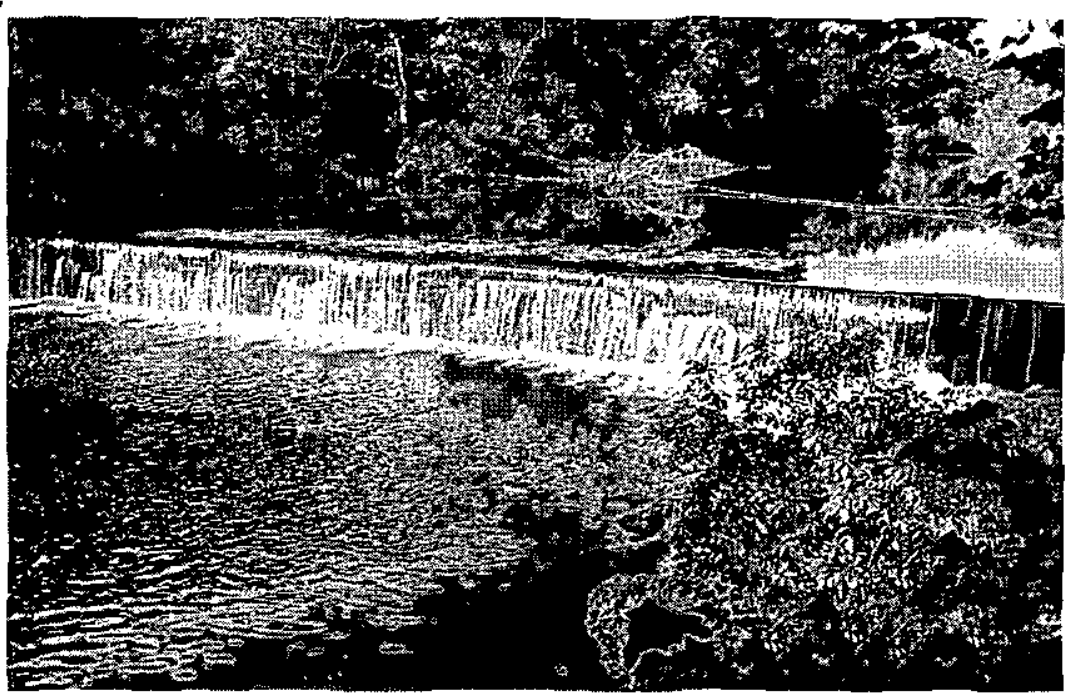


Table 10. U.S. Environmental Protection Agency Rapid Bioassessment Protocol habitat scores for Ipswich River, Massachusetts, study reaches, 1998-99

[Habitat parameter: Habitat parameters in parentheses are used for high-gradient stream reaches. USGS Habitat Site ID: First letter of stream name and downstream order along identified stream; H, high gradient; L, low gradient. ID, identifier; USGS, U.S. Geological Survey]

\begin{tabular}{|c|c|c|c|c|c|c|c|c|c|c|c|c|c|c|c|c|c|c|c|c|c|c|}
\hline \multirow[b]{2}{*}{ Habitat parameter } & \multicolumn{21}{|c|}{ USGS Habitat site ID } & \multirow{2}{*}{$\begin{array}{c}\text { Main- } \\
\text { stem } \\
\text { average }\end{array}$} \\
\hline & $\begin{array}{l}12 \\
(L)\end{array}$ & $\begin{array}{l}18 \\
(L)\end{array}$ & $\begin{array}{l}110 \\
(\mathrm{~L})\end{array}$ & $\begin{array}{l}111 \\
\text { (L) }\end{array}$ & $\begin{array}{l}12 \\
(L)\end{array}$ & $\begin{array}{l}117 \\
\text { (L) }\end{array}$ & $\begin{array}{l}\text { I18 } \\
\text { (L) }\end{array}$ & $\begin{array}{l}120 \\
\text { (H) }\end{array}$ & $\begin{array}{l}123 \\
\text { (L) }\end{array}$ & $\begin{array}{l}124 \\
(L)\end{array}$ & $\begin{array}{l}125 \\
(L)\end{array}$ & $\begin{array}{l}126 \\
(L)\end{array}$ & $\begin{array}{l}127 \\
\text { (L) }\end{array}$ & $\begin{array}{l}129 \\
(L)\end{array}$ & $\begin{array}{l}\text { I31 } \\
\text { (L) }\end{array}$ & $\begin{array}{l}\text { I32 } \\
\text { (L) }\end{array}$ & (L) & $\begin{array}{l}134 \\
\text { (L) }\end{array}$ & $\begin{array}{l}135 \\
(L)\end{array}$ & $\begin{array}{l}137 \\
\text { (L) }\end{array}$ & $\begin{array}{l}138 \\
(\mathrm{H})\end{array}$ & \\
\hline Epifaunal substrate/Available cover & 13 & 13 & 13 & 15 & 20 & 13 & 20 & 18 & 15 & 16 & 18 & 16 & 11 & 18 & 16 & 19 & 13 & 18 & 17 & 18 & 18 & 16.1 \\
\hline $\begin{array}{l}\text { Pool substrate characterization } \\
\text { (Embeddedness) }\end{array}$ & 13 & 13 & 18 & 15 & 20 & 13 & 20 & 18 & 13 & 17 & 18 & 19 & 13 & 18 & 18 & 17 & 13 & 15 & 18 & 18 & 19 & 16.5 \\
\hline $\begin{array}{l}\text { Pool variability (Velocity-depth } \\
\text { regime) }\end{array}$ & 18 & 8 & 13 & 10 & 19 & 13 & 6 & 10 & 13 & 10 & 11 & 10 & 8 & 8 & 8 & 10 & 8 & 11 & 8 & 10 & 16 & 10.9 \\
\hline Sediment deposition & 18 & 13 & 13 & 13 & 20 & 13 & 20 & 15 & 18 & 18 & 19 & 13 & 13 & 9 & 19 & 19 & 13 & 18 & 20 & 20 & 20 & 16.4 \\
\hline Channel flow status & 20 & 16 & 16 & 18 & 19 & 17 & 20 & 16 & 16 & 16 & 18 & 15 & 16 & 18 & 15 & 16 & 15 & 18 & 15 & 16 & 15 & 16.7 \\
\hline Channel alteration & 20 & 13 & 19 & 20 & 18 & 14 & 13 & 15 & 19 & 20 & 13 & 13 & 20 & 19 & 12 & 20 & 16 & 20 & 13 & 15 & 13 & 16.4 \\
\hline $\begin{array}{l}\text { Channel sinuosity (Frequency of } \\
\text { riffles) }\end{array}$ & 15 & 8 & 15 & 8 & 8 & 5 & 5 & 8 & 8 & 10 & 6 & 8 & 8 & 10 & 7 & 13 & 8 & 11 & 8 & 8 & 16 & 9.2 \\
\hline Bank stability & 20 & 18 & 18 & 20 & 16 & 20 & 20 & 19 & 20 & 20 & 20 & 20 & 18 & 11 & 14 & 17 & 17 & 20 & 17 & 18 & 20 & 18.2 \\
\hline Vegetative protection & 20 & 20 & 20 & 20 & 20 & 20 & 20 & 19 & 20 & 20 & 20 & 20 & 20 & 20 & 19 & 20 & 19 & 20 & 20 & 20 & 18 & 19.8 \\
\hline Riparian vegetative zone width & 20 & 20 & 18 & 20 & 18 & 19 & 14 & 19 & 20 & 20 & 20 & 20 & 20 & 20 & 18 & 19 & 19 & 20 & 20 & 20 & 18 & 19.1 \\
\hline Total score & 177 & 142 & 163 & 159 & 178 & 147 & 158 & 157 & 162 & 167 & 163 & 154 & 147 & 151 & 146 & 170 & 141 & 171 & 156 & 163 & 173 & 159.3 \\
\hline
\end{tabular}

\begin{tabular}{|c|c|c|c|c|c|c|c|c|c|}
\hline \multirow[b]{2}{*}{ Habitat parameter } & \multicolumn{8}{|c|}{ USGS Habitat site ID } & \multirow{2}{*}{$\begin{array}{l}\text { Tributary } \\
\text { average }\end{array}$} \\
\hline & $\begin{array}{l}\text { S39 } \\
(H)\end{array}$ & $\begin{array}{c}\text { M40 } \\
\text { (L) }\end{array}$ & $\begin{array}{c}\text { B42 } \\
\text { (L) }\end{array}$ & $\begin{array}{l}\mathrm{F43} \\
\text { (H) }\end{array}$ & $\begin{array}{l}\text { F44 } \\
\text { (H) }\end{array}$ & $\begin{array}{l}\text { F45 } \\
\text { (H) }\end{array}$ & $\begin{array}{l}\mathrm{H} 47 \\
\text { (H) }\end{array}$ & $\begin{array}{l}\mathrm{H} 48 \\
(\mathrm{~L})\end{array}$ & \\
\hline Epifaunal substrate/Available cover & 6 & 18 & 8 & 4 & 8 & 12 & 13 & 13 & 10.3 \\
\hline $\begin{array}{l}\text { Pool substrate characterization } \\
\text { (Embeddedness) }\end{array}$ & 7 & 15 & 8 & 18 & 17 & 18 & 20 & 17 & 15.0 \\
\hline $\begin{array}{l}\text { Pool variability (Velocity-depth } \\
\text { regime) }\end{array}$ & 4 & 13 & 8 & 9 & 13 & 13 & 10 & 12 & 10.3 \\
\hline Sediment deposition & 18 & 13 & 8 & 19 & 13 & 19 & 18 & 13 & 15.1 \\
\hline Channel flow status & 4 & 18 & 5 & 3 & 8 & 8 & 8 & 12 & 8.3 \\
\hline Channel alteration & 19 & 20 & 13 & 19 & 19 & 18 & 13 & 20 & 17.6 \\
\hline $\begin{array}{l}\text { Channel sinuosity (Frequency of } \\
\text { riffles) }\end{array}$ & 12 & 18 & 8 & 19 & 14 & 17 & 18 & 19 & 15.6 \\
\hline Bank stability & 20 & 18 & 8 & 19 & 17 & 18 & 20 & 19 & 17.4 \\
\hline Vegetative protection & 20 & 20 & 16 & 20 & 19 & 18 & 20 & 20 & 19.1 \\
\hline Riparian vegetative zone width & 18 & 20 & 18 & 20 & 16 & 20 & 18 & 20 & 18.8 \\
\hline Total score & 128 & 173 & 100 & 150 & 144 & 161 & 158 & 165 & 147.4 \\
\hline
\end{tabular}


The stream channel and riparian zone were relatively unaltered at many of the study sites on the mainstem Ipswich and tributaries. Consequently, metrics associated with vegetative protection, riparian vegetative zone width, bank stability, and channel alteration had high mean scores, averaging 19.6, 19, 18, and 16.8, respectively. Because the Ipswich is predominantly a sand-bed stream, scores for pool substrate characterization and sediment deposition metrics were slightly lower, averaging 16.1 and 16 , respectively. The frequency of bends and riffles, and pool-variability velocity-depth regime metrics had the lowest mean score, averaging 10.7 and 11 , respectively. These low scores are not unexpected, however, because the Ipswich River and its tributaries are predominantly low-gradient stream systems. Scores for channel-flow status and available cover averaged 14.5 and 14.4, respectively, for all sites.

Assessments made during the relatively wet 1998 indicate that habitat is not a limiting factor in the Ipswich River in years when the river maintains flow. Scores for flow-related metrics that were assessed at mainstem sites in 1998, a relatively wet year, differ from those that were assessed at tributary sites in 1999 , a relatively dry year. Channel-flow status, available cover, and velocity/depth regime averaged 16.7, 16.1, and 11.9 at the mainstem sites, and 8.3,10.3, and 10.3 at tributary sites, respectively. Habitat assessments made at different sites and times may not be directly comparable because of differences in flow conditions. Habitat assessments were conducted during mid-summer, while the streams were still flowing, and would have scored considerably lower if conducted during times when the stream was dry. For example, a riffle downstream of the South Middleton Dam scored 168 on August 28, 1998, but scored only 111 on July 20, 1999 , a period during which the reach was dry except for an isolated pool downstream of the dam.

\section{FISH-COMMUNITY ASSESSMENT}

Fish communities from a range of habitat types were assessed to characterize fish-species diversity, relative abundance, and length frequency distribution in the Ipswich River and in selected tributaries. To assess the effect of flow alterations on the fish community of the Ipswich River, the composition of the Ipswich River fish community was compared to the composition of fish communities in the Quinebaug and Lamprey Rivers, and to a target fish community being developed to represent the fish community in a natural river in southern New England (M.B. Bain, U.S. Geological Survey, written commun., 2000). To assess aquatic health, fish-community data also were applied to indexes of biotic integrity developed for cold-water, mixed, and warm-water streams in New England.

\section{8-99 Fish Sampling}

Fish were collected in the mainstem Ipswich River in 1998 from the headwaters in Wilmington, to the non-tidal portion of the river in Ipswich, and in 1999 in the Boston Brook, Fish Brook, Howlett Brook, Martins Brook, Norris Brook, and Skug River tributaries from North Reading to Ipswich. One site on the mainstem Ipswich River below the south Middleton Dam in Middleton was sampled in 1998 and 1999. From August 19 to September 29, 1998, 27 fish collections were made on the mainstem. More than $9,840 \mathrm{ft}$ of stream were sampled with site lengths varying from 200 to $820 \mathrm{ft}$. The electrofishing effort, as measured by the duration of electroshocking time, totaled $48,199 \mathrm{sec}$ with each collection ranging from 1,001 to $3,558 \mathrm{sec}$ (table 11).

In the mainstem, 4,745 fish were collected comprising 21 different species. The average number of fish collected at each site was 176 , but ranged from 35 to 425. The average number of species identified per site was 10 , but ranged from 4 to 17 . Flows at the Ipswich gage during the sampling period ranged from 12 to $83 \mathrm{ft}^{3} / \mathrm{s}$. The fish communities in the mainstem were dominated by three species; by number, redfin pickerel composed 41 percent, American eel composed 22 percent, and pumpkinseed composed 10 percent (table 12). The remaining 18 species each made up less than 5 percent of the sample. Length frequency distributions, although not used in the analysis, were gathered as a part of the MDFW sampling protocol and can be found in Appendix C.

Fish were collected in the tributaries of the Ipswich River in 1999 from North Reading, Mass., to Topsfield, Mass. From July 13 to July 21, a total of 10 fish collections were made in 6 tributaries. More than $3,900 \mathrm{ft}$ of stream were sampled, with site lengths varying from 230 to $640 \mathrm{ft}$ (excluding site number 3, whose length was only $16 \mathrm{ft}$ because of limited access). The electrofishing effort totaled $12,171 \mathrm{sec}$, with each site ranging from 350 to $1,927 \mathrm{sec}$. 
Table 11. Fish sampling date, electroshocking effort, reach length, on the mainstem in 1998 and tributaries in 1999, Ipswich River, Massachusetts

[Habitat Site ID: First letter of stream name and downstream order along identified stream. Fish: Number of fish captured at each site. Species: Number of species of fish captured at each site. Effort: Amount of time of electrofishing effort (Smith-Root model 12-B electroshocker used except where noted). Length: Length of stream sampled for fish. ID, identifier; MDFW, Massachusetts Division of Fisheries and Wildlife; USGS, U.S. Geological Survey; $\mathrm{m}$, meter; sec., second --, not measured]

\begin{tabular}{|c|c|c|c|c|c|c|c|c|}
\hline $\begin{array}{l}\text { USGS } \\
\text { habitat } \\
\text { Site ID }\end{array}$ & $\begin{array}{c}\text { MDFW } \\
\text { ID }\end{array}$ & Date & Stream Name & Town & Fish & Species & $\begin{array}{l}\text { Effort } \\
\text { (sec.) }\end{array}$ & $\begin{array}{l}\text { Length } \\
\text { (m) }\end{array}$ \\
\hline \multicolumn{9}{|c|}{ Ipswich River } \\
\hline $\mathrm{I} 2$ & 11 & $9-01-98$ & lpswich River & Wilmington & 190 & 4 & 1,422 & 130 \\
\hline 18 & 1 & $8-19-98$ & Ipswich River & Reading/North Reading & 162 & 9 & 3,536 & 182 \\
\hline 19 & 3 & $8-20-98$ & Ipswich River & North Reading & 114 & 8 & 2,419 & 100 \\
\hline $\mathrm{I} 9 \mathrm{a}$ & 2 & $8-19-98$ & Ipswich River & Reading/North Reading & 35 & 6 & 2,189 & 100 \\
\hline $\mathrm{I} 10$ & 4 & $8-20-98$ & Ipswich River & North Reading & 40 & 7 & 1,535 & 69 \\
\hline III & 7 & $8-27-98$ & Ipswich River & North Reading & 76 & 8 & 1,689 & 129 \\
\hline 112 & 6 & $8-27-98$ & Ipswich River & North Reading & 64 & 7 & 2,005 & 103 \\
\hline $\mathrm{I} 14^{\mathrm{l}}$ & 23 & $9-23-98$ & Ipswich River & Reading & 323 & 12 & 1,573 & -- \\
\hline $\mathrm{I} 15^{2}$ & 26 & $9-23-98$ & Ipswich River & Reading & 97 & 8 & -- & -- \\
\hline I17 & 14 & $9-03-98$ & Ipswich River & North Reading & 120 & 9 & 2,031 & 141 \\
\hline I18 & 8 & $8-28-98$ & Ipswich River & Middleton & 250 & 15 & 2,035 & 124 \\
\hline I19 & 42 & $7-20-99$ & Ipswich River & South Middleton & 145 & 17 & 1,156 & 124 \\
\hline $\mathrm{I} 20$ & 5 & $8-21-98$ & Ipswich River & Peabody/Middleton & 132 & 13 & 3,558 & 251 \\
\hline $\mathrm{I} 23$ & 9 & $8-28-98$ & Ipswich River & Middleton & 134 & 9 & 1,766 & 61 \\
\hline $\mathrm{I} 24$ & 10 & $8-31-98$ & Ipswich River & Middleton & 231 & 12 & 2,119 & 89 \\
\hline $\mathrm{I} 25$ & 12 & $9-01-98$ & Ipswich River & Middleton & 224 & 11 & 2,151 & 97 \\
\hline $\mathrm{I} 26$ & 15 & $9-03-98$ & Ipswich River & Middleton & 292 & 11 & 2,251 & 134 \\
\hline $\mathrm{I} 27$ & 13 & $9-01-98$ & Ipswich River & Middleton & 169 & 12 & 1,789 & 95 \\
\hline $\mathrm{I} 29$ & 16 & $9-04-98$ & Ipswich River & Topsfield & 425 & 7 & 1,274 & 127 \\
\hline 131 & 17 & $9-04-98$ & Ipswich River & Topsfield & 215 & 13 & 1,611 & 127 \\
\hline $\mathrm{I} 32$ & 24 & $9-29-98$ & Ipswich River & Topsfield & 175 & 13 & 1,001 & 81 \\
\hline $\mathrm{I} 33$ & 19 & $9-15-98$ & Ipswich River & Topsfield & 182 & 10. & 1,350 & 149 \\
\hline 134 & 22 & $9-17-98$ & Ipswich River & Topsfield & 224 & 9 & 1,253 & 130 \\
\hline $\mathrm{I} 35$ & 18 & $9-15-98$ & Ipswich River & Ipswich/Hamilton & 232 & 14 & 1,818 & 173 \\
\hline 136 & 20 & $9-15-98$ & Ipswich River & Topsfield & 63 & 8 & 1,144 & 74 \\
\hline 137 & 25 & $9-29-98$ & Ipswich River & Hamilton/Ipswich & 262 & 12 & 1,960 & 140 \\
\hline $\mathrm{I} 38$ & 21 & $9-16-98$ & Ipswich River & Ipswich/Hamilton & 169 & 11 & 1,564 & 133 \\
\hline
\end{tabular}

\begin{tabular}{|c|c|c|c|c|c|c|c|c|}
\hline \multicolumn{9}{|c|}{ Tributaries } \\
\hline S39 & 45 & $7-21-99$ & Skug River & North Andover & 201 & 9 & 561 & 126 \\
\hline M40 & 43 & $7-20-99$ & Martins Brook & North Reading & 139 & 9 & 1,068 & 127 \\
\hline N41 & 41 & $7-15-99$ & Norris Brook & Peabody & 80 & 5 & 350 & 5 \\
\hline B42 & 38 & 7-14-99 & Boston Brook & Middleton & 133 & 12 & 1,918 & 196 \\
\hline F43 & 44 & $7-21-99$ & Fish Brook & North Andover & 139 & 9 & 1,336 & 130 \\
\hline F44 & 39 & $7-15-99$ & Fish Brook & Boxford & 172 & 9 & 1,389 & 120 \\
\hline F45 & 40 & $7-15-99$ & Fish Brook & Boxford & 133 & 8 & 1,927 & 187 \\
\hline H46 & 35 & $7-13-99$ & Howlett Brook & Topsfield & 77 & 6 & 831 & 70 \\
\hline H47 & 37 & $7-13-99$ & Howlett Brook & Topsfield & 101 & 11 & 1,376 & 100 \\
\hline $\mathrm{H} 48$ & 36 & 7-13-99 & Howlett Brook & Topsfield & 42 & 5 & 1,415 & 150 \\
\hline
\end{tabular}


Table 12. Mean length, number, and percent of total fish by species collected in the mainstem in 1998 and tributaries in 1999 , Ipswich River, Massachusetts

[Species: Species are ranked by percent of total. Standard deviation: Standard deviation for the mean length. Number collected: Number of fish collected. Percent of total: Percent of the total number of fish collected for each species. mm, millimeter; <, actual value is less than value shown; --, not applicable]

\begin{tabular}{|c|c|c|c|c|c|c|c|c|c|}
\hline Species & $\begin{array}{c}\text { Mean } \\
\text { length } \\
(\mathrm{mm})\end{array}$ & $\begin{array}{c}\text { Standard } \\
\text { deviation } \\
(\mathrm{mm})\end{array}$ & $\begin{array}{l}\text { Number } \\
\text { collected }\end{array}$ & $\begin{array}{l}\text { Percent } \\
\text { of total }\end{array}$ & Species & $\begin{array}{c}\text { Mean } \\
\text { length } \\
\text { (mm) }\end{array}$ & $\begin{array}{c}\text { Standard } \\
\text { deviation } \\
(\mathbf{m m})\end{array}$ & $\begin{array}{l}\text { Number } \\
\text { collected }\end{array}$ & $\begin{array}{l}\text { Percent } \\
\text { of total }\end{array}$ \\
\hline \multicolumn{5}{|c|}{ Ipswich River } & \multicolumn{5}{|c|}{ Tributaries } \\
\hline Redfin pickerel & 114 & 30 & 1,945 & 41 & American eel & 234 & 77 & 245 & 20 \\
\hline American eel & 262 & 81 & 1,026 & 22 & Pumpkinseed & 80 & 15 & 213 & 18 \\
\hline Pumpkinseed & 81 & 23 & 489 & 10 & Redfin pickerel & 129 & 23 & 212 & 17 \\
\hline Redbreast sunfish & 88 & 31 & 236 & 5 & Fallfish & 55 & 47 & 145 & 12 \\
\hline Bluegill & 99 & 33 & 213 & 4 & Creek chubsucker & 97 & 27 & 72 & 6 \\
\hline Chain pickerel & 129 & 77 & 196 & 4 & Largemouth bass & 51 & 15 & 72 & 6 \\
\hline Yellow perch & 127 & 41 & 132 & 3 & Golden shiner & 98 & 16 & 51 & 4 \\
\hline Creek chubsucker & 151 & 65 & 115 & 2 & Bluegill & 81 & 29 & 46 & 4 \\
\hline White sucker & 206 & 164 & 95 & 2 & Chain pickerel & 101 & 45 & 40 & 3 \\
\hline Yellow bullhead & 148 & 48 & 74 & 1 & Sea lamprey & 114 & . 34 & 25 & 2 \\
\hline Sea lamprey & 139 & 24 & 49 & 1 & White sucker & 138 & 28 & 19 & 2 \\
\hline Golden shiner & 119 & 38 & 43 & 1 & Banded sunfish & 65 & 10 & 17 & 1 \\
\hline Largemouth bass & 100 & 67 & 38 & 1 & Green sunfish & 103 & 27 & 15 & 1 \\
\hline Swamp darter & 44 & 8 & 29 & 1 & Brown bullhead & 122 & 38 & 13 & 1 \\
\hline Brown bullhead & 176 & 63 & 17 & $<1$ & Yellow perch & 122 & 10 & 10 & 1 \\
\hline Green sunfish & 91 & 22 & 14 & $<1$ & Swamp darter & 48 & 6 & 8 & 1 \\
\hline Banded sunfish & 56 & 16 & 13 & $<1$ & Yellow bullhead & 152 & 35 & 6 & $<1$ \\
\hline Fallfish & 113 & 29 & 11 & $<1$ & Brook trout & 179 & 85 & 3 & $<1$ \\
\hline Brown trout & 268 & 19 & 6 & $<1$ & Redbreast sunfish & 90 & 9 & 3 & $<1$ \\
\hline Black crappie & 172 & 42 & 3 & $<1$ & Brown trout & 228 & 11 & 2 & $<1$ \\
\hline Rainbow trout & 304 & -- & 1 & $<1$ & All Species & 123 & 78 & 1,217 & 100 \\
\hline All Species & 148 & 89 & 4,745 & 100 & & & & & \\
\hline
\end{tabular}

In the tributaries, 1,217 fish were collected comprising 20 different species. The average number of fish collected at each site was 122 , but ranged from 42 to 201. The average number of different species collected per site was 8 , but ranged from 5 to 12 . The fish community in the tributaries, as in the mainstem, was dominated by a few species. By number, American eel composed 20 percent, pumpkinseed represented 18 percent, redfin pickerel composed 17 percent, and fallfish made up 12 percent (table 12). The remaining 16 species each made up less than 6 percent of the sample.

Although an extensive effort was made to sample different habitats and identify all fish species in the Ipswich River Basin, it is possible that some fish species were not collected. For example, in unrelated sampling efforts, staff from the New England Aquarium reported the presence of bridled shiner in Fish Brook during 1999 (Richard Tomczyk, Executive Office of Environmental Affairs, written commun., 1999), and the MDFW documented the presence of brook trout in Gravelly Brook during 2000 .

\section{Index of Biotic Integrity}

Fish-community data for 1998 were entered into Indexes of Biotic Integrity (IBIs) developed for cold-water streams in Connecticut (Jacobson, 1994) and for warm-water and mixed-water streams in Vermont (Richard Langdon, Vermont Department of Environmental Conservation, written commun., 1999), Results show scores derived from the Connecticut cold-water IBI ranged from 8 (poor) to 14 (poor) and 
averaged 9.0 (poor); scores from the Vermont warm-water IBI ranged from 15 (poor) to 27 (good) and averaged 23.7 (good); and scores from the Vermont mixed-water IBI ranged from 27 (good) to 35 (very good) and averaged 31.6 (good to very good). Although these scores could be used to indicate that, under current stream conditions, the Ipswich River better supports a warm-water or mixed-water fish community than a cold-water fish community, they should not be used to indicate that the Ipswich fish community is healthy because the IBI scores only were calculated for sites that had water. Inclusion of sites that were dry and had no fish would have resulted in considerably lower scores than those included in this analysis.

The Vermont and Connecticut IBIs are not sensitive to characteristics of the Ipswich River fish community that appear to be related to recurrent low flows, such as a high percentage of macrohabitat generalist species, missing age classes, and the predominance of small pioneering fish species that are the first to return to reaches that were previously dry. Metrics that are sensitive to degradation created by recurrent low flows need to be developed, and could include the percentage of individuals in different habitat-use classifications; the percentage of individuals that are pioneering species; the length frequency distribution; the number of species having missing age classes; and the percentage biomass of fish.

\section{Fish-Community Description}

In accordance with habitat-use classifications developed by Bain (U.S. Geological Survey, written commun., 2000), fish species sampled in the Ipswich River were divided into one of three macrohabitat classes: macrohabitat generalists, fluvial dependents, and fluvial specialists (table 13). Fish in the Ipswich River mainstem consisted of 95 percent macrohabitat generalists, 4 percent fluvial dependent species, and 0.2 percent fluvial specialist species

(fig. 16). As a whole, the fish-community composition of the tributaries differed little from the mainstem; macrohabitat generalists accounted for 80.1 percent of the fish population, with
Table 13. Habitat-use classifications of fish in the Ipswich River Basin, Massachusetts

[Macrohabitat: FD, fluvial dependent; FS, fluvial specialist; MG, macrohabitat generalist. Pollution tolerance: $\mathrm{J}$, intolerant; $\mathbf{M}$, intermediate; T, tolerant. --, not classified]

\begin{tabular}{|c|c|c|c|c|}
\hline Common name & Genus & Species & $\begin{array}{l}\text { Macro- } \\
\text { habitat }\end{array}$ & $\begin{array}{l}\text { Pollution } \\
\text { tolerance }\end{array}$ \\
\hline American eel & Anguilla & rostrata & $\mathrm{MG}$ & $\mathrm{T}$ \\
\hline Banded sunfish & Enneacanthus & obesus & MG & -- \\
\hline Black crappie & Pomoxis & nigromaculatus & MG & M \\
\hline Bluegill & Lepomis & macrochirus & MG & $\mathrm{T}$ \\
\hline Bridle shiner & Notropis & bifrenatus & MG & 1 \\
\hline Brook trout & Salvelinus & fontinalis & FS & I \\
\hline Brown bullhead & Ameiurus & nebulosus & MG & $\mathrm{T}$ \\
\hline Brown trout & Salmo & trutta & FD & I \\
\hline Chain pickerel & Esox & niger & MG & M \\
\hline Creek chubsucker & Erimyzon & oblongus & FS & I \\
\hline Fallfish & Semotilus & corporalis & FS & M \\
\hline Golden shiner & Notemigonus & crysoleucas & MG & $T$ \\
\hline Green sunfish & Lepomis & cyanellus & MG & $T$ \\
\hline Largemouth bass & Micropterus & salmoides & MG & M \\
\hline Pumpkinseed & Lepomis & gibbosus & MG & M \\
\hline Rainbow trout & Oncorhynchus & mykiss & $\mathrm{FD}$ & 1 \\
\hline Redbreast sunfish & Lepomis & auritus & MG & M \\
\hline Redfin pickerel & Esox & americanus & MG & M \\
\hline Sea lamprey & Petromyzon & marinus & -- & -- \\
\hline Swamp darter & Etheostoma & fusiforme & MG & I \\
\hline White sucker & Catostomus & commersoni & FD & $\mathrm{T}$ \\
\hline Yellow bullhead & Ameiurus & natalis & MG & $\mathrm{T}$ \\
\hline Yellow perch & Perca & flavescens & MG & M \\
\hline
\end{tabular}

fluvial dependent species making up 8.2 percent, and fluvial specialists 11.7 percent (fig. 16). Thus, the fish community in the Ipswich River Basin could be described more as a warm-water pond fishery than a river fish community.

The percentage of fish in the three habitat-use classifications differed between tributaries. Only Howlett Brook, Martins Brook, and Fish Brook (fig. 17) had fish populations represented in all three habitat-use categories. Boston Brook and Norris Brook only had macrohabitat generalists. In Fish Brook, young-of-the-year (YOY) fallfish (less than $40 \mathrm{~mm}$ long) account for 75 percent of the fallfish sample. Generally, YOY fish are removed from the fish-community analyses because they are hard to identify and can skew the results. When YOY fallfish are removed from the community composition in Fish Brook, macrohabitat generalists dominate the community composition (63 percent), yielding a fish community that is similar to that found in other tributaries. 


\section{A. Ipswich River mainstem}

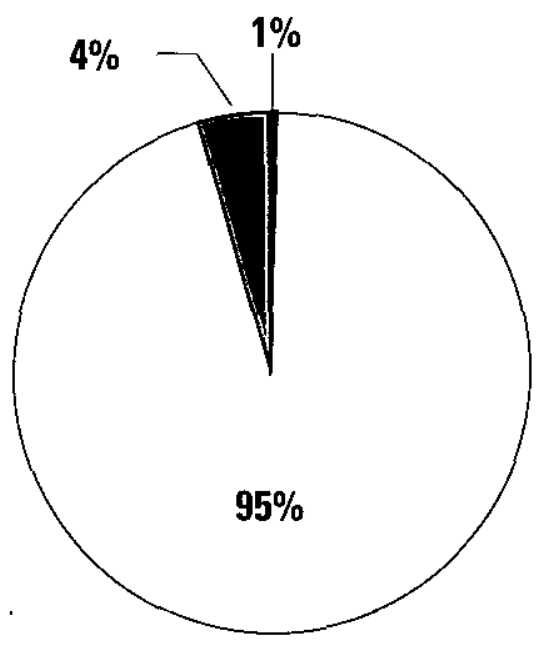

\section{B. Ipswich River tributaries}

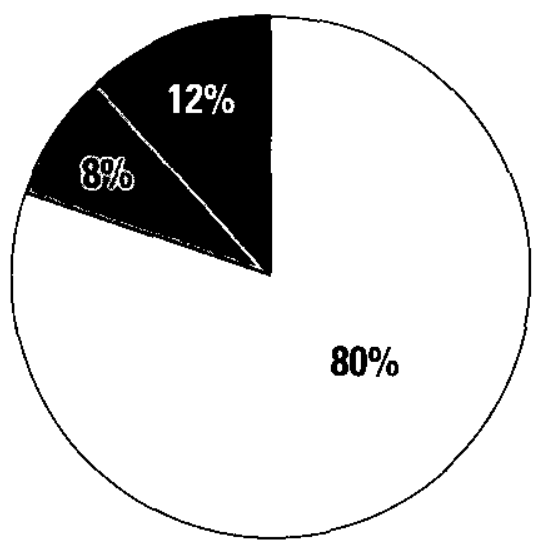

EXPLANATION

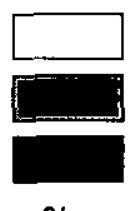

MACROHABITAT GENERALIST

FLUVIAL DEPENDENT

FLUVIAL SPECIALIST

$\%$ PERCENT OF TOTAL

Figure 16. Fish-species habitat classifications on the $(A)$ Mainstem in 1998, and (B) Tributaries in 1999, Ipswich River, Massachusetts.
Habitat-use classifications for the Ipswich River fish community were compared to habitat-use classifications for the Quinebaug River, Massachusetts, the Lamprey River, New Hampshire, and to a target fish community under development for the Quinebaug River (M.B. Bain, U.S. Geological Survey, written commun., 2000). Because the target fish community is under development, the expected proportions of individual species in the target fish community are subject to change; however, substantial changes in the overall habitat-use composition are not expected. The Quinebaug River is considered flow-impaired (M.B. Bain, U.S. Geological Survey, written commun., 2000) primarily by impoundments and flow releases. Despite this impairment, the Quinebaug River mainstem has an appreciably higher percentage of fluvial-dependent and fluvial-specialist species than the Ipswich River. Fish in the Quinebaug River mainstem, sampled at eight locations in 1999, had a population consisting of 36.7 percent macrohabitat generalists, 35.8 percent fluvial dependents, and 27.5 percent fluvial specialists (fig. 18A).

Habitat-use classifications for the Ipswich River fish community were compared to habitat-use classifications for the Lamprey River, a coastal river in New Hampshire about 30 mi north of the Ipswich River. Fish in the Lamprey River, collected from the Lamprey River and its tributaries during the summers of 1983 through 1985 (Scott Decker, New Hampshire Fish and Game Department, written commun., 2000), had a population consisting of 21.5 percent. macrohabitat generalists, 10.5 percent fluvial dependents, and 68.0 percent fluvial specialists (fig. 18B). The higher percentages of fluvial specialists in the Lamprey River and its tributaries can be attributed to higher numbers of fallfish and common white sucker than in the Ipswich River, and to the presence of some fluvial species (for example, blacknose dace and long-nose dace) that currently are not found in the Ipswich River.

Habitat-use classifications for the Ipswich River fish community also were compared to habitat-use classifications for a target fish community (M.B. Bain, U.S. Geological Survey, written commun., 2000) (fig. 19). Fish in the target fish community had a population consisting of 55 percent fluvial specialists, 27 percent fluvial dependents, and 18 percent macrohabitat generalists. Although a target fish community specific for the Ipswich River has not yet been finalized, comparisons to the Quinebaug and Lamprey Rivers and the New England target fish community indicate that the species composition of the Ipswich River and its tributaries would be expected to have substantially higher percentages of fluvial-dependent and fluvial specialist species. 
A. Howlett Brook

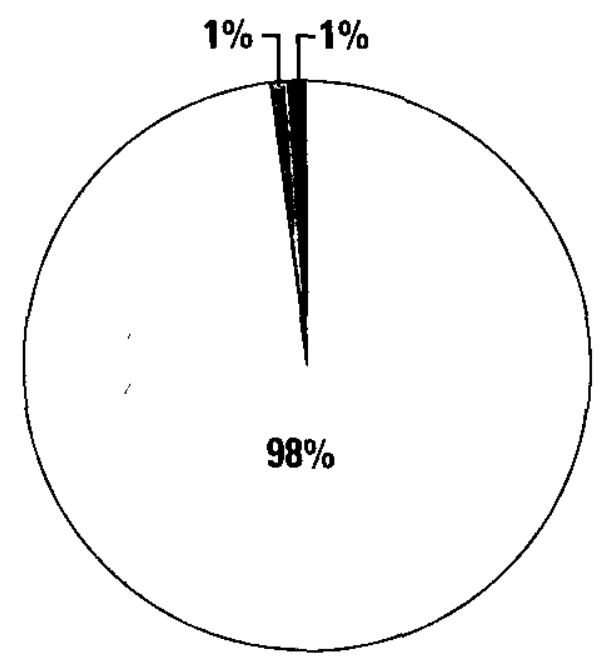

B. Martins Brook, young-of-the-year removed

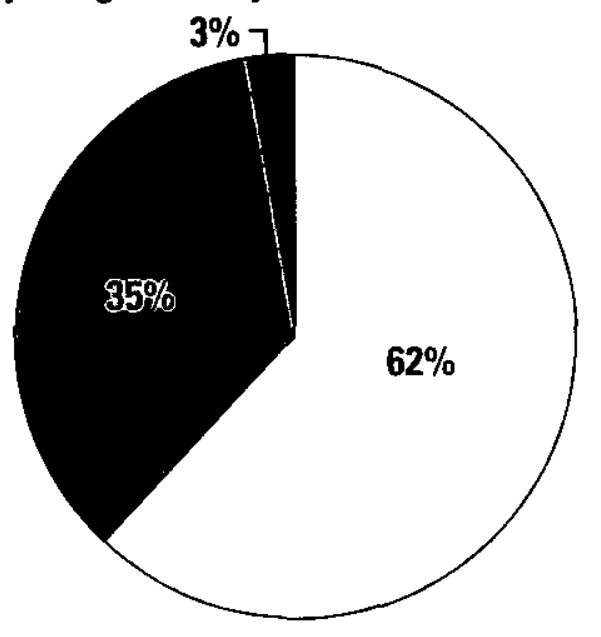

c. Fish Brook, young-of-the-year removed

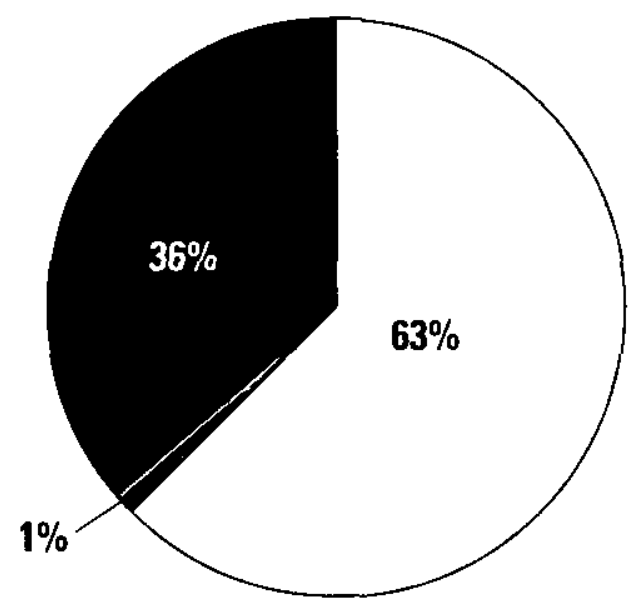

EXPLANATION

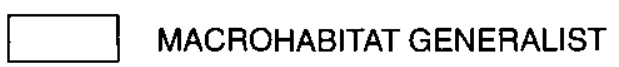

FLUVIAL DEPENDENT

FLUVIAL SPECIALIST

$\% \quad$ PERCENT OF TOTAL

Figure 17. Fish-species habitat classifications for tributaries to the Ipswich River, Massachusetts:

$(A)$ Howlett Brook, $(B)$ Martins Brook, young-of-year removed, $(C)$ Fish Brook, young-of-year removed. 


\section{A. Quinebaug River, Massachusetts}

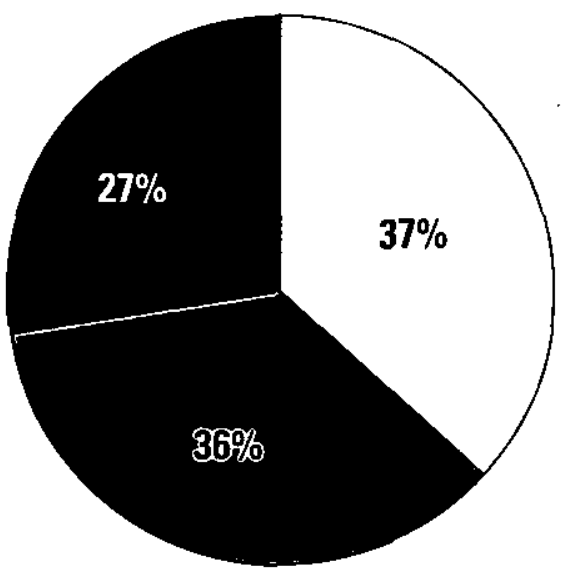

B. Lamprey River, New Hampshire

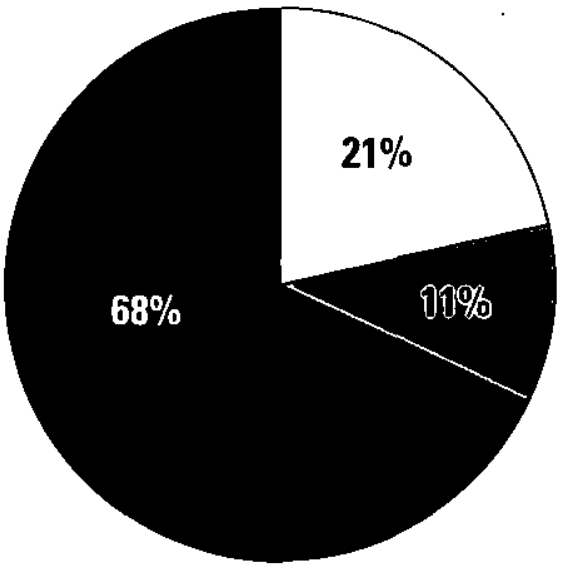

\section{EXPLANATION}

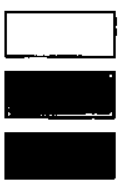

MACROHABITAT GENERALIST

FLUVIAL DEPENDENT

FLUVIAL SPECIALIST

$\%$ PERCENT OF TOTAL

Figure 18. Fish-species habitat classifications for two New England streams: (A) Quinebaug River, Massachusetts, and (B) Lamprey River, New Hampshire.
Target fish community fish-habitat classifications

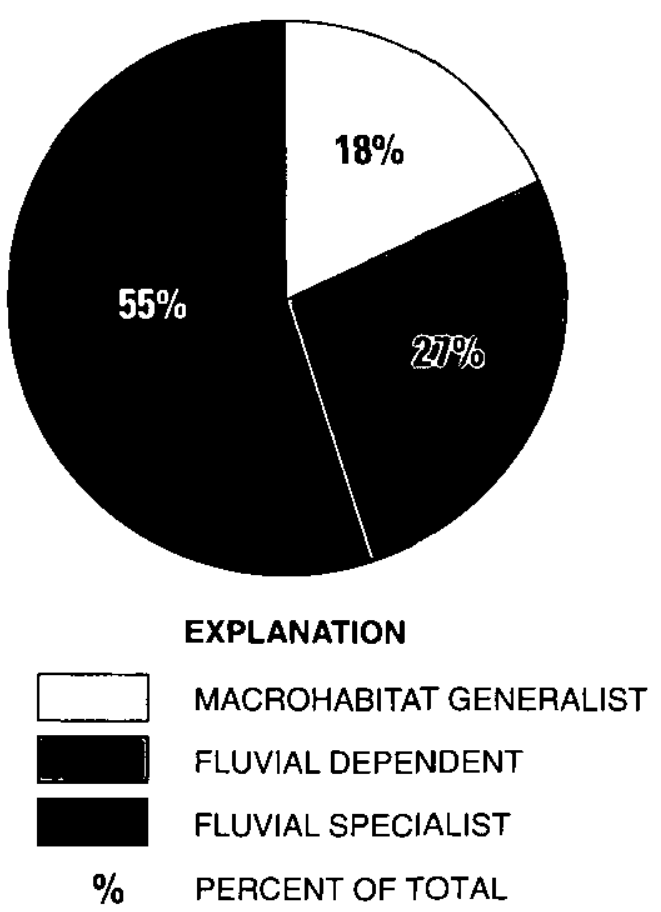

Figure 19. Target fish community, Quinebaug River, Massachusetts (M.B. Bain, U.S. Geological Survey, written commun., 2000).

\section{STREAMFLOW REQUIREMENTS FOR HABITAT PROTECTION}

Each of the methods for determining streamflow requirements for habitat protection produces different results. The Wetted-Perimeter and R2Cross methods require site-specific physical and hydrologic data, such as channel geometry, average velocity, and mean depth. These methods can be applied to ungaged sites once appropriate field data are collected. The Tennant and ABF methods are statistical measures of discharge-time series values, and require streamflow information from unregulated streams. Generally, the latter methods can be applied to gaged sites only if naturalized flow data are 
available, and can be applied to ungaged sites only by regionalizing flow statistics at gaged sites. Natural streamflow data are unavailable for the Ipswich River because water has been withdrawn continually upstream of the USGS gages, and some withdrawals predate establishment of the gages in the 1930s. For this report, daily discharges were obtained for the 1961-95 period with a basin-scale precipitation-runoff model of the Ipswich River (Zarriello and Ries, 2000), for a simulation representing no withdrawals, and a simulation representing average 1989-93 withdrawals. All scenarios used in this report simulated withdrawals under 1991 land-use conditions. These scenarios were chosen because the no-withdrawal simulation represents the best flow conditions that can be expected to support fish habitat, and because the HSPF model was calibrated to 1991 land use and to discharge data from 1989 to 1993 (P.J. Zarriello, U.S. Geological Survey, oral commun., 1999).

Streamflows were simulated for four riffles and the two streamflow-gaging stations: Ipswich River at South Middleton (01 101500) and Ipswich River near Ipswich (01102000). Because the four riffle sites were neither gaged nor used in model calibration, the simulation results at these sites are subject to greater uncertainty than those at the gaged sites. The Tennant and ABF methods, and Range of Variation Approach (RVA) were applied to all six study sites. Because the stream channels at the two gage sites were altered historically, and are altered today by the presence of upstream dams, the Wetted-Perimeter and R2Cross methods were applied only to the four ungaged riffle sites. To facilitate comparison between sites, streamflow requirements were normalized by drainage area to units of cubic feet per second per square mile.

\section{Critical Riffle Sites}

Four riffle reaches were identified as being critical areas for investigation of streamflow-habitat relations and for determination of streamflow requirements for habitat protection. The sites are located near Mill Street in North Reading/Reading, Log Bridge Road in Middleton/Danvers, Route 1 in Topsfield, and
Mill Road in Ipswich/Hamilton. These sites were chosen for determining streamflow standards for habitat protection because of their sensitivity to low flows, as shown in figure $20 A-F$. During declining flows, these riffles are among the first reaches to show habitat losses or develop fish passage problems, and are the first to dry.

\section{Mill Street, North Reading/Reading}

The riffle at Mill Street is just downstream of the Mill Street Bridge in North Reading/Reading. This site is one of the first reaches to have extreme low flows or to dry on the mainstem of the Ipswich River. The site is the first riffle downstream of the well fields for the Wilmington, Reading, and North Reading publicwater supplies. The riffle and bridge act as a hydraulic control and create a glide habitat upstream. Historically, this site may have included a dam, millpond, raceway, and mill in the vicinity of the bridge. It appears that Mill Street may have been built on top of the historic location of the mill dam. Consequently, the site has a highly altered stream channel and banks. The present channel is roughly trapezoidal in cross section, and the streambed is gravel, cobble and boulder. A small tile culvert extends from the base of the riffle to the wetland upstream of the bridge. Although there is a small flow from this culvert, the culvert is partially collapsed, and was not considered in a stage-discharge rating developed at the site.

\section{Log Bridge Road, Middleton/Danvers}

The riffle at Log Bridge Road consists of a sharp drop over a cobble-and-boulder rock control constructed from the collapsed stone abutments of an abandoned bridge. The site is the first control downstream of the Danvers public-water-supply well fields. Although these well fields were not in production during 1998 and 1999, the site historically had extreme low flows or went dry when those well fields were in operation (Kerry Mackin, Ipswich River Watershed Association, oral commun., 1999). 

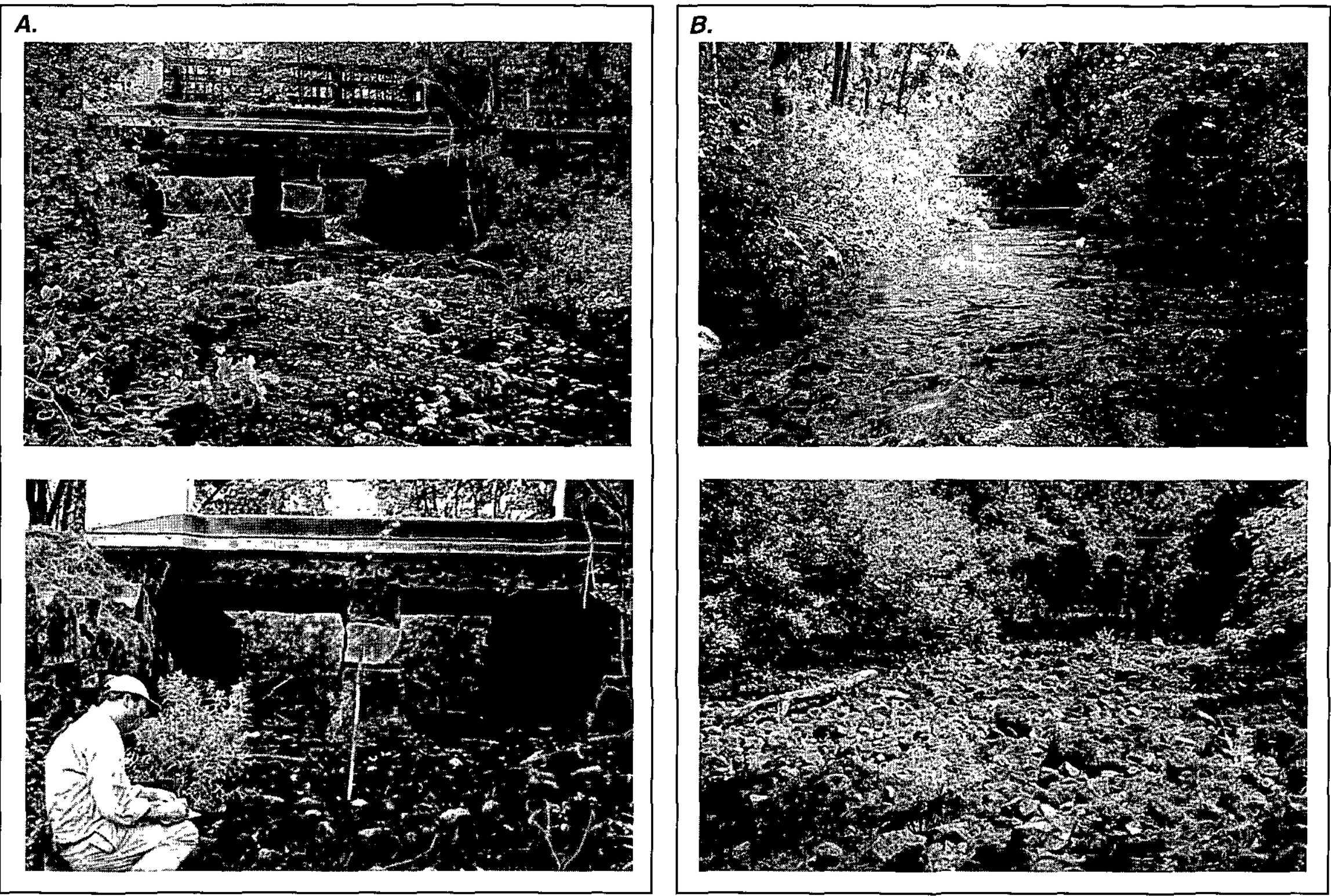

Figure 20. Stream channels at six critical riffle sites under flowing and dry (or nearly dry) conditions, Ipswich River, Massachusetts: $(A)$ Downstream of Mill Street, North Reading/Reading, upstream view; (B) Upstream of Russell Street and Middleton gage (01101500), Middleton, downstream view. 

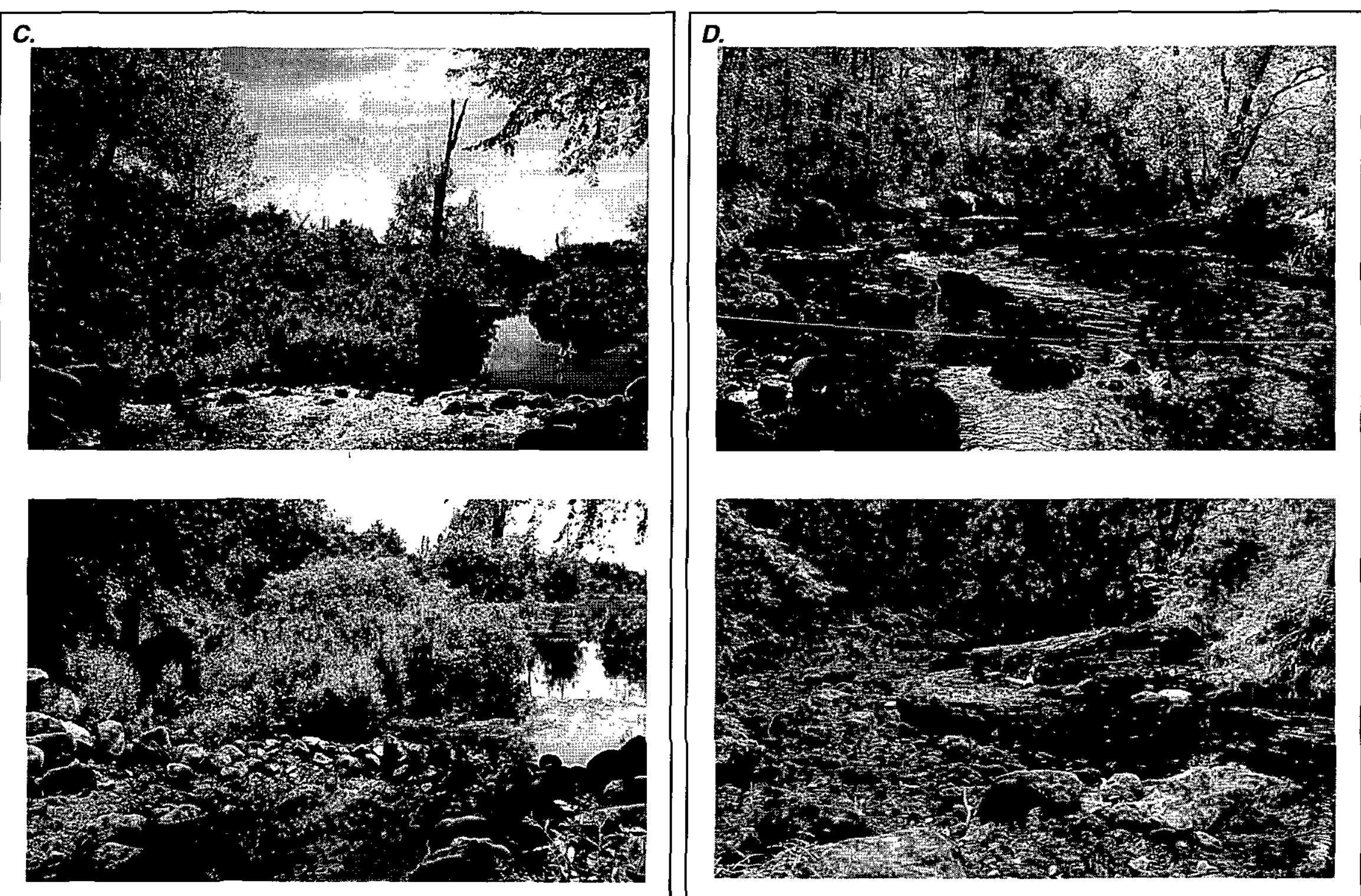

Figure 20. Stream channels at six critical riffle sites under flowing and dry (or nearly dry) conditions, lpswich River, Massachusetts: $(C)$ Log Bridge Road, Middleton/ Danvers, upstream view; $(D)$ Downstream of Route 1, Topsfield, upstream view-Continued. 

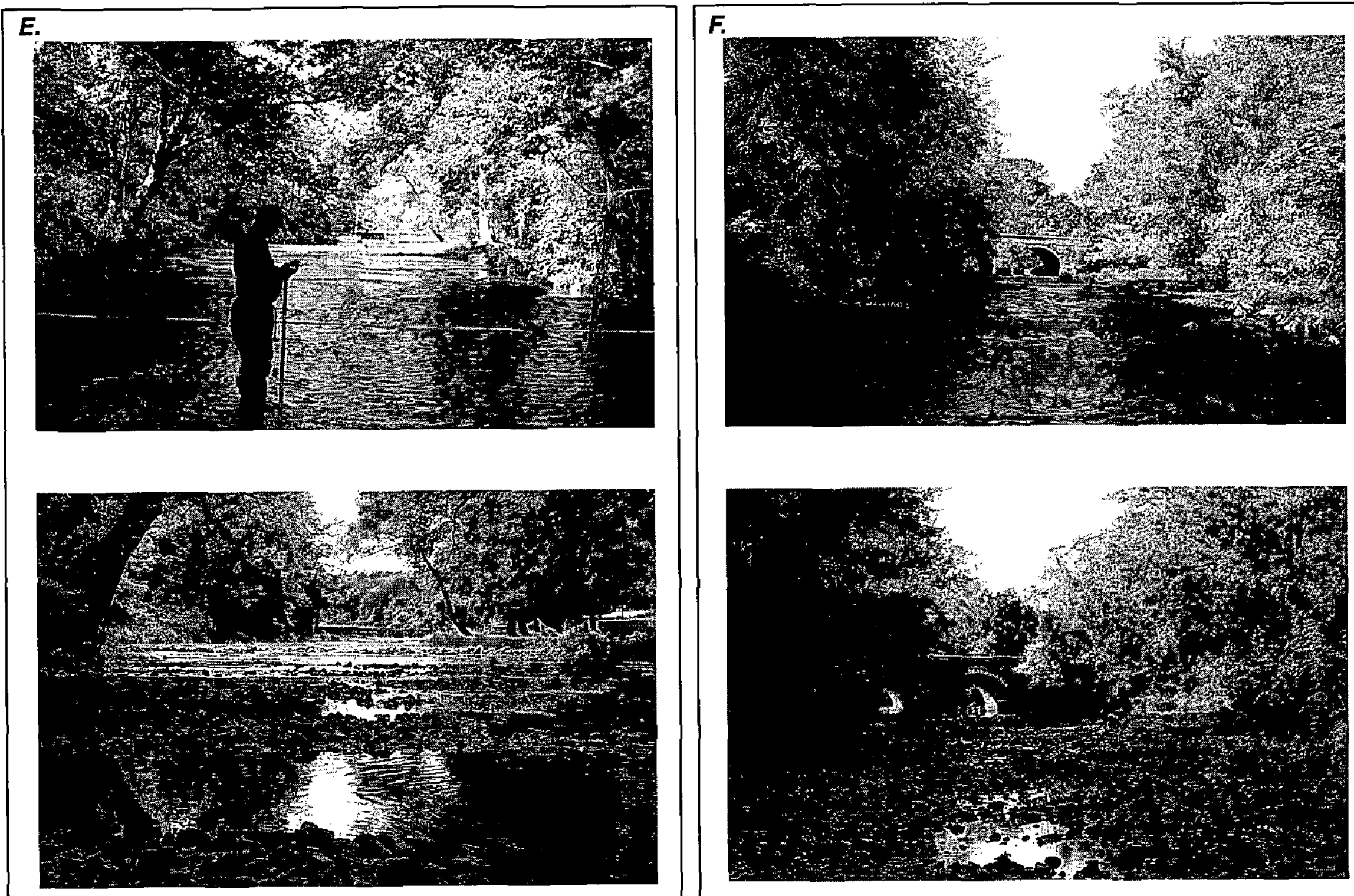

Figure 20. Stream channels at six critical riffle sites under flowing and dry (or nearly dry) conditions, lpswich River, Massachusetts: (E) Downstream of Ipswich gage (01102000), Ipswich/Hamilton, upstream view; $(A)$ Downstream of Mill Road, Ipswich/Hamilton, upstream view-Continued. 


\section{Route 1, Topsfield}

This riffle, located downstream of Route 1 adjacent to the Topsfield Fairgrounds, is one of two large natural riffles within the study area on the mainstem of the Ipswich River that do not have a nearby dam. The riffle is the control for a gaging station maintained by the Salem-Beverly Water Supply Board. The river at this site is about $40 \mathrm{ft}$ wide and is located on a meander that appears to be a natural channel. The streambed throughout the riffle consists of gravel, cobble, and boulders. The channel in the upper portion of the riffle has an asymmetric shape; the left side of the channel is deeper than the right side and conveys flow during low discharges, and a wide cobble-boulder shelf forms the right side of the channel.

\section{Mill Road, Ipswich/Hamilton}

The riffle downstream of Mill Road is the largest riffle on the mainstem of the Ipswich River within the study area. The landowners report that the site historically featured a crib dam and two mills. The only remaining structures are an old mill building on the right bank and the remnants of canals. A fragment of a canal is present on the left bank, but does not convey much flow because it is partially blocked at the upstream end and choked with brush. A canal in poor condition is on the right bank, and conveys streamflow that seeps through the stone foundation of the mill. This flow is returned to the channel at the base of the riffle. The elevation along the bottom of the canal on the right bank is about a foot lower than the streambed in the main channel. Consequently, during low-flow conditions, flow is split between the main channel and the canal, decreasing the depth of the riffle below the depth that would result were the canal not present. During extreme low flows, almost all of the streamflow is in the canal, and the riffle substrate becomes fully exposed in the main channel. The river at this site is about $90 \mathrm{ft}$ wide, and has been altered and possibly widened relative to its natural condition. The streambed throughout the riffle consists of gravel, cobble, and boulders.

\section{Tennant Method}

The mean annual flow ( $\mathrm{Q}_{\mathrm{MA}}$ ), the flow statistic used by this method, is summarized in table 14 for six mainstem Ipswich sites under average 1989-93 withdrawals and no withdrawals. The 40-, 30-, and 10-percent QMA values also are given in table 14. Normalized for drainage area at the six sites, the 40percent $\mathrm{Q}_{\mathrm{MA}}$ averaged $0.58\left(\mathrm{ft}^{3} / \mathrm{s}\right) / \mathrm{mi}^{2}$ under average 1989-93 withdrawals, and $0.67\left(\mathrm{ft}^{3} / \mathrm{s}\right) / \mathrm{mi}^{2}$ under no withdrawals; the 30 percent $\mathrm{QMA}_{\mathrm{MA}}$ averaged $0.44\left(\mathrm{ft}^{3} / \mathrm{s}\right) / \mathrm{mi}^{2}$ under average 1989-93 withdrawals, and $0.50\left(\mathrm{ft}^{3} / \mathrm{s}\right) / \mathrm{mi}^{2}$ under no withdrawals; and the 10-percent $Q_{\text {MA }}$ averaged $0.15\left(\mathrm{ft}^{3} / \mathrm{s}\right) / \mathrm{mi}^{2}$ under average 1989 93 withdrawals, and $0.17\left(\mathrm{ft}^{3} / \mathrm{s}\right) / \mathrm{mi}^{2}$ under no withdrawals. For purposes of comparisons between sites, the values for the QMA and the 30- and 10-percent values of the QMA are shown in figure 21 . These values are fairly constant, from upstream to downstream, because the QMA varies directly with drainage area (Dunne and Leopold, 1978; Ries and Friesz, 2000). Differences between values that represent habitat conditions under average 1989-93 withdrawals and no withdrawals average about 12 percent.

Table 14. The mean annual flow statistic used by the Tennant method and the streamflows representing summer habitat conditions determined by the 10- and 30-percent values of the mean annual flow, normalized for drainage area at six sites in the Ipswich River Basin, Massachusetts

[Site: locations are shown in figure 1. QMA: Mean annual flow, 40-percent QMA: Represents good summer habitat conditions. 30-percent $\mathbf{Q M A}_{\mathrm{MA}}$ : Represents fair summer habitat conditions. 10-percent $Q_{M A}$ : Represents poor summer habitat conditions. $\mathrm{ft}^{3} / \mathrm{s}$, cubic foot per second; $\left(\mathrm{ft}^{3} / \mathrm{s}\right) / \mathrm{mi}^{2}$, cubic foot per second per square mile]

\begin{tabular}{|c|c|c|c|c|}
\hline Site & $\underset{\left(\mathrm{ft}^{3} / \mathrm{s}\right)}{\mathrm{Q}_{\mathrm{MA}}}$ & $\begin{array}{c}\text { 40-percent } \\
\text { Q }_{M A} \\
\left(\mathrm{ft}^{3} / \mathrm{s}\right) / \mathrm{mi}^{2}\end{array}$ & $\begin{array}{c}\text { 30-percent } \\
\text { Q }_{M A} \\
\left(\mathrm{ft}^{3} / \mathrm{s}\right) / \mathbf{m i}^{2}\end{array}$ & $\begin{array}{c}\text { 10-percent } \\
Q_{M A} \\
\left(\mathrm{ft}^{3} / \mathrm{s}\right) / \mathrm{mi}^{2}\end{array}$ \\
\hline \multicolumn{5}{|c|}{ Average $1989-93$ withdrawals } \\
\hline Mill Street & 28 & 0.61 & 0.46 & 0.15 \\
\hline South Middleton gage & 66 & .59 & .45 & .15 \\
\hline Log Bridge Road & 73 & .56 & .42 & .14 \\
\hline Route 1 & 144 & .58 & .44 & .15 \\
\hline Ipswich gage & 178 & .57 & .43 & .14 \\
\hline Mill Road & 184 & .57 & .43 & .14 \\
\hline \multicolumn{5}{|c|}{ No withdrawals } \\
\hline Mill Street & 33 & 0.72 & 0.54 & 0.18 \\
\hline South Middleton gage & 76 & .68 & .51 & .17 \\
\hline Log Bridge Road & 89 & .68 & .51 & .17 \\
\hline Route 1 & 161 & .65 & .49 & .16 \\
\hline Ipswich gage & 200 & .64 & .48 & .16 \\
\hline Mill Road & 206 & .64 & .48 & .16 \\
\hline
\end{tabular}




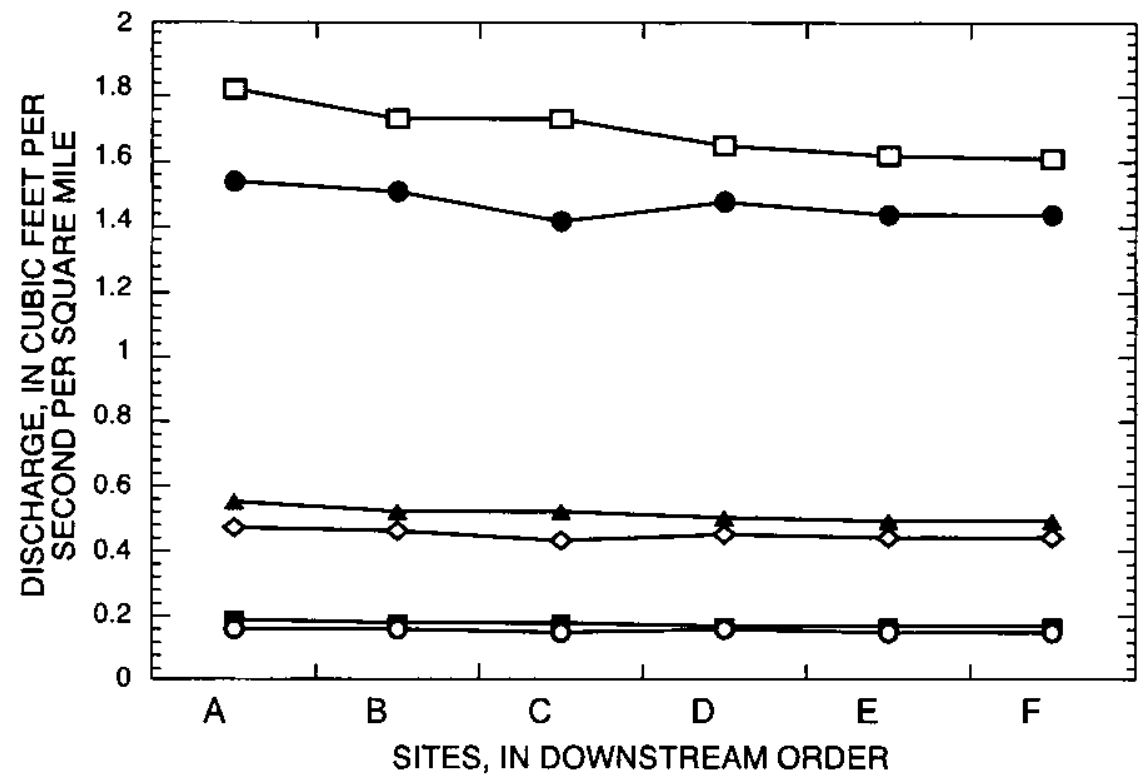

\section{EXPLANATION}

$-\square-Q_{M A}$, no withdrawals

$-Q_{M A, 1989-93}$

withdrawals

- Tennant 30-percent $Q_{M A}$, no withdrawals

$\sim$ Tennant 30-percent $Q_{M A}$, 1989-93 withdrawals

$\rightarrow$ Tennant 10-percent $Q_{M A}$,

-O- Tennant $0.1 Q_{\text {MA }}$, 1989-93 withdrawals

Figure 21. Mean annual flow (Q $Q_{M A}$ ) and streamflow requirements determined by the Tennant method for (A) Mill Street, North Reading/Reading, (B) lpswich River at South Middleton (01101500), (C) Log Bridge Road, Middleton/Danvers, $(D)$ Route 1, Topsfield, $(E)$ Ipswich River near Ipswich (01102000), and $(F)$ Mill Road, Ipswich/Hamilton, Massachusetts. (See fig. 1 for site locations.)

The 20-percent $Q_{M A}$, a value used by Tennant to represent good habitat in the winter season, averaged $0.29\left(\mathrm{ft}^{3} / \mathrm{s}\right) / \mathrm{mi}^{2}$ under average $1989-93$ withdrawals, and $0.33\left(\mathrm{ft}^{3} / \mathrm{s}\right) / \mathrm{mi}^{2}$ under no withdrawals. The 25 percent $Q_{M A}$, used to set streamflow requirements in the Canadian Atlantic Provinces (Dunbar and others, 1998), averaged $0.36\left(\mathrm{ft}^{3} / \mathrm{s}\right) / \mathrm{mi}^{2}$ under average 1989-93 withdrawals, and $0.41\left(\mathrm{ft}^{3} / \mathrm{s}\right) / \mathrm{mi}^{2}$ under no withdrawals.

\section{New England Aquatic- Base-Flow Method}

The median monthly mean flows for August, normalized for drainage area at the six sites, ranged from 0.17 to $0.19\left(\mathrm{ft}^{3} / \mathrm{s}\right) / \mathrm{mi}^{2}$ and averaged $0.18\left(\mathrm{ft}^{3} / \mathrm{s}\right) / \mathrm{mi}^{2}$ under average 1989-93 withdrawals; and ranged from 0.25 to $0.47\left(\mathrm{ft}^{3} / \mathrm{s}\right) / \mathrm{mi}^{2}$, and averaged $0.34\left(\mathrm{ft}^{3} / \mathrm{s}\right) / \mathrm{mi}^{2}$ under no withdrawals (fig. 22). The median of the monthly mean flows for August at the upstream site (Mill Street in North Reading/Reading) was very close to the USFWS ABF summer default streamflow value of $0.50\left(\mathrm{ft}^{3} / \mathrm{s}\right) / \mathrm{mi}^{2}$. The medians of the monthly mean flows for August under no withdrawals decrease from upstream to downstream, possibly because the area of sand and gravel as a percentage of drainage area at each site decreases. In addition, the percentage of wetland area, which produces larger evapotranspiration losses than the non-wetland area, increases.

\section{Wetted-Perimeter Method}

Streamflow requirements were determined by the Wetted-Perimeter method at four riffle sites on the Ipswich River (fig. 23). The Route 1 riffle, the only site surveyed that had a natural channel, had a streamflow requirement normalized for drainage area that ranged between 0.22 and $0.56\left(\mathrm{ft}^{3} / \mathrm{s}\right) / \mathrm{mi}^{2}$, depending on the degree of submersion of boulder substrate that is included as wetted perimeter. The other three sites, Mill Street in North Reading/Reading, Log Bridge Road in Middleton, and Mill Road in Ipswich/Hamilton all have highly altered channels. Flow requirements at these sites, normalized for drainage area, were $0.38,0.42$, and $0.46\left(\mathrm{ft}^{3} / \mathrm{s}\right) / \mathrm{mi}^{2}$, respectively, and averaged $0.42\left(\mathrm{ft}^{3} / \mathrm{s}\right) / \mathrm{mi}^{2}$. These streamflow requirements 


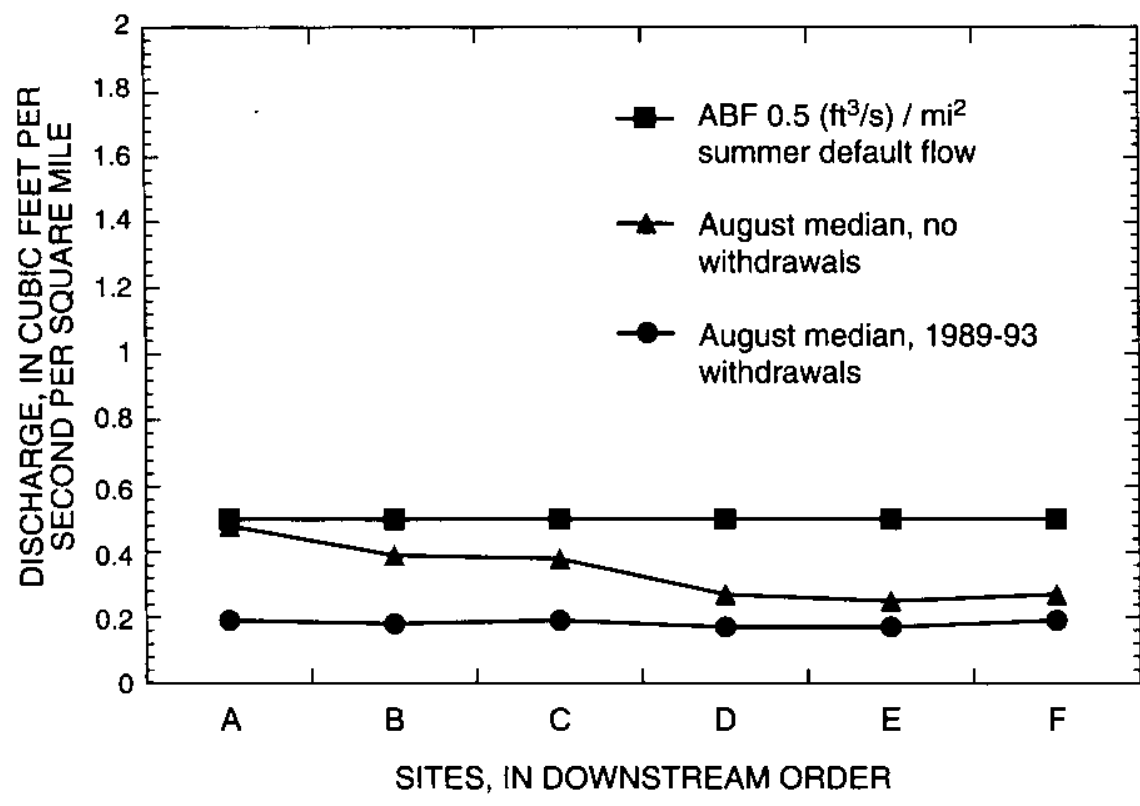

Figure 22. Streamflow requirements determined by the New England AquaticBase-Flow summer-default flow and the median of monthly mean flows for August at $(A)$ Mill Street, North Reading/Reading, $(B)$ Ipswich River at South Middleton (01101500), (C) Log Bridge Road, Middleton/Danvers, $(D)$ Route 1, Topsfield, (E) Ipswich River near Ipswich (01102000), and $(F$ Mill Road, Ipswich/Hamilton, Massachusetts. (See fig. 1 for site locations.)

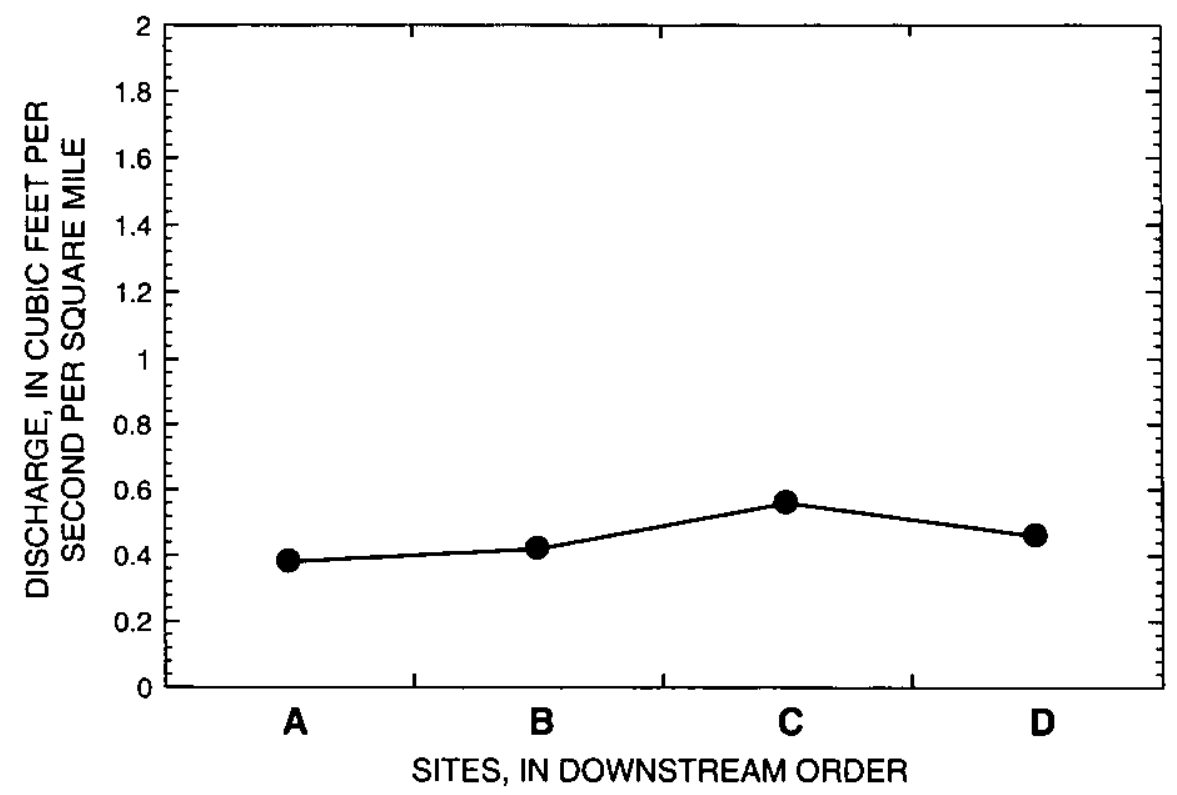

Figure 23. Streamflow requirements determined by the Wetted-Perimeter method at four riffle sites: $(A)$ Mill Street, North Reading/Reading, $(B)$ Log Bridge Road, Middleton/Danvers, (C) Route 1, Topsfield, and (D) Mill Road, Ipswich/Hamilton, Massachusetts. (See fig. 1 for site locations.) correspond to a water level that provides a fully wetted channel bed, and maintains sufficient water at riffle "choke points" to allow fish passage. Because of different shapes of the riffle cross section, however, flows estimated by this method may not necessarily provide water depths or areas of flowing water at the stream margins or within portions of the riffle that are sufficient for these areas to be suitable habitat for fish.

The Wetted-Perimeter method has a degree of subjectivity if the point of maximum curvature in the wetted-perimeter-to-discharge relation is difficult to determine. Consequently, streamflow requirements were determined from breaks in the slope of the wetted-perimeter-discharge curves that corresponded to a fully wetted channel bed. The point where the water level reaches the bottom of the stream bank was determined from the toe-of-bank elevations identified during site surveys. A variety of channel characteristics, however, affected the wettedperimeter-to-discharge relation and the determination of the stage representing a fully wetted channel bed at the four riffle reaches surveyed for this study.

\section{Mill Street, North Reading/Reading}

Three cross sections were surveyed in this altered riffle reach. The upper cross section (just downstream of the bridge face) was not used because the channel banks and the streambed are highly modified by riprap and a stone wall. Accordingly, a wetted-perimeterto-discharge relation was established at a cross section located midway down the riffle. The right 
streambank at this section also contained some riprap. For this section, breaks in the wetted-perimeter-todischarge relation correspond to a fully wetted channel bed at a discharge of about $7 \mathrm{ft}^{3} / \mathrm{s}$. At this discharge, the water depth in the deepest portion of the cross section was estimated to be about $0.4 \mathrm{ft}$.

\section{Log Bridge Road,} Middleton/Danvers

Alterations to the channel at this site have created a short riffle. Although four cross sections were surveyed, three sections were in ponded water either upstream or downstream of the riffle. Detailed crosssectional data were collected at the upstream end of the riffle along the rock pile that serves as the control. A sharp break point in the wetted-perimeter-to-discharge relation corresponds to a discharge of about $11 \mathrm{ft}^{3} / \mathrm{s}$. The water level that best represents a fully wetted channel bed, however, corresponds to a discharge of $22 \mathrm{ft}^{3} / \mathrm{s}$. At this discharge, the water depth in the narrow gaps between rocks was estimated to be about 0.7 to $1.0 \mathrm{ft}$, and water depth over the rocks was estimated to be about 0.1 to $0.2 \mathrm{ft}$. These depths would provide passage for fish that could negotiate the high water velocities through the gaps between the rocks.

\section{Route 1, Topsfield}

Three cross sections were surveyed in this natural riffle; the hydraulic control section at the upstream end of the riffle was surveyed in the most detail. The wetted-perimeter-to-discharge relation shows a distinct break in slope at about $55 \mathrm{ft}^{3} / \mathrm{s}$. At this discharge, some of the large boulders along the right side of the channel are covered, and water is beginning to move up the banks. A lower discharge of about $22 \mathrm{ft}^{3} / \mathrm{s}$ fills the low-flow channel along the left side of the river, and barely covers the streambed between the boulders on the shelf along the right side of the river. Discharges of 22 and $55 \mathrm{ft}^{3} / \mathrm{s}$ were estimated to correspond to depths of about 1.1 and $1.9 \mathrm{ft}$, respectively, in the deeper left side of the channel. Water depths at the lower discharge would provide fish passage along the left side of the channel, and may provide minimal macroinvertebrate habitat beneath the boulders along the right side of the channel; however, the right side of the channel would not provide suitable habitat for fish. Discharges between 22 and $55 \mathrm{ft}^{3} / \mathrm{s}$ do not show a distinct break in the wetted-perimeter-to-discharge relation because the large boulders in the channel gradually increase the wetted perimeter as they become submerged.

\section{Mill Road, Ipswich/Hamilton}

Three cross sections were surveyed at this historical mill site; the upstream section at the control was surveyed in the most detail. The wetted-perimeter-todischarge relation shows a break in slope at around $60 \mathrm{ft}^{3} / \mathrm{s}$, corresponding to the stage where the stream channel is fully wetted, with the exception of a small vegetated gravel bar in the left center of the channel. The presence of grass and other herbaceous vegetation on the bar indicate that it is seldom continuously submerged in summer. A discharge of $60 \mathrm{ft}^{3} / \mathrm{s}$ corresponds to a depth of about $1.3 \mathrm{ft}$ in the thalweg along the left side of the channel, which would provide sufficient depth for fish passage.

\section{R2Cross Method}

The R2Cross method (fig. 24) requires fows, normalized for drainage area at the four sites, that range from 0.38 to $1.4\left(\mathrm{ft}^{3} / \mathrm{s}\right) / \mathrm{mi}^{2}$. The Route 1 riffle, the only site surveyed with a natural channel, had a streamflow requirement normalized for drainage area of $0.42\left(\mathrm{ft}^{3} / \mathrm{s}\right) / \mathrm{mi}^{2}$. The other three sites, Mill Street in North Reading/Reading, Log Bridge Road in Middleton, and Mill Road in Ipswich/Hamilton all have highly altered channels. Flow requirements at these sites, normalized for drainage area, are 0.38 , 0.44 , and $1.39\left(\mathrm{ft}^{3} / \mathrm{s}\right) / \mathrm{mi}^{2}$, respectively, and average $0.74\left(\mathrm{ft}^{3} / \mathrm{s}\right) / \mathrm{mi}^{2}$. The large range of values may be attributed to channel alterations related to historical dam, mill and bridge construction, such as widening or narrowing of the stream channel, the addition of fill and riprap to the stream channel or banks, and other alterations.

The $\mathrm{R} 2 \mathrm{Cross}$ method physically relates discharge to specific criteria (table 6) for percentage of bankfall wetted perimeter, average velocity, and mean depth in the channel. This method, therefore, is related directly to flow conditions at riffle "choke points." 


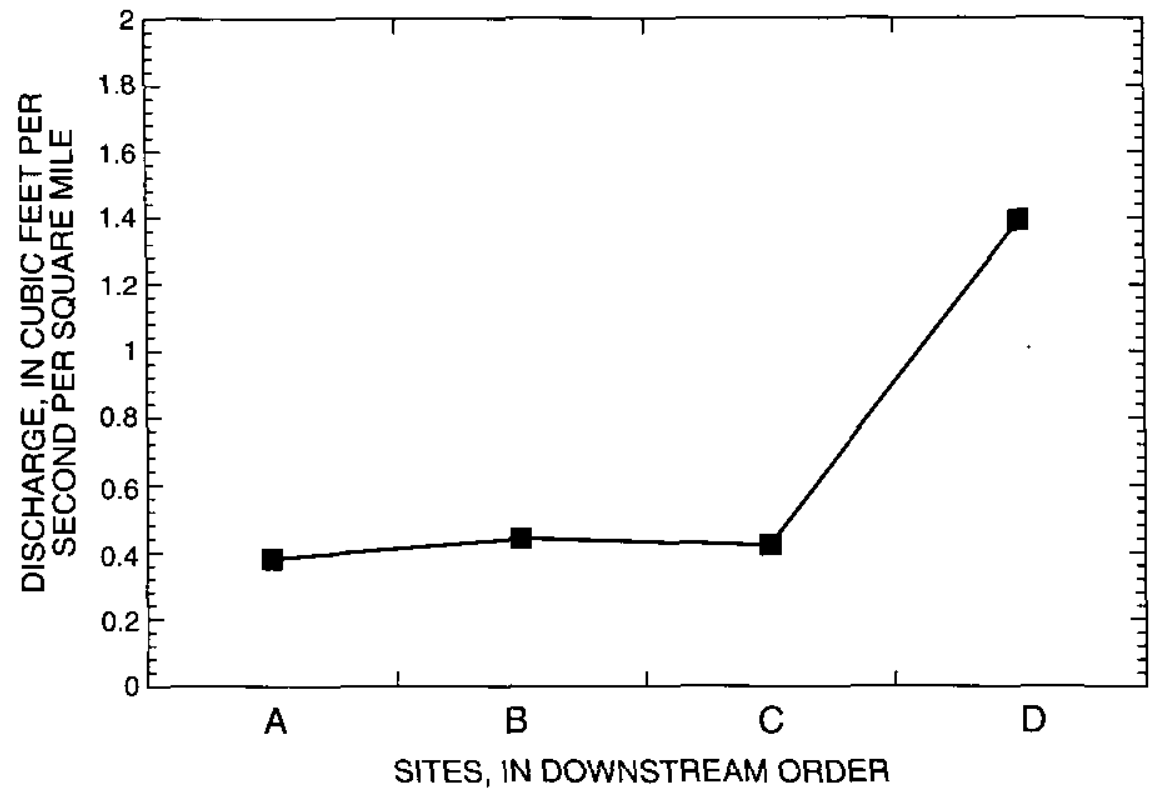

Figure 24. Streamflow requirements determined by the R2Cross method at four riffle sites: $(A)$ Mill Street, North Reading/Reading, $(B)$ Log Bridge Road,

Middleton/Danvers, (C) Route 1, Topsfield, and (D) Mill Road, Ipswich/Hamilton, Massachusetts. (See fig. 1 for site locations.)

Maintenance of streamflow requirements determined by the R2Cross method over these critical riffles would prevent the river from becoming segmented during low flows, and also would appear to provide adequate habitat in adjacent non-riffle reaches to sustain fish communities during critical summer low-flow periods.

The hydraulic criteria used in R2Cross were developed in Colorado to quantify the amount of streamflow required to preserve the environment to a reasonable degree (Espegren, 1996). To account for seasonal streamflow variability, different streamflow requirements are established for the summer and winter seasons. Streamflows in Colorado generally are lower in late summer, fall, and winter (September through March), and higher in spring and summer (April through August) because of snowmelt runoff. In Colorado, initial streamflow requirements are based upon the streamflow that meets all three hydraulic criteria in summer, and two of the three hydraulic criteria in winter. These streamflow requirements can be modified on the basis of biologic considerations, such as stream conditions, species composition, and aquatic-habitat quality (Espegren, 1996), and upon water availability (G.D. Espegren, Colorado Water Conservation Board, written commun., 2001). Similar seasonal R2Cross criteria could be adopted in Massachusetts, but the habitat quality that corresponds to streamflow requirements determined from the use of two of the three hydraulic criteria during the summer months would require further evaluation. Streamflows in coastal Massachusetts generally are lowest in late summer (July through September). Unlike mountain runoff streams in Colorado, which have low flows during winter, streams in coastal Massachusetts have additional stresses during the summer months that are linked to low streamflows, such as high stream temperatures and low dissolvedoxygen concentrations. Average R2Cross streamflow requirements, based on meeting two of the three hydraulic criteria, at the four riffle sites were $0.24\left(\mathrm{ft}^{3} / \mathrm{s}\right) / \mathrm{mi}^{2}$.

\section{The Range of Variability Approach}

Richter and others (1997) recommend use of the range of variation of a natural streamflow regime as the basis for setting management targets in the Range of Variability Approach (RVA). For this report, streamflow values used in the RVA were simulated for the 1961-95 period by use of HSPF model simulations (Zarriello and Ries, 2000) for conditions that represent no withdrawals (approximate natural flow conditions). The range of variation in monthly mean flows simulated under no withdrawals for six sites on the Ipswich River is shown in table 15. The range of variation in the annual 1-, 3-, 7-, 30-, and 90day low-flow statistics, and additional measures of low flow used by the RVA as measurement targets for the Middleton and South Ipswich gages are given in tables 16 and 17 . 
Table 15. Median, upper, and lower quartiles of monthly mean flow, simulated for four sites for the 1961 to 1995 period with the Ipswich River Basin model for nowithdrawals and 1991 land-use conditions, Ipswich River Basin, Massachusetts

[Source: Zarriello and Ries, 2000. Number in parentheses is discharge per unit drainage basin area, given in cubic foot per second per square mile. $\mathrm{f}^{3} / \mathrm{s}$, cubic foot per second]

\begin{tabular}{|c|c|c|c|c|c|c|c|c|c|c|c|c|}
\hline \multirow{2}{*}{$\begin{array}{l}\text { Percen- } \\
\text { tile }\end{array}$} & \multicolumn{12}{|c|}{ Monthly mean flow $\left(\mathrm{ft}^{3} / \mathrm{s}\right)$} \\
\hline & October & November & December & January & February & March & April & May & June & July & August & September \\
\hline \multicolumn{13}{|c|}{ Mill Street, North Reading/Reading } \\
\hline $75^{\text {th }}$ & $23.8(1.30)$ & $40.0(2.18)$ & $48.5(2.64)$ & $50.8(2.77)$ & $70.4(3.83)$ & $85.0(4.63)$ & $58.5(3.18)$ & $43.2(2.35)$ & $27.0(1.47)$ & $15.3(0.83)$ & $14.5(0.79)$ & $15.1 \quad(0.82)$ \\
\hline $50^{\text {th }}$ & $15.0(0.82)$ & $24.5(1.33)$ & $37.1(2.02)$ & $36.4(1.98)$ & $56.3(3.06)$ & $58.6(3.19)$ & $45.0(2.45)$ & $29.0(1.58)$ & $18.5(1.01)$ & $8.98(0.49)$ & $8.67(0.47)$ & $9.43(0.51)$ \\
\hline $25^{\text {th }}$ & $10.4(0.57)$ & $17.5(0.95)$ & $22.9(1.25)$ & $28.7(1.56)$ & $44.5(2.42)$ & $43.7(2.38)$ & $27.6(1.50)$ & $21.5(1.17)$ & $12.9(0.70)$ & $6.05(0.33)$ & $5.52(0.30)$ & $6.42(0.35)$ \\
\hline
\end{tabular}

\section{Log Bridge Road, Middleton/Danvers}

\begin{tabular}{|c|c|c|c|c|c|c|c|c|c|c|c|c|c|c|c|c|c|c|}
\hline $15^{\mathrm{mit}}$ & 3 & 80) & 132 & 2.54) & 41 & .71) & 190 & (3.65) & 39 & $.60)$ & 60 & $3.08)$ & $121 \quad(2.33)$ & 4) & 63) & 1.2 & $0.60)$ & 29.2 \\
\hline $50^{\text {th }}$ & & 16) & 104 & .00) & 103 & $.98)$ & 152 & $(2.92)$ & 167 & .21) & 125 & $(2.40)$ & $79.8(1$ & 9) & .39) & 19.2 & .37) & 19.2 \\
\hline & $2.2(0.43)$ & $42.5(0.82)$ & 63 & $(1.21)$ & 76. & $(1.46)$ & 121 & $(2.33)$ & 124 & (2.38) & 84.1 & $(1.62)$ & $56.7(1.09)$ & $35.9(0.69)$ & $14.2(0.27)$ & 11.1 & $(0.21)$ & 13.4 \\
\hline
\end{tabular}

\section{Route 1 Riffle, Topsfield}

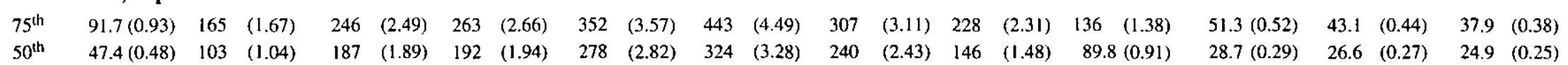

\section{Mill Road, Ipswich/Hamilton}

\begin{tabular}{|c|c|c|c|c|c|c|c|c|c|c|c|c|c|c|c|c|c|c|c|c|c|c|}
\hline & $16 \quad(0.89)$ & 10 & .6 & 17 & .45) & 38 & .61) & 42 & $3.41)$ & 71 & & 12 & 2) & 96 & 28) & 174 & & 2) & .5 & 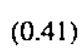 & 6.5 & \\
\hline & $(0.45)$ & 36 & 5) & 240 & 35) & 47 & 91) & 51 & 71) & 07 & 4) & 08 & 8) & 189 & 46) & 116 & & 9) & 4.8 & .27) & .8 & 5) \\
\hline & $38.7(0.30)$ & 85. & $(0.66)$ & 142 & $(1.10)$ & 184 & $(1.42)$ & 285 & $(2.20)$ & 292 & $(2.25)$ & 202 & $(1.56)$ & 132 & $(1.02)$ & 74.9 & $(0.58)$ & $28.1(0.22)$ & 19.9 & $(0.15)$ & 23.4 & $0.18)$ \\
\hline
\end{tabular}

\begin{tabular}{|c|c|c|c|c|c|c|c|c|c|c|c|c|}
\hline \multicolumn{13}{|c|}{ Average } \\
\hline $75^{\text {th }}$ & 1.03 & 1.78 & 2.52 & 2.68 & 3.59 & 4.51 & 3.09 & 2.32 & 1.40 & 0.61 & 0.54 & 0.51 \\
\hline $50^{\text {th }}$ & .58 & 1.13 & 1.94 & 1.95 & 2.86 & 3.21 & 2.41 & 1.51 & .94 & .35 & .34 & .33 \\
\hline $25^{\text {th }}$ & .39 & .76 & 1.16 & 1.46 & 2.30 & 2.34 & 1.57 & 1.07 & .64 & .25 & .20 & .24 \\
\hline
\end{tabular}


Table 16. Hydrologic data simulated for the 1961 to 1995 period for the South Middleton gage (01101500) with the Ipswich 'River Basin model for no-withdrawals and 1991 land-use conditions, Ipswich River Basin, Massachusetts

[Source: Zarriello and Ries, 2000. $\mathrm{ft}^{3} \%$ s, cubic foot per second]

\begin{tabular}{|c|c|c|c|c|c|}
\hline \multirow{2}{*}{ Period or condition } & \multicolumn{5}{|c|}{ Percentile } \\
\hline & 10th & 25th & 50 th & 75 th & 9oth \\
\hline \multicolumn{6}{|c|}{ Magnitude of monthly mean discharge $\left(\mathrm{ft}^{3} / \mathrm{s}\right)$} \\
\hline October & 15.0 & 20.0 & 28.2 & 47.7 & 72.1 \\
\hline November & 19.8 & 36.7 & 51.1 & 79.8 & 118 \\
\hline December & 34.5 & 53.6 & 88.6 & 112 & 161 \\
\hline January & 42.6 & 64.4 & 87.7 & 121 & 172 \\
\hline February & 72.0 & 104 & 130 & 162 & 223 \\
\hline March & 92.4 & 106 & 144 & 203 & 278 \\
\hline April & 56.6 & 72.8 & 108 & 138 & 260 \\
\hline May & 37.1 & 48.8 & 68.4 & 105 & 125 \\
\hline June & 19.6 & 31.0 & 44.1 & 64.5 & 141 \\
\hline July & 9.98 & 12.8 & 17.7 & 28.5 & 56.9 \\
\hline August & 6.87 & 10.3 & 17.2 & 28.2 & 40.3 \\
\hline September & 7.36 & 12.2 & 17.4 & 26.5 & 51.2 \\
\hline \multicolumn{6}{|c|}{ Magnitude and duration of annual discharge conditions $\left(\mathrm{ft}^{3} / \mathrm{s}\right)$} \\
\hline 1-day minimum & 3.30 & 3.99 & 4.89 & 6.03 & 7.15 \\
\hline 3-day minimum & 3.40 & 4.18 & 5.32 & 6.16 & 8.57 \\
\hline 7-day minimum & 3.58 & 4.59 & 6.16 & 7.11 & 8.91 \\
\hline 30-day minimum & 5.29 & 6.30 & 8.85 & 11.9 & 17.4 \\
\hline 90-day minimum & 9.43 & 11.4 & 16.4 & 22.1 & 29.3 \\
\hline 1-day maximum & 183 & 243 & 346 & 521 & 783 \\
\hline 3-day maximum & 173 & 218 & 310 & 485 & 693 \\
\hline 7-day maximum & 153 & 193 & 265 & 429 & 544 \\
\hline 30-day maximum & 119 & 147 & 198 & 281 & 340 \\
\hline 90-day maximum & 88.8 & 108 & 149 & 190 & 216 \\
\hline $\begin{array}{l}\text { 7-day minimum/mean annual } \\
\text { discharge }\end{array}$ & .05 & .06 & .08 & .10 & .14 \\
\hline
\end{tabular}


Table 16. Hydrologic data simulated for the 1961 to 1995 period for the South Middleton gage (01101500) with the Ipswich River Basin model for no-withdrawals and 1991 land-use conditions, Ipswich River Basin, Massachusetts-Continued

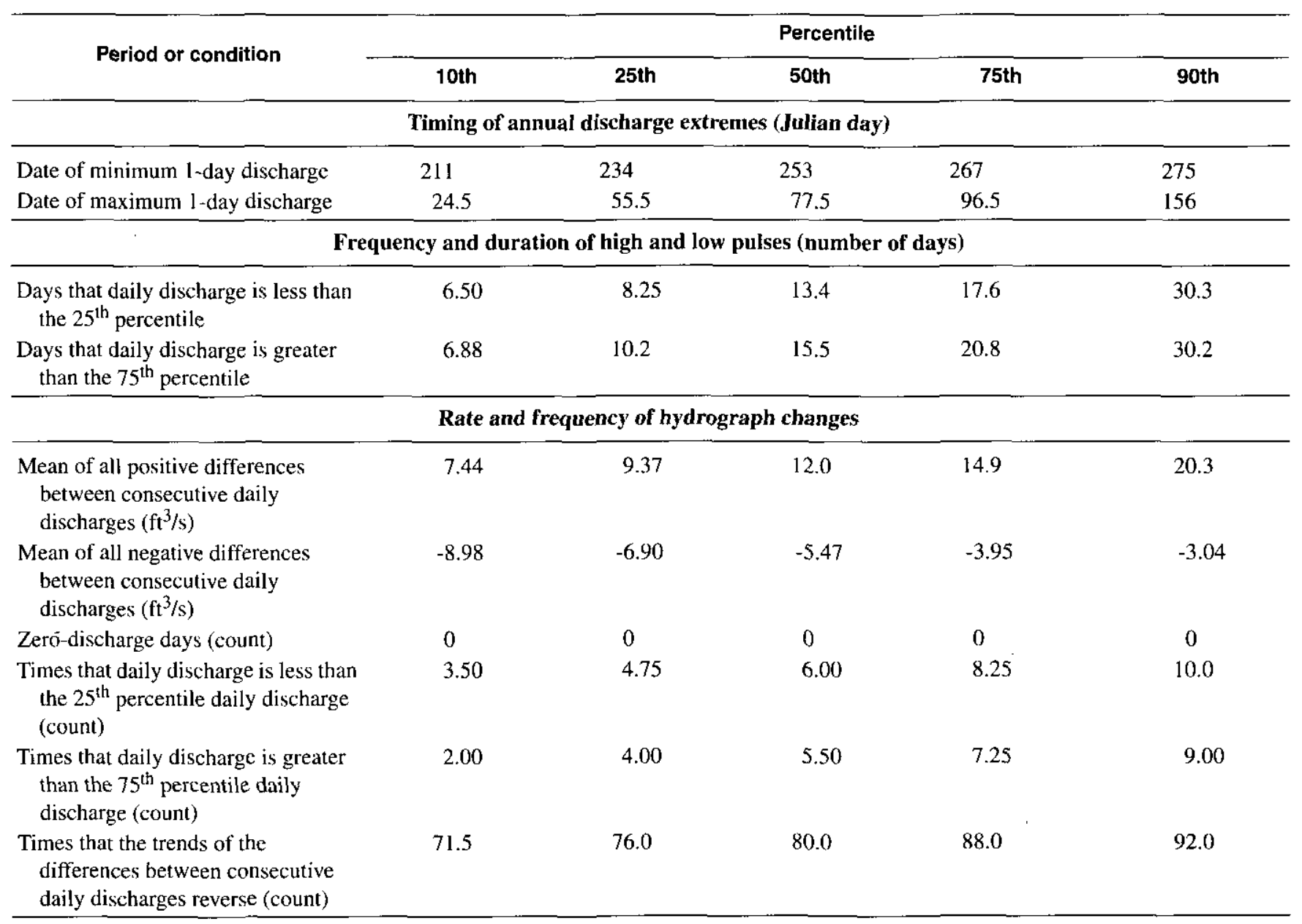


Table 17. Hydrologic data simulated for the 1961 to 1995 period for the Ipswich gage (01102000) with the model for nowithdrawals and 1991 land-use conditions, Ipswich River Basin, Massachusetts

[Source: Zarriello and Ries, $2000 . \mathrm{ft}^{3} / \mathrm{s}$, cubic foot per second]

\begin{tabular}{|c|c|c|c|c|c|}
\hline \multirow{2}{*}{ Period or condition } & \multicolumn{5}{|c|}{ Percentile } \\
\hline & 10th & 25th & 50th & 75th & 90th \\
\hline \multicolumn{6}{|c|}{ Magnitude of monthly mean discharge $\left(\mathrm{ft}^{3} / \mathrm{s}\right)$} \\
\hline October & 25.8 & 36.5 & 56.0 & 112 & 180 \\
\hline November & 47.6 & 83.1 & 133 & 205 & 309 \\
\hline December & 92.0 & 138 & 234 & 310 & 441 \\
\hline January & 110 & 180 & 241 & 328 & 472 \\
\hline February & 197 & 278 & 341 & 431 & 602 \\
\hline March & 253 & 284 & 397 & 551 & 749 \\
\hline April & 145 & 194 & 298 & 381 & 729 \\
\hline May & 95.6 & 126 & 182 & 288 & 346 \\
\hline June & 43.0 & 70.4 & 109 & 168 & 381 \\
\hline July & 18.3 & 24.5 & 34.1 & 62.5 & 135 \\
\hline August & 12.2 & 17.2 & 31.2 & 49.7 & 81.9 \\
\hline September & 13.4 & 21.3 & 28.6 & 42.9 & 106 \\
\hline \multicolumn{6}{|c|}{ Magnitude and duration of annual discharge conditions $\left(\mathrm{ft}^{3} / \mathrm{s}\right)$} \\
\hline 1-day minimum & 7.14 & 8.88 & 11.4 & 13.3 & 15.7 \\
\hline 3-day minimum & 7.24 & 9.03 & 11.6 & 13.7 & 17.9 \\
\hline 7-day minimum & 7.77 & 9.48 & 12.7 & 14.7 & 18.4 \\
\hline 30-day minimum & 9.82 & 11.9 & 17.0 & 20.6 & 34.1 \\
\hline 90-day minimum & 16.4 & 19.0 & 31.1 & 40.7 & 58.2 \\
\hline 1-day maximum & 486 & 624 & 930 & 1,340 & 1,940 \\
\hline 3-day maximum & 470 & 585 & 834 & 1,280 & 1,820 \\
\hline 7-day maximum & 424 & 527 & 714 & 1,130 & 1,470 \\
\hline 30-day maximum & 322 & 404 & 520 & 759 & 927 \\
\hline 90-day maximum & 234 & 296 & 400 & 518 & 591 \\
\hline $\begin{array}{l}\text { 7-day minimum/mean annual } \\
\text { discharge }\end{array}$ & .04 & .05 & .06 & .08 & .11 \\
\hline
\end{tabular}


Table 17. Hydrologic data simulated for the 1961 to 1995 period for the Ipswich gage (01102000) with the model for nowithdrawals and 1991 land-use conditions, Ipswich River Basin, Massachusetts-Continued

\begin{tabular}{|c|c|c|c|c|c|}
\hline \multirow{2}{*}{ Period or condition } & \multicolumn{5}{|c|}{ Percentile } \\
\hline & 10th & 25th & 50th & 75th & 90th \\
\hline \multicolumn{6}{|c|}{ Timing of annual discharge extremes (Julian day) } \\
\hline Date of minimum 1-day discharge & 207 & 238 & 256 & 270 & 276 \\
\hline Date of maximum 1-day discharge & 19.0 & 57.0 & 81.0 & 94.5 & 152.0 \\
\hline \multicolumn{6}{|c|}{ Frequency and duration of high and low pulses (number of days) } \\
\hline $\begin{array}{l}\text { Days that daily discharge is less than } \\
\text { the } 25^{\text {th }} \text { percentile }\end{array}$ & 11.1 & 15.5 & 21.3 & 26.8 & 48.8 \\
\hline $\begin{array}{l}\text { Days that daily discharge is greater } \\
\text { than the } 75^{\text {th }} \text { percentile }\end{array}$ & 6.57 & 10.9 & 15.5 & 20.6 & 31.2 \\
\hline \multicolumn{6}{|c|}{ Rate and frequency of hydrograph changes } \\
\hline $\begin{array}{l}\text { Mean of all positive differences } \\
\text { between consecutive daily } \\
\text { discharges }\left(\mathrm{ft}^{3} / \mathrm{s}\right)\end{array}$ & 14.1 & 20.3 & 27.6 & 37.2 & 46.8 \\
\hline $\begin{array}{l}\text { Mean of all negative differences } \\
\text { between consecutive daily } \\
\text { discharges }\left(\mathrm{ft}^{3} / \mathrm{s}\right)\end{array}$ & -22.9 & -16.9 & -13.0 & -9.84 & -6.63 \\
\hline Zero-discharge days (count) & 0 & 0 & 0 & 0 & 0 \\
\hline $\begin{array}{l}\text { Times that daily discharge is less than } \\
\text { the } 25^{\text {th }} \text { percentile daily discharge } \\
\text { (count) }\end{array}$ & 2.00 & 3.00 & 4.00 & 5.00 & 6.50 \\
\hline $\begin{array}{l}\text { Times that daily discharge is greater } \\
\text { than the } 75^{\text {th }} \text { percentile daily } \\
\text { discharge (count) }\end{array}$ & 2.50 & 4.00 & 5.50 & 7.00 & 9.00 \\
\hline $\begin{array}{l}\text { Times that the trends of the } \\
\text { differences between consecutive } \\
\text { daily discharges reverse (count) }\end{array}$ & 63.5 & 68.0 & 72.0 & 78.2 & 83.0 \\
\hline
\end{tabular}


In contrast to standard-setting methods, which identify minimum flows for habitat protection for seasonal time periods, the RVA recommends a range of streamflows for each month, for n-day low-flow periods, and other flow statistics. Because they are applied to shorter time periods, the streamflows at the lower limits of the target ranges, such as the 25th percentiles of monthly mean flow, tend to be substantially lower than the values determined by standard-setting methods for the summer season. For example, for streamflows simulated with no withdrawals for the four riffle study sites and two gaged sites, the average 25th-, 50th-, and 75th-percentiles of the monthly mean flows for August are 0.20, 0.34, and $0.54\left(\mathrm{ft}^{3} / \mathrm{s}\right) / \mathrm{mi}^{2}$, respectively. For three sites in the headwaters of the Ipswich River, the 25th-, 50th-, and 75th-percentiles of the monthly mean flows for August simulated under no withdrawals are: $0.30,0.47$, and $0.79\left(\mathrm{ft}^{3} / \mathrm{s}\right) / \mathrm{mi}^{2}$ for the Mill Street site in North Reading/Reading; 0.23, $0.39,0.63\left(\mathrm{ft}^{3} / \mathrm{s}\right) / \mathrm{mi}^{2}$ for the South Middleton gage in Middleton/Peabody; and 0.21, 0.37, and $0.60\left(\mathrm{ft}^{3} / \mathrm{s}\right) / \mathrm{mi}^{2}$ for Log Bridge Road, Middleton/Danvers.

Although the streamflow values represented by the 25 th percentile of the monthly mean flow at these sites are lower than the minimum streamflow requirements determined by the other standard-setting methods used in this report, the RVA restricts the magnitude, timing, frequency, and duration of these low flows by requiring streamflow to be within the 25 th to 75th percentile range for other annual low-flow statistics and measures of low flow (tables 16 and 17). For example, at the South Middleton streamgaging station, the RVA would require maintaining the 7-day annual low-flow statistic to a flow between 4.6 and $7.1 \mathrm{ft}^{3} / \mathrm{s}$, or 0.10 to $0.16\left(\mathrm{ft}^{3} / \mathrm{s}\right) / \mathrm{mi}^{2}$. The RVA also would require maintaining flows so that the daily discharge would be below the 25 th percentile of daily flows only between 8 to 17 days for the year. For the Ipswich streamgaging station, the RVA would require maintaining the 7-day annual low-flow statistic to a flow between 9.5 and $15 \mathrm{ft}^{3} / \mathrm{s}$ or 0.08 to $0.12\left(\mathrm{ft}^{3} / \mathrm{s}\right) / \mathrm{mi}^{2}$. The RVA would require maintaining flows so that the daily discharge would be below the 25 th percentile of daily flows only between 15 to 27 days for the year. Streamflows, therefore, could not be maintained continuously at or near the low levels represented by the 25 th percentile of the monthly mean flows for substantial lengths of time without exceeding the RVA limits for the other low-flow statistics for the year.

\section{Flow Statistics}

Flow-duration curves were developed from long-term simulations (1961-95) of daily flows with the HSPF model for six sites on the Ipswich River. The flow-duration curves show significant differences in the 70-, 80-, and 90-percent-exceedence flows between current conditions and the no-withdrawals scenarios (fig. 25). The flow-duration curves for the simulation under no withdrawals departs appreciably from the curves for simulations with average 1989-93 withdrawals above the 50-percent exceedence interval. The flow durations also show that the Ipswich River would not go dry at Mill Street, were there no withdrawals. 


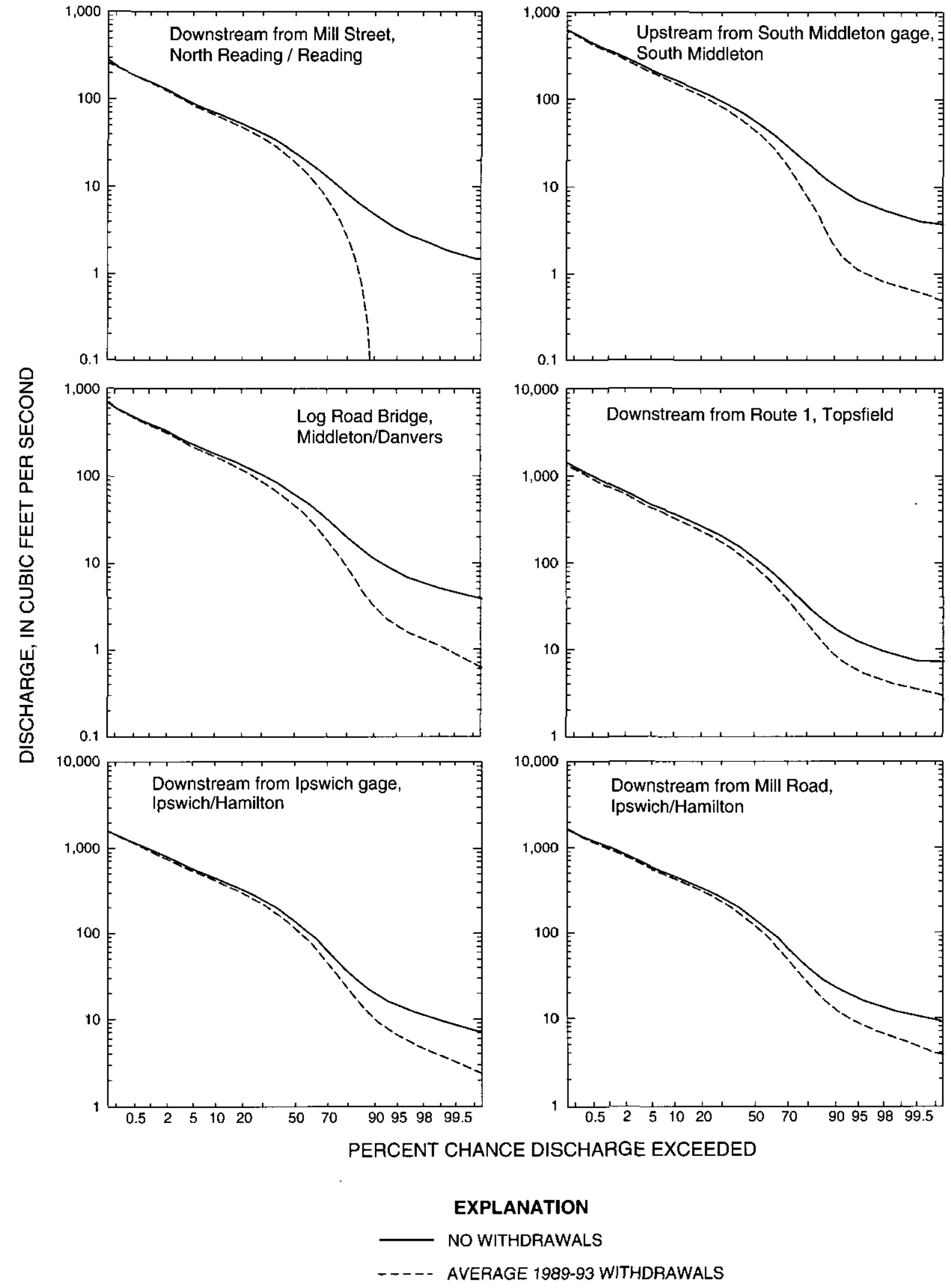

Figure 25. Flow-duration curves for six sites on the Ipswich River, Massachusetts (Zarriello and Ries, 2000). (See fig. 1 for site locations.) 
Other commonly calculated streamflow statistics that are used to establish streamflow requirements were determined at the six sites from HSPF simulations under both no withdrawals and average 1989-93 withdrawals. Comparison of the 70-, 80-, and 90-percent-exceedence flows for the simulation under no withdrawals and for the simulation under average 1989-93 withdrawals demonstrate the effects on streamflows of withdrawals for public-water supply. At a 70-percent-exceedence level, flows ranged from 0.36 to $0.39\left(\mathrm{ft}^{3} / \mathrm{s}\right) / \mathrm{mi}^{2}$ and averaged $0.38\left(\mathrm{ft}^{3} / \mathrm{s}\right) / \mathrm{mi}^{2}$ for the simulations with average 1989-93 withdrawals, and ranged from 0.5 to $0.7\left(\mathrm{ft}^{3} / \mathrm{s}\right) / \mathrm{mi}^{2}$ and averaged $0.59\left(\mathrm{ft}^{3} / \mathrm{s}\right) / \mathrm{mi}^{2}$ for the simulations under no withdrawals. At an 80-percent-exceedence level, flows ranged from 0.15 to $0.20\left(\mathrm{ft}^{3} / \mathrm{s}\right) / \mathrm{mi}^{2}$ and averaged $0.18\left(\mathrm{ft}^{3} / \mathrm{s}\right) / \mathrm{mi}^{2}$ for the simulations with average 1989-93 withdrawals, and ranged from 0.29 to $0.47\left(\mathrm{ft}^{3} / \mathrm{s}\right) / \mathrm{mi}^{2}$ and averaged $0.37\left(\mathrm{ft}^{3} / \mathrm{s}\right) / \mathrm{mi}^{2}$ for the simulations with no withdrawals. At a 90 -percentexceedence level, flows ranged from 0.05 to $0.10\left(\mathrm{ft}^{3} / \mathrm{s}\right) / \mathrm{mi}^{2}$ and averaged $0.06\left(\mathrm{ft}^{3} / \mathrm{s}\right) / \mathrm{mi}^{2}$ for the simulations with average $1989-93$ withdrawals, and ranged from 0.16 to $0.27\left(\mathrm{ft}^{3} / \mathrm{s}\right) / \mathrm{mi}^{2}$ and averaged $0.21\left(\mathrm{ft}^{3} / \mathrm{s}\right) / \mathrm{mi}^{2}$ for the simulations under no withdrawals.

The 7-day, 10-year, low-flow statistic $\left(7 Q_{10}\right)$ represents the probable minimum flow over a 7-day period that will occur on average once in 10 years. Zarriello and Ries (2000) reported that for 1991 landuse conditions, the $7 \mathrm{Q}_{10}$ flows for the South Middleton gage determined with simulated average 1989-93 withdrawals and no withdrawals are 0.012 and $0.092\left(\mathrm{ft}^{3} / \mathrm{s}\right) / \mathrm{mi}^{2}$, respectively. The $7 \mathrm{Q}_{10}$ flows for the Ipswich gage determined with simulated average 1989-93 withdrawals and no withdrawals are 0.022 and $0.066\left(\mathrm{ft}^{3} / \mathrm{s}\right) / \mathrm{mi}^{2}$, respectively. These values represent extremely low flows, even without withdrawals, and generally are an order of magnitude lower than the streamflow requirements for habitat protection identified by the other instream flow methods.

\section{COMPARISON OF STREAMFLOW REQUIREMENTS AND METHODS}

Streamflow requirements, computed by standard methods for determining a minimum flow for habitat protection and normalized for drainage area, ranged from 0.74 to $0.17\left(\mathrm{ft}^{3} / \mathrm{s}\right) / \mathrm{mi}^{2}$ (table 18 ). Methods that produced the most protective streamflows included
Table 18. Average streamflow requirements for six sites on the Ipswich River, Massachusetts

[ABF, Aquatic Base Flow; QMA: average annual daily discharge. $\left(\mathrm{ft}^{3} / \mathrm{s}\right) / \mathrm{mi}^{2}$, cubic foot per second per square mile]

\begin{tabular}{|c|c|}
\hline $\begin{array}{c}\text { Discharge } \\
\text { per unit } \\
\text { drainage } \\
\text { basin area } \\
\left(\left(\mathrm{ft}^{3} / \mathrm{s}\right) / \mathbf{m i}^{2}\right)\end{array}$ & Method \\
\hline 0.74 & R2Cross, for altered riffle sites. ${ }^{1}$ \\
\hline .67 & $\begin{array}{l}\text { Tennant } 40 \text {-percent QMA: to provide a good } \\
\text { summer habitat condition. }{ }^{2}\end{array}$ \\
\hline .59 & 70 -percent exceedence flow. ${ }^{2}$ \\
\hline .56 & Wetted-Perimeter flow, for natural riffle site. ${ }^{3}$ \\
\hline .54 & $75^{\text {th }}$ percentile of monthly-mean flow for August. ${ }^{2}$ \\
\hline .50 & ABF default summer flow. ${ }^{2}$ \\
\hline .50 & $\begin{array}{l}\text { Tennant } 30 \text {-percent } \mathrm{Q}_{\mathrm{MA}} \text {, to provide a fair summer } \\
\text { habitat condition. }{ }^{2}\end{array}$ \\
\hline .42 & R2CROSS, for natural riffle site ${ }^{3}$ \\
\hline .41 & Wetted-Perimeter flow, for altered riffle sites. ${ }^{\prime}$ \\
\hline .41 & Canadian Atlantic Provinces 25-percent $\mathrm{QMA}_{\mathrm{MA}}$ \\
\hline .37 & 80 -percent-exceedence flow. ${ }^{2}$ \\
\hline .34 & $\begin{array}{l}50^{\text {th }} \text { percentile (median) of monthly-mean flow for } \\
\text { August. }\end{array}$ \\
\hline .21 & 90 -percent-exceedence flow. ${ }^{2}$ \\
\hline .20 & $25^{\text {th }}$ percentile of monthly-mean flow for August. ${ }^{2}$ \\
\hline .18 & Median 30-day low-flow. ${ }^{2}$ \\
\hline .17 & $\begin{array}{l}\text { Tennant 10-percent } Q_{M A} \text {, to provide a poor } \\
\text { summer habitat condition. }{ }^{2}\end{array}$ \\
\hline .11 & Median 7-day low flow. ${ }^{2}$ \\
\hline .08 & 7-day, 10 -year low flow $\left(7 \mathrm{Q}_{10}\right) .^{4}$ \\
\hline
\end{tabular}

R2Cross, which averaged $0.74\left(\mathrm{ft}^{3} / \mathrm{s}\right) / \mathrm{mi}^{2}$ at three altered riffle sites, and the Tennant 40-percent QMA method [considered by Tennant (1976) to provide a good summer habitat condition], which averaged $0.67\left(\mathrm{ft}^{3} / \mathrm{s}\right) / \mathrm{mi}^{2}$. Methods that produced a slightly lower minimum flow requirement include the 70 percent flow exceedence statistic calculated from simulated flows under no withdrawals, which averaged $0.59\left(\mathrm{ft}^{3} / \mathrm{s}\right) / \mathrm{mi}^{2}$; the Wetted-Perimeter method, which required $0.56\left(\mathrm{ft}^{3} / \mathrm{s}\right) / \mathrm{mi}^{2}$ to submerge a cobble-andboulder streambed at the one natural-riffle study site; and the Tennant 30-percent QMA, (considered by Tennant to provide a fair summer habitat condition), which averaged $0.50\left(\mathrm{ft}^{3} / \mathrm{s}\right) / \mathrm{mi}^{2}$, the same value as the 
New England ABF default-flow value for the summer season. The R2Cross method for the one natural riffle study site, the Wetted-Perimeter method for the three altered riffle sites, and the Canadian Atlantic Provinces 25-percent $Q_{M A}$ yielded similar results, averaging $0.42,0.41$, and $0.41\left(\mathrm{ft}^{3} / \mathrm{s}\right) / \mathrm{mi}^{2}$, respectively. Slightly lower streamflow requirements were determined by the 80-percent-flow-exceedence statistic and the median of the monthly mean flow for August, both of which were calculated on the basis of the HSPF simulations for no withdrawals, and which averaged 0.37 and $0.34\left(\mathrm{ft}^{3} / \mathrm{s}\right) / \mathrm{mi}^{2}$, respectively. Methods that produced the least conservative flow requirements include the 90 percent flow-exceedence statistic, (calculated from simulated flows under no withdrawals), which averaged $0.21\left(\mathrm{ft}^{3} / \mathrm{s}\right) / \mathrm{mi}^{2}$; the Tennant 10-percent QMA, (considered by Tennant to provide a poor or severely degraded summer habitat condition), which averaged $0.17\left(\mathrm{ft}^{3} / \mathrm{s}\right) / \mathrm{mi}^{2}$, and the $7 \mathrm{Q}_{10}$ statistic, which averaged only $0.08\left(\mathrm{ft}^{3} / \mathrm{s}\right) / \mathrm{mi}^{2}$ for the South Middleton and Ipswich gages.

Minimum streamflow values for the four riffle study sites were determined by the Tennant 30 -percent QMA, median of monthly mean flows for August (calculated from simulated flows under no withdrawals), Wetted-Perimeter, and R2Cross methods (table 19). For the four riffle study sites, average minimum streamflows for habitat protection, determined by averaging the values from the four methods and normalized for drainage area were $0.45\left(\mathrm{ft}^{3} / \mathrm{s}\right) / \mathrm{mi}^{2}$ for Mill St.,
North Reading/Reading; $0.44\left(\mathrm{ft}^{3} / \mathrm{s}\right) / \mathrm{mi}^{2}$ for Log Bridge Road, Middleton/Danvers; $0.44\left(\mathrm{ft}^{3} / \mathrm{s}\right) / \mathrm{mi}^{2}$ for Route 1, Topsfield; and $0.65\left(\mathrm{ft}^{3} / \mathrm{s}\right) / \mathrm{mi}^{2}$ for Mill Road, Ipswich/Hamilton. A single minimum streamflow value, determined by averaging the values determined by the four methods at each of the four study sites, is $0.49\left(\mathrm{ft}^{3} / \mathrm{s}\right) / \mathrm{mi}^{2}$. This value is similar to the ABF summer default value of $0.5\left(\mathrm{ft}^{3} / \mathrm{s}\right) / \mathrm{mi}^{2}$. Minimum streamflows, normalized for drainage area, were also determined for the two gaged sites on the Ipswich River by use of the Tennant 30-percent QMA method and the ABF median of monthly mean flow for August method. The values determined by these two methods were 0.51 and $0.39\left(\mathrm{ft}^{3} / \mathrm{s}\right) / \mathrm{mi}^{2}$ for the South Middleton gage, and 0.48 and $0.25\left(\mathrm{ft}^{3} / \mathrm{s}\right) / \mathrm{mi}^{2}$ for the Ipswich gage, respectively. If these streamflow values were averaged with the values from the four riffle study sites, the overall minimum streamflow value would be unchanged.

Three of the four riffle study sites have altered channels. Only one study site, the riffle near Route 1 in Topsfield, has a natural, unaltered channel. Minimum streamflows determined by use of Wetted-Perimeter and R2Cross methods could change if the altered sites were restored. Streamflows determined by use of R2Cross, which are designed to provide the depth, velocity, and wetted perimeter needed for habitat in riffles, would be particularly sensitive to channel alterations. Consequently, a reasonable minimum

Table 19: Streamflow requirements computed by Tennant, Aquatic-Base-Flow (median of monthly mean flow for August), Wetted-Perimeter, and R2Cross methods for four riffle study sites, Ipswich River, Massachusetts

[Unbiased standard deviation: $s\left(c_{n}\right)$, where $c_{n}=1.08540$ for $n=4$. Unbiased coefficient of variation: Sokal and Rohlf, 1995. (1+1/4n)V. ABF, Aquatic Base Flow; QMA, mean annual flow; WP, wetted perimeter. --, not applicable. $\left(\mathrm{ft}^{3} / \mathrm{s}\right) / \mathrm{mi}^{2}$, cubic foot per second per square mile]

\begin{tabular}{|c|c|c|c|c|c|c|c|c|c|}
\hline \multirow{3}{*}{ Method } & \multicolumn{5}{|c|}{$\begin{array}{l}\text { Streamflow requirement } \\
\qquad\left(\mathrm{ft}^{3} / \mathrm{s}\right) / \mathrm{mi}^{2}\end{array}$} & \multirow{3}{*}{$\begin{array}{l}\text { Standard } \\
\text { deviation }\end{array}$} & \multirow{3}{*}{$\begin{array}{l}\text { Unbiased } \\
\text { standard } \\
\text { deviation }\end{array}$} & \multirow{3}{*}{$\begin{array}{l}\text { Coefficient } \\
\text { of variation }\end{array}$} & \multirow{3}{*}{$\begin{array}{l}\text { Unbiased } \\
\text { coefficient } \\
\text { of variatior }\end{array}$} \\
\hline & \multicolumn{2}{|c|}{ Altered channel } & \multirow{2}{*}{$\begin{array}{c}\begin{array}{c}\text { Natural } \\
\text { channel }\end{array} \\
\text { Route 1, } \\
\text { Topsfield }\end{array}$} & \multirow{2}{*}{$\begin{array}{c}\begin{array}{c}\text { Altered } \\
\text { channel }\end{array} \\
\text { Mill Road, } \\
\text { Ipswich/ } \\
\text { Hamilton }\end{array}$} & \multirow[b]{2}{*}{ Mean } & & & & \\
\hline & $\begin{array}{l}\text { Mill Street, } \\
\text { North } \\
\text { Reading/ } \\
\text { Reading }\end{array}$ & $\begin{array}{l}\text { Log Bridge } \\
\text { Road, } \\
\text { Middleton/ } \\
\text { Danvers }\end{array}$ & & & & & & & \\
\hline \multicolumn{10}{|l|}{ Tennant } \\
\hline$\left(0.3 \mathrm{Q}_{\mathrm{MA}}\right) \ldots$. & 0.54 & 0.51 & 0.49 & 0.48 & 0.51 & 0.026 & 0.029 & 5.24 & 5.6 \\
\hline ABF & .48 & .38 & .27 & .27 & .35 & .101 & .110 & 28.9 & 30.7 \\
\hline WP & .38 & .42 & .56 & .46 & .46 & .077 & .084 & 17.0 & 18.0 \\
\hline R2Cross ............. & .38 & .44 & .42 & 1.39 & .66 & .489 & .531 & 74.4 & 79.0 \\
\hline
\end{tabular}


streamflow for habitat protection in the Ipswich River in summer also can be estimated by averaging the minimum streamflow values for four sites determined by the Tennant 30-percent QMA $\left[0.51\left(\mathrm{ft}^{3} / \mathrm{s}\right) / \mathrm{mi}^{2}\right]$; the median of monthly mean flows for August for the simulated 1961-95 period under no withdrawals, $\left[0.35\left(\mathrm{ft}^{3} / \mathrm{s}\right) / \mathrm{mi}^{2}\right]$; the wetted-perimeter value for the three altered riffle sites $\left[0.42\left(\mathrm{ft}^{3} / \mathrm{s}\right) / \mathrm{mi}^{2}\right]$, and the $\mathrm{R} 2$ Cross value required to maintain a reasonable flow at the natural riffle site near Route $1\left[0.42\left(\mathrm{ft}^{3} / \mathrm{s}\right) / \mathrm{mi}^{2}\right]$. The mean streamflow obtained from these four methods is $0.42\left(\mathrm{ft}^{3} / \mathrm{s}\right) / \mathrm{mi}^{2}$. This streamflow is a reasonable target for habitat protection because each of the four methods takes into account slightly different aspects of hydrological conditions. Maintenance of this flow would prevent the river from becoming segmented at the three altered riffle sites, and would maintain sufficient depth, velocity, and wetted perimeter for habitat protection at the Route 1 natural riffle site. Under simulated "natural" flow conditions (HSPF model simulations without withdrawals), this flow has an exceedence probability of about 77 percent.

Many of the advantages and disadvantages of the different methods depend on assumptions inherent within the methods. For example, methods that are based on a flow statistic such as the ABF, Tennant, and RVA cannot be applied to ungaged sites without extrapolation from an existing gage, or synthesis of a hydrologic record from a watershed model, or a regional regression equation that relates flow to basin characteristics. Furthermore, application of these methods to sites that are affected by human influences (for example, withdrawals) may not identify streamflows that are appropriate for habitat protection. A major advantage of these methods is that they can be applied readily if the long-term unregulated flow information is available. The ABF median of monthly mean flows for August method is very sensitive to regulation because the magnitude of streamflow depletion caused by summer ground-water withdrawals is a large percentage of August streamflow. The magnitude of streamflow depletion caused by ground-water and surfacewater withdrawals also can have significant effects upon the annual 1-, 3-, 7-, 30-, and 90-day low-flow statistics and the monthly flow statistics used by the RVA. In contrast, the Tennant method is less sensitive to regulation because its value is a percentage of a mean annual flow statistic that is heavily weighted to high flows that are least affected by regulation. The difference between streamflow requirements determined at the Ipswich study sites from HSPF simulations (Zarriello and Ries, 2000) under no-withdrawals conditions and average 1989-93 withdrawals illustrate the effects of regulation on streamflow and the importance of having simulated "naturalized flows" for determining streamflow requirements for habitat protection. For the Tennant and ABF methods, the differences between the streamflow requirements determined under average 1989-93 withdrawals and no withdrawals, average about 12 and 47 percent, respectively.

The Tennant, ABF, Wetted-Perimeter, and R2Cross methods each identified different minimum streamflows for the four riffle study sites. Coefficientof-variation values were calculated to compare the relative amounts of variation in the mean streamflow requirements determined by each method (table 19). The Tennant method is the least sensitive to basin characteristics that affect seasonal variability because its value is derived from the mean annual flow statistic, which is largely a function of drainage area (Ries and Friesz, 2000). Consequently, the streamflow requirements identified by the Tennant method, normalized for drainage area, exhibit little difference among sites. The coefficient of variation for the streamflow requirement, normalized to drainage area, determined by the Tennant method, was 5.6 percent.

The median of monthly mean flow for August under no withdrawals does not provide the same value for the four riffle study sites with respect to drainage area. The coefficient of variation for the median of monthly mean flow for August, normalized for drainage area, was 30.7 percent. Differences in the streamflow requirements among study sites may reflect differences in basin characteristics. Upstream sites have a greater percentage of sand and gravel deposits (65-70 percent in the headwaters and about $40-45$ percent in the lower basin). Areas with a greater percentage of sand and gravel aquifers are able to sustain higher low flows. Differences in the area and distribution of wetlands also affect the magnitude and variability of low flows. Wetlands generally transpire more than non-wetland areas because of the availability of water. The sites above the South Middleton streamgaging station have less wetland area than the sites downstream; therefore, evapotranspiration loss is less above the South Middleton streamgaging station than below it. Because of the differences in basin characteristics among sites, the upper and lower quartile and median of the August flow at the upstream sites are 
higher than those at downstream sites. Consequently, the ABF-recommended $0.5\left(\mathrm{ft}^{3} / \mathrm{s}\right) / \mathrm{mi}^{2}$ summer default streamflow seldom may be obtainable during summer for some downstream locations in the Ipswich River, even if all withdrawals were stopped.

An advantage of the Wetted-Perimeter and R2Cross methods is that they are based upon field observations that are independent of actual flow conditions, so the values obtained by these methods can be applied in hydrologically disturbed drainage basins and at ungaged sites. A disadvantage of these methods is that differences in channel geometry among riffle sites create variability in the resulting streamflow requirements. The coefficients of variation for the streamflow requirements, normalized for drainage area, determined by the Wetted-Perimeter and R2Cross methods for the four riffle sites were 18.0 and 79.0 percent, respectively. Differences in stream gradient and roughness characteristics at riffle sites increase the variability of $\mathrm{R} 2$ Cross streamflow requirements because of the effect these characteristics have upon the hydraulic parameters (mean depth, mean velocity, and percentage of bankfull wetted perimeter) used as criteria to determine streamflow requirements by the R2Cross method. Time and resources and the scarcity of suitable, unaltered riffles limited the number of riffles surveyed during this study; a greater sample size would have provided more robust estimates of the mean streamflow requirements.

The critical riffle sites where the WettedPerimeter and R2Cross methods are best applied can be difficult to identify. Three of the four riffle study sites on the Ipswich River have altered channels. Alterations to channels can have a direct effect on the streamflow requirements determined with the WettedPerimeter and R2Cross methods. The reinforcement of streambanks and streambeds with riprap prevents natural width and depth adjustments. The artificial widening or narrowing of stream channels can affect wetted perimeter, mean velocity, and mean depth values at a site. Consequently, streamflow requirements determined for natural riffle sites may not be sufficient to protect habitat at altered sites, and flow requirements at altered sites may not provide sufficient flows for habitat protection in unaltered stream reaches. The Wetted-Perimeter and R2Cross methods, therefore, should not be applied globally. Because of Massachusetts' long history of settlement, many of the largest riffles in its streams have been altered to power former grist mills and sawmills. Consequently, less-altered, moderate-sized riffles that do not become runs during high flows, and that are among the first to dry or develop fish-passage problems may be more appropriate sites for application of the Wetted-Perimeter and R2Cross methods.

Flow variability is important for a healthy aquatic ecosystem. Water withdrawals or regulation that cause streamflow to be maintained at a minimum level over an extended period can be detrimental to a healthy ecosystem. The time period over which streamflow requirements are applied needs to be considered carefully when streamflow requirements are established. To account for seasonal variability, minimum streamflow requirements that are applied over a longer period need to be higher than those that are applied over shorter periods. Standard-setting methods identify seasonal streamflow requirements. These flow requirements are designed to provide sufficient habitat to sustain riverine fish communities over a period of about 4 months. The flow requirements must not only sustain fish communities through the low-flow portion of the summer, but also through other parts of the season that normally have higher streamflow. Regardless of what level of streamflow requirement is established, flows will at times fall below streamflow requirements. In contrast, the RVA is designed to preserve the natural variability in streamflow. The method allows lower minimum flows than standard-setting methods, but the timing and duration of the minimum flows are restricted to apply to a shorter period of time that mimics the stream's natural flow regime. The ability to maintain streamflows within a narrow target range would require active and coordinated management controls.

Methods for setting a minimum streamflow for habitat protection assume that summer low flow and habitat availability are limiting criteria for aquatic life. The methods compared in this report do not account for other flow-related factors that affect the quality of stream habitat such as water quality, temperature, or impoundment; nor do the methods directly quantify biological trade-offs for different flows or seasons. Other methods, such as the Instream Flow Incremental Methodology (IFIM) (Bovee and others, 1997), which was not used in this study, could be applied to account for factors other than flow as a limit on aquatic life, or to compare the effects of incremental differences in flow created by numerous alternative water uses upon specific species or life stages of fish or aquatic invertebrates. 
NEEDS FOR FURTHER STUDY

The relation between the degree to which an altered flow regime departs from the natural flow regime, and the resulting changes in the structure and composition of a stream's aquatic community, are poorly understood. To assess the effects of changes in streamflow on aquatic communities, studies are needed that target the communities that are dependent upon habitats likely to be affected by flow changes (Aadland, 1993). In a study of the relation between fish assemblages and flow in different stream habitats, Aadland (1993) concluded that riffle, raceway, and shallow-pool habitats were the most sensitive to flow fluctuations. Investigations of streamflow and habitat in the Ipswich River demonstrated that riffles are the first channel type to lose substantial habitat as discharge decreases, and also are the first channel type to become dry; therefore, assessments of fish and macroinvertebrate communities in riffles and nearby habitats may serve as a useful indicator of the effects of flow alterations on stream health. Application of a riffle-based approach in Massachusetts requires more information about the natural seasonal variation of hydraulic conditions in riffles and the variability of fish and macroinvertebrate assemblages that rely on riffle habitat for all or part of their life cycle.

The timing and duration of low flows is critical to the health of aquatic ecosystems. More information is needed regarding the time periods over which streamflow requirements should be applied, and the effects on aquatic communities when these requirements are not met. Further investigations of characteristics of fish communities affected by low-flow conditions, such as the percentages of fish in different habitat-use classifications within different habitats, the percentage of individuals that are pioneering or colonizing species, the length-frequency distribution and the number of species having missing age classes, and changes to fish biomass, are needed to develop metrics that are sensitive to degradation created by recurrent low flows for inclusion in IBIs. Long-term monitoring of fish populations in rivers where streamflow requirements have been established would improve the understanding of the relation between streamflow and the reproduction, recruitment, growth, and other seasonal life-history needs of stream fish (Tyus, 1990).

\section{SUMMARY}

Streamflows in the Ipswich River Basin are substantially affected by water-supply withdrawals that stress aquatic communities, cause fish and mussel kills during dry years, and limit the value of the Ipswich River as a biological, recreational, and scenic resource. In order to meet the requirements of the Massachusetts Water Management Act, the MADEP and MADEM need to determine streamflows that will maintain continuous flow in the Ipswich River, that will provide habitat adequate to sustain aquatic life during low-flow periods, and that will provide the seasonally variable flows necessary to sustain the ecological integrity of the Ipswich River. In order to meet these requirements, the USGS and MDFW, in cooperation with the MADEM and MADEP, conducted a study of the habitat, fish communities, and streamflow requirements for habitat protection of the Ipswich River and its tributaries.

The Ipswich River is in the Atlantic coastal plain and is primarily a low-gradient stream dominated by glide-and-pool habitat. Riffle-and-run habitats are uncommon, and most are associated with artificial features such as areas of fill, bridges, and old mill dams. Most habitat and cover features are closely related to the riparian vegetation; in forested reaches, cover features include undercut banks, exposed roots, and woody debris; in non-forested reaches cover features include overhanging vegetation, small woody debris, and aquatic vegetation. Most cover features are associated with the stream margins and banks. These features provide habitat only when the streamflow fully wets the channel bed and provides sufficient depth of water at the stream margins for edgewater habitat features to be usable. These features, however, become inaccessible when streamflows become so low that the channel recedes from the stream margins or the water depth at the stream margins is inadequate for the edgewater habitat features to be usable. During extreme low flows in the Ipswich River all that remains in most river reaches is a sand channel with few structural or cover features. Reaches that have the greatest gradient (riffles and runs) become exposed first and isolate deeper pools and depressions. In these isolated pools, water quality declines, and competition for food and space increases, which limits the survival of fish, mussels, and macroinvertebrates. 
Determinations of the quality of physical habitat are critical to any assessment of ecological integrity, but habitat assessments may not account for the effects of prior flow conditions that affect the aquatic environment. Assessments of stream habitat in the headwaters of the Ipswich River in early summer of 1998 indicated that good habitat is present, yet many of these sites were dry in 1999. Habitat quality does not appear to be a limiting factor in the Ipswich River if adequate streamflows are maintained.

To determine the effect of recurrent low flows on fish communities in the Ipswich River, fish were sampled in 27 stream reaches in the mainstem during August and September 1998. The Ipswich River fish community is dominated by warm-water fish that are tolerant of extended periods of low flow or impoundment. Dominant fish species sampled in the mainstem Ipswich River were redfin pickerel (Esox americanus), American eel (Anguilla rostrata), and pumpkinseed (Lepomis gibbosus), which together represented 41, 22, and 10 percent, respectively, of 4,745 fish sampled. Fluvial species are rare or absent. Many tributaries are isolated from the mainstem by dams and old mill ponds; therefore, few tributaries, which may maintain flow because they are affected minimally by withdrawals, serve as important areas of refuge for mainstem fish populations during extreme low flows. In comparison to fish communities in the Quinebaug and Lamprey Rivers, and a target fish community developed for inland New England streams, the Ipswich fish community could be expected to have higher percentages of fluvial-dependent and fluvial-specialist species were flow restored.

Indexes of Biotic Integrity (IBI) used in nearby New England states were determined to be relatively insensitive to flow stress. IBI scores calculated from fish data collected in 1998, a year when the Ipswich River maintained flow, were higher for warm-water and mixed-water IBIs than cold-water fish IBIs. Scores, however, were calculated only for sites that had flowing water; inclusion of sites that were dry in 1999 and had no fish would have resulted in substantially lower scores than those included in this analysis. Fish sampled during late summer of 1998 included some stocked trout, which indicate that the Ipswich River potentially could support cold-water fish, but extreme low flows and warmer temperatures may limit their survival.
Streamflow requirements that are considered necessary to support aquatic habitat were determined at two USGS gaging stations by means of the Tennant and New England Aquatic Base-Flow (ABF) methods, and at four critical low-flow riffle sites with the Tennant, $\mathrm{ABF}$, Wetted-Perimeter, and R2Cross methods, along with common flow statistics. In addition, the Range of Variability Approach (RVA) was used to determine monthly mean flows and to compute the flow variability at the study sites. Streamflows were simulated for the 1961-95 period with an HSPF precipitation-runoff model for conditions of no withdrawals and 1991 land use and for average 1989-93 withdrawals and 1991 land use (Zarriello and Ries, 2000). Model simulations were required because unregulated streamflow data are unavailable for the study sites.

Four ungaged riffles were chosen for determining streamflow requirements for habitat protection because of their sensitivity to low flows: Mill Street in North Reading/Reading, Log Bridge Road in Middleton/Danvers, Route 1 in Topsfield, and Mill Road in Ipswich/Hamilton. During declining flows, these riffles are among the first reaches to show habitat losses or develop fish-passage problems, and are the first to go dry. These riffles are critical sites for monitoring habitat losses on the Ipswich River. Streamflows that maintain good habitat in these critical riffles also appear to provide adequate habitat conditions in adjacent non-riffle reaches to sustain fish communities during summer low-flow periods.

Minimum streamflows for habitat protection for the summer season were determined at the four riffle-study sites by averaging the streamflow requirements from the Tennant 30-percent $\mathrm{QMA}_{\mathrm{MA}} \mathrm{ABF}$ median of monthly mean flow for August, Wetted-Perimeter, and R2Cross methods. These streamflows, normalized for drainage area, averaged $0.45\left(\mathrm{ft}^{3} / \mathrm{s}\right) / \mathrm{mi}^{2}$ for Mill Street, North Reading/Reading; $0.45\left(\mathrm{ft}^{3} / \mathrm{s}\right) / \mathrm{mi}^{2}$ for Log Bridge Road, Middleton; $0.44\left(\mathrm{ft}^{3} / \mathrm{s}\right) / \mathrm{mi}^{2}$ for Route 1, Topsfield; and $0.65\left(\mathrm{ft}^{3} / \mathrm{s}\right) / \mathrm{mi}^{2}$ for Mill Road, Ipswich. A single average minimum streamflow of $0.49\left(\mathrm{ft}^{3} / \mathrm{s}\right) / \mathrm{mi}^{2}$ was determined by averaging these minimum streamflows for each site.

Three of the four riffle-study sites (Mill Street, Log Bridge Road, and Mill Road) have altered channels that could be restored. The R2Cross method, which uses depth, wetted perimeter, and velocity criteria to determine a discharge that will maintain acceptable habitat in riffles, produced a high streamflow requirement at the Mill Road site in comparison to the 
other sites. The Wetted-Perimeter method produced an uncertain streamflow requirement at the Route 1 site because of a number of large boulders in the cross section. Consequently, alternative minimum streamflows for habitat protection were determined by averaging the Tennant 30-percent QMA, the ABF median of monthly mean flows for August for the simulated 1961-95 period under no withdrawals and 1991 land use, the wetted-perimeter streamflows required to maintain wetted perimeter for the three altered riffle sites, and the $\mathrm{R} 2$ Cross streamflow required to maintain flow criteria at the natural riffle site near Route 1. These streamflows, normalized for drainage area, averaged $0.47\left(\mathrm{ft}^{3} / \mathrm{s}\right) / \mathrm{mi}^{2}$ for Mill Street, North Reading/ Reading; $0.44\left(\mathrm{ft}^{3} / \mathrm{s}\right) / \mathrm{mi}^{2}$ for Log Bridge Road, Middleton; $0.39\left(\mathrm{ft}^{3} / \mathrm{s}\right) / \mathrm{mi}^{2}$ for Route 1, Topsfield; and $0.40\left(\mathrm{ft}^{3} / \mathrm{s}\right) / \mathrm{mi}^{2}$ for Mill Road, Ipswich. A single average minimum streamflow of $0.42\left(\mathrm{ft}^{3} / \mathrm{s}\right) / \mathrm{mi}^{2}$ was determined by averaging these selected minimum streamflows for each site.

Standard-setting methods, such as the Tennant, ABF default flows, Wetted-Perimeter, and R2Cross methods, were designed to identify a minimum streamflow that will provide sufficient habitat to sustain fish communities over the summertime. Streams, however, have a natural flow regime that varies within an annual cycle, between wet, normal, and dry years, and from upstream to downstream. Consequently, streamflows cannot be expected to meet a minimum summertime streamflow requirement at all sites or at all times.

Streamflows simulated by Zarriello and Ries for the 1961-95 period with no withdrawals and 1991 land use provide the best available estimate of naturalized streamflow conditions in the Ipswich River under current land-use conditions. For six sites from upstream to downstream, the medians of monthly mean streamflow for August, normalized for drainage area, were simulated to be $0.48\left(\mathrm{ft}^{3} / \mathrm{s}\right) / \mathrm{mi}^{2}$ at Mill Street, North Reading/Reading; $0.39\left(\mathrm{ft}^{3} / \mathrm{s}\right) / \mathrm{mi}^{2}$ at the South Middleton gage, $0.38\left(\mathrm{ft}^{3} / \mathrm{s}\right) / \mathrm{mi}^{2}$ at Log Bridge Road, Middleton/ Danvers; $0.27\left(\mathrm{ft}^{3} / \mathrm{s}\right) / \mathrm{mi}^{2}$ at Route 1 , Topsfield; $0.25\left(\mathrm{ft}^{3} / \mathrm{s}\right) / \mathrm{mi}^{2}$ at the Ipswich gage, and $0.27\left(\mathrm{ft}^{3} / \mathrm{s}\right) / \mathrm{mi}^{2}$ at Mill Road in Ipswich/Hamilton. The simulated streamflows also indicate that a streamflow threshold of $0.42\left(\mathrm{ft}^{3} / \mathrm{s}\right) / \mathrm{mi}^{2}$ may not be met for a period of several months during the summer at several downstream sites. For example, at Mill Street in North Reading/Reading, the medians of monthly mean streamflows for the summer months, normalized for drainage area, were $1.01,0.49,0.47$, and $0.51\left(\mathrm{ft}^{3} / \mathrm{s}\right) / \mathrm{mi}^{2}$ in June, July,
August, and September. At the Ipswich River gage, however, the medians of monthly mean streamflow for these summer months, normalized for drainage area, were $0.87,0.27,0.25$, and $0.23\left(\mathrm{ft}^{3} / \mathrm{s}\right) / \mathrm{mi}^{2}$, respectively. During a dry year, a streamflow threshold of $0.42\left(\mathrm{ft}^{3} / \mathrm{s}\right) / \mathrm{mi}^{2}$ rarely would be achieved between July and September at the downstream study sites.

As an alternative to a single minimum streamflow threshold, the Range of Variability Approach (RVA) developed by Richter and others (1997), was applied to the streamflows simulated by Zarriello and Ries (2000) for the 1961-95 period under no withdrawals and 1991 land use. According to the RVA, streamflow targets are defined by the 25 th- to 75 th-percentile ranges for the monthly mean streamflows and other low-flow statistics and measures of low flow. Averaged for the four riffle sites and two streamgaging stations, the 25 th- to 75 th-percentile ranges of monthly mean flow for the summer months, normalized for drainage area, were 0.64 to $1.40\left(\mathrm{ft}^{3} / \mathrm{s}\right) / \mathrm{mi}^{2}$ in June, 0.25 to $0.61\left(\mathrm{ft}^{3} / \mathrm{s}\right) / \mathrm{mi}^{2}$ in July, 0.20 to $0.54\left(\mathrm{ft}^{3} / \mathrm{s}\right) / \mathrm{mi}^{2}$ in August, and 0.24 to $0.51\left(\mathrm{ft}^{3} / \mathrm{s}\right) / \mathrm{mi}^{2}$ in September. Streamflows at the 25 th percentile, the lower ends of the target ranges, are lower than those determined by averaging results from the Tennant, ABF, WettedPerimeter, and R2Cross methods. The RVA method, however, restricts the magnitude, timing, frequency, and duration of low streamflows by requiring that streamflows be maintained within the 25 th- to 75 thpercentile ranges for flow statistics such as the annual 1-, 3-, 7-, 30-, and 90-day low flows, and other measures of low flow.

Maintenance of the RVA target flows determined from streamflows simulated by Zarriello and Ries (2000) for the 1961-95 period under no withdrawals and 1991 land use, would provide conditions that allow restoration of the aquatic ecosystem in the Ipswich River. This restoration also could be achieved by maintenance of a minimum streamflow requirement of about $0.42\left(\mathrm{ft}^{3} / \mathrm{s}\right) / \mathrm{mi}^{2}$ to $0.49\left(\mathrm{ft}^{3} / \mathrm{s}\right) / \mathrm{mi}^{2}$ for the summer period, together with higher streamflow requirements for other seasons. These flow restorations, combined with removal of dams and other barriers to fish passage, would allow fish communities to recover toward the goal of maintaining target communities consisting of more fluvial species in higher numbers. 


\section{REFERENCES CITED}

Aadland, L.P., 1993, Stream habitat types-their fish assemblages and relationship to flow: North American Journal of Fisheries Management, v. 13, p 790-806.

Angermeir, P.L., and Karr, J.R., 1986, Applying an index of biotic integrity based on stream-fish communitiesconsiderations in sampling and interpretation: North American Journal of Fisheries Management, v. 6, p. $418-429$.

Annear, T.C., and Conder, A.L., 1984, Relative bias of several fisheries instream flow methods: North American Journal of Fisheries Management, v. 4, p. 531-539.

Bain, M.B., Finn, J.T., and Booke, H.E., 1988, Streamflow regulation and fish community structure: Ecology, v. 69, no. 2, p. 382-392.

Bain, M.B., and Knight, J.G., 1996, Classifying stream habitat using fish community analyses, in Leclerc, Michel, Capra, Herve, Valentin, Sylvie, Boudreault, Andre, and Cote, Yvon, eds., Proceedings of the second IAHR Symposium on habitat hydraulics: Quebec, Canada., June Ecohydraulics 2000, Insitiute National de la Recherche Scientifique-Eau, Ste-Foy, p. B107B 117 .

Bain, M.B., and Stevenson, N.J., 1999, Aquatic habitat assessment-CCommon methods: Bethesda, Md., American Fisheries Society, $216 \mathrm{p}$.

Bain, M.B., and Travnichek, V.H., 1996, Assessing impacts and predicting restoration benefits of flow alterations in rivers developed for hydroelectric power production, in Leclerc, Michel, Capra, Herve, Valentin, Sylvie, Boudreault, Andre, and Cote, Yvon, eds., Proceedings of the second IAHR Symposium on habitat hydraulics: Quebec, Canada, June Ecohydraulics 2000, Insitiute National de la Recherche Scientifique-Eau, Ste-Foy, p. B543-B552.

Barbour, M.T., Gerritsen, J., Snyder, B.D., and Stribling, J.B., 1999, Rapid bioassessment protocols for use in streams and wadeable rivers-periphyton, benthic macroinvertebrates, and fish, second edition: Washington, D.C., U.S. Environmental Protection Agency, Office of Water, EPA 841-B-99-002, variously paged.

Barnes, H.H., 1967, Roughness characteristics of natural channeIs: U.S. Geological Survey Water-Supply Paper $1849,213 \mathrm{p}$.

Belding, D.L., 1921, A report upon the alewife fisheries of Massachusetts: Boston, Mass., Marine Fisheries Service, Massachusetts Division of Fish and Game, $135 \mathrm{p}$.
Bovee, K.D., Lamb, B.L., Bartholow, J.M., Stainaker, C.B., Taylor, Jonathon, and Henriksen, Jim, 1997, Stream habitat analysis using the Instream Flow Incremental Methodology: U.S. Geological Survey Biological Resources Division Information and Technology Report 1997-0006 (Interim Version), 172 p.

Castleberry, D.T., Cech, J.T., Jr., Erman, D.C., Hankin, David, Healey, Michael, Kondolf, G.M., Mangel, Marc, Mohr, Michael, Moyle, P.B., Nielsen, Jennifer, Speed, T.P., and Williams, J.G., 1996, Uncertainty and instream flow standards: Fisheries, v. 21 , no. 8 , p. $20-$ 21.

Cervione, M.A., Jr., Melvin, R.L., and Cyr, K.A., 1982, A method for estimating the 7-day, 10-year low flow of streams in Connecticut: Connecticut Water-Resources Bulletin no. 34, $17 \mathrm{p}$.

Charles Ritzi and Associates, 1987, Computation of USFWS aquatic base flow (ABF) for regulated streams: Winthrop, Maine, Charles Ritzi and Associates, $16 \mathrm{p}$.

Cortes, R.M.V., Ferreira, M.T., and Godinho, F.S., 1998, Benthic community organization in an intermittent lotic system: Verhantlungen Internationale Vereinigung für Theoretische und Angewandte Limnologie, v. 26, p. 1002-1007.

Currier, P.E., 2000, Summary of the draft instream flow rules, accessed November 16,2000, at URL http://www.des.state.nh.us/rivers/instream/archive/ studies_reports.htm/. New Hampshire Department of Environmental Services.

Denny, C.S., 1982, Geomorphology of New England: U.S. Geological Survey Professional Paper 1208, 18 p.

Dow, G.W., 1926, The River Agawam-An Essex County waterway: Topsfield, Mass., 11 p.

Dunbar, M.J., Gustard, A., Acreman, M.C., and Elliot, C.R.N., 1998, Overseas approaches to setting river flow objectives: Almondsbury, Bristol, U.K., Environmental Agency and Institute of Hydrology, R\&D Technical Report W6-161, 79 p.

Dunn, Thomas, and Leopold, L.B., 1978, Water in environmental planning: New York, W.H. Freeman and Co., $818 \mathrm{p}$.

Elliott, J.M., 1994, Quantitative ecology and the Brown Trout: New York, Oxford University Press, 286 p.

Emmett, W.W., 1975, The channels and waters of the upper Salmon River area, Idaho: U.S. Geological Survey Professional Paper 870-A, 42 p.

Espegren, G.D., 1996, Development of instream flow recommendations in Colorado using R2Cross: Denver, Colo., Water Conservation Board, 34 p. 
1998, Evaluation of the standards and methods used for quantifying instream flows in Colorado: Denver, Colo., Water Conservation Board, 18 p.

Fausch, K.D., and Bramblett, R.G., 1991, Disturbance and fish communities in intermittent tributaries of a western Great Plains River: Copeia, p. 659-674.

Fausch, K.D., Lyons, J., Karr, J. R., and Angermeier, P. L., 1990, Fish communities as indicators of environmental degradation: American Fisheries Society Symposium 8, p. 123-144.

Felt, J.B., 1834, History of Ipswich, Essex, and Hamilton: accessed on June 15, 2001, at URL http://john-slaughter.rootsweb.com//pswichHistory/ Historylntro.html.

Fitzpatrick, F.A., Waite, I.R., D'Arconte, P.J., Meador, M.R., Maupin, M.A., and Gurtz, M.E., 1998, Revised methods for characterizing stream habitat in the National Water-Quality Assessment Program: U.S. Geological Survey Water-Resources Investigations Report 98-4052, 67 p.

Gibson, G.R., Barbour, M.T., Stribling, J.B., Gerritsen, J., and Karr, J.R., 1996, Biological criteria-Technical guidance for streams and small rivers (revised edition): U.S. Environmental Protection Agency, EPA 822-B-96001,162 p.

Gillilan, D.M., and Brown, T.C., 1997, Instream flow protection-Seeking a balance in western water use: Washington, D.C., Island Press, 417 p.

Gippel, Christopher, 1996, Use of wetted perimeter in defining minimum environmental flows, in Leclerc, Michel., Capra, Herve, Valentin, Sylvie, Boudreault, Andre, and Cote, Yvon, eds., Proceedings of the second IAHR Symposium on habitat hydraulics: Quebec, Canada, June Ecohydraulics 2000, Insitiute National de la Recherche Scientifique-Eau, Ste-Foy, p. A571-A582.

Goldstein, R.M., Simon, T.P., Pearson, Eric, Schmidt, Konrad, and Enblam, J.W., 1994, Concepts for an index of biotic integrity for streams of the Red River of the North Basin, in North Dakota Water Quality Symposium Proceedings, March 1-31, Fargo, N.D., North Dakota State University Extension Service, p. 169-180.

Gorman, O.T., and Karr, J.R., 1978, Habitat structure and stream fish communities: Ecology, v. 59, p. 507-515.

Hagstrom, N.T., Humphreys, Michael, Hyatt, W.A., and Gerrish, W.B., 1995, A survey of Connecticut streams and rivers - statewide summary: Hartford, Bureau of Natural Resources, Fisheries Division, p. 80.
Halliwell, D.B., Langdon, R.W., Daniels, R.A., Kurtenbach, J.P., and Jacobson, R.A., 1999, Classification of freshwater fish species of the Northeastern United States for use in the development of indices of biological integrity, with regional applications, in Simon, T.P., ed., Assessing the sustainability and biological integrity of water resources using fish communities: Boca Raton, Fla., CRC Press, p. 301338.

Hansen, M.J., and Ramm, C.W., 1994, Persistence and stability of fish community structure in a southwest New York stream: American Midland Naturalist, v. 132, p. $52-67$.

Harvey, B.C., and Stewart, A.J., 1991, Fish size and habitat depth relationships in headwater streams: Oecologia, v. 87, p. $336-342$.

Hickey, J.T., and Diaz, G.E., 1999, From flow to fish to dollars-an integrated approach to water allocation: Journal of the American Water Resources Association, v. 35 , no. 5, p. 1053-1067.

Hicks, D.M., and Mason, P.D., 1991, Roughness characteristics of New Zealand Rivers: Wellington, New Zealand, Water Resources Survey, DSIR Marine and Freshwater, 329 p.

Horowitz, R.J., 1978, Temporal variability patterns and the distributional patterns of stream fishes: Ecological Monographs, v. 48, p. 307-321.

Hubbs, Clark, 1987, Summary of the Symposium, in Matthews, W.J., and Heins, D.C., eds., Community and evolutionary ecology of North American stream fishes: Norman, Okla., University of Oklahoma Press, p. 265267.

Jacobson, R.A., 1994, Application of the Index of biotic integrity to small Connecticut streams: Storrs, Conn., Master's Thesis, University of Connecticut, Storrs. 24 p.

Johnson, J.H., Deake, Standish, and Grant, C.E., 1934, Ipswich River System: Commonwealth of Massachusetts, Department of Conservation, Division of Fish and Game, letters reporting field surveys, $35 \mathrm{p}$.

Karim, Khalid, Gubbels, M.E., and Goulter, I.C., 1995, Review of determination of instream flow requirements with special application to Australia: Water Resources Bulletin, v. 31., no. 6., p. 1063-1077.

Karr, J.R., 1981, Assessment of biotic integrity using fish communities: Fisheries, v. 6, p. 21-27.

Karr, J.R., and Chu, E.W., 1999, Restoring life in running waters-Better biological monitoring: Washington, D.C., Island Press, 206 p.

Karr, J.R., and Dudley, D.R., 1981, Ecological perspectives on water quality goals: Environmental Management, v. 5, p. 55-68. 
Kershner, J.L., and Snider, W.M., 1992, Importance of a habitat level classification system to design instream flow studies, in Boon, P.J., Calow, P., and Petts, G.E., eds., River Conservation and Management: Chichester, John Wiley and Sons, p. 179-182.

Kulik, B.H., 1990, A method to refine the New England Aquatic Base Flow Policy: Rivers, v. 1, no. 1, p. 8-22.

Lang, Vernon, 1999, Questions and answers on the New England flow policy: Concord, N.H., U.S. Fish and Wildlife Service, 9 p.

Leathe, S.A., and Nelson, F.A., 1986, A literature evaluation of Montana's wetted perimeter inflection point method for deriving instream flow recommendations: Helena, Mont., Department of Fish, Wildlife, and Parks, $70 \mathrm{p}$.

Lobb, M.D., III, and Orth, D.J., 1991, Habitat use by an assemblage of fish in a large warmwater stream: Transactions of the American Fisheries Society, v. 120, p. $65-78$.

Lohr, S.C., 1993, Wetted stream channel, fish-food organisms and trout relative to the wetted perimeter inflection method: Bozeman, Mont., Montana State University, Ph.D. dissertation, $246 \mathrm{p}$.

Lonzarich, D.G., Warren, M.L., and Lonzarich, M.R.E., 1998, Effects of habitat isolation on the recovery of fish assemblages in experimentally defaunated stream pools in Arkansas: Canadian Journal of Fisheries and Aquatic Sciences, v. 55, p. 2141-2149.

Mackey, P.C., Barlow, P.M., and Ries, K.G., III, 1998, Relations between discharge and wetted perimeter and other hydraulic-geometry characteristics at selected streamflow-gaging stations in Massachusetts: U.S. Geological Survey Water-Resources Investigations Report 98-4094, 44 p.

Massachusetts Department of Environmental Protection, 1990, Commonwealth of Massachusetts Summary of Water Quality, Appendix I Basin/Segment Information: Westborough, Mass., Massachusetts Department of Environmental Protection, Division of Water Pollution Control, Publication No. 16, 501-107-25-11-90-CR, variously paged.

1999, Massachusetts Surface Water Quality Standards: Worcester, Mass., Massachusetts Department of Environmental Protection, 314CMR 4.00, p. 65-79.

Matthews, W. J., 1998, Patterns in freshwater fish ecology: New York, Chapman and Hall, $756 \mathrm{p}$.

Maxted, J.R., Barbour, M.T., Gerritsen, J., Poretti, V., Primrose, N., Silva, A., Penrose, D., and Renfrow, R., 2000, Assessment framework for mid-Atlantic coastal plain streams using benthic macroinvertebrates: Journal of the North American Benthological Society, v. 19, no. 1 , p. 128-144.
Nehring, R.B., 1979, Evaluation of instream flow methods and determination of water quantity needs for streams in the State of Colorado: Fort Collins, Colo., Division of Wildlife, $144 \mathrm{p}$.

Nelsen, F.A., 1984, Guidelines for using the wetted perimeter (WETP) computer program of the Montana Department of Fish, Wildlife, and Parks: Bozeman, Mont., Montana Department of Fish, Wildlife, and Parks, variously paged.

Orth, D.J., and Leonard, P.M., 1990, Comparison of discharge methods and habitat optimization for recommending instream flows to protect fish habitat: Regulated Rivers-Research and Managements, v. 5, p. 129-138.

Panfil, M.S., and Jacobson, R.B., 2000, Hydraulic modeling of in-channel habitats in the Ozark Highlands of Missouri-Assessment of physical habitat sensitivity to environmental change: U.S. Geological Survey, accessed April 16, 2001, at URL http:// www.derc.usgs.gov/rss/rfmodel/default.htm/.

Parker, G.W., Ries, K.G., III, and Socolow, R.S., 1998, The flood of June 1998 in Massachusetts and Rhode Island: U.S. Geological Survey Fact Sheet 110-98, 4 p.

Plafkin, J.L., Barbour, M.T., Porter, K.D., Gross, S.K., and Hughes, R.M., 1989, Rapid bioassessment protocols for use in streams and rivers-benthic macroinvertebrates and fish: U.S. Environmental Protection Agency EPA/440/4-89/001, variously paged.

Poff, N.L., Allen, J.D., Bain, M.B., Karr, J.R., Prestagaard, K.L., Richter, B.D., Sparks, R.E., and Stromberg, J.C., 1998, The natural flow regime-a paradigm for river conservation and restoration: Bioscience, v. 47, p. 769 784.

Poff, L.N., and Ward, J.V., 1989, Implications of streamflow variability and predictability for lotic community structure: Canadian Journal of Fisheries and Aquatic Sciences, v. 46, p. 1805-1817.

Rantz, S.E., and others, 1982, Measurement and computation of streamflow: U.S. Geological Survey Water-Supply Paper 2175, 2 v., 631 p.

Richter, B.D., Baumgartner, J.V., Braun, D.P., and Powell, Jennifer, 2001, A spatial assessment of hydrologic alteration within a river network: The Nature Conservancy Freshwater Initiative, accessed April 16, 2001, at URL http://www.freshwaters.org/ccwp/ down.html/.

Richter, B.D., Baumgartner, J.V., Powell, Jennifer, and Braun, D.P., 1996, A method for assessing hydrologic alteration within ecosystems: Conservation Biology, v., 10, p. 1163-1174. 
Richter, B.D., Baumgartner, J.V., Wigington, Robert, and Braun, D.P., 1997, How much water does a river need?: Freshwater Biology, v. 37, p. 231-249.

Ries, K.G., III, 1997, August median streamflows in Massachusetts: U.S. Geological Survey WaterResources Investigations Report 97-4190, 27 p.

Ries, K.G., III, and Friesz, P.J., 2000, Methods for estimating low-flow statistics for Massachusetts streams: U.S. Geological Survey Water-Resources Investigations Report 00-4135, 81 p.

Roth, N.E., Southerland, M.T., Mercurio, Ginny, Chaillou, J.C., Heimbuch, D.G., Seibel, J.C., Versar, Inc., and Post, Buckley, Schuh, and Jernigan, Inc., 1997, State of the streams-1995-1997 Maryland biological stream survey results: Annapolis, Md., Maryland Department of Natural Resources, chap. 5, 24 p.

Schlosser, I.J., 1982, Fish community structure and function along two habitat gradients in a headwater stream: Ecological Monographs, v. 52, p. 395-414.

1987, A conceptual framework for fish communities in small warmwater streams, in Matthews, W.J., and Heins, D.C., eds., Community and evolutionary ecology of North American stream fishes: Norman, Okla., University of Oklahoma Press, p. 17-24.

1995, Critical landscape attributes that influence fish population dynamics in headwater streams: Hydrobiologia, v. 303, p. 71-81.

Searcy, J.K., 1959, Flow-duration curves, manual of hydrology-Part 2, Low-flow techniques: U.S. Geological Survey Water-Supply Paper 1542-A, 33 p.

Shearman, J.O., 1990, User's manual for WSPRO-a computer model for water surface profile computations: U.S. Department of Transportation, Publication No. FHWA-IP-89-027, 177 p.

Simon, T.P., ed., 1999, Assessing the sustainability and biologic integrity of water resources using fish communities: Boca Raton, Fla., CRC Press, 671 p.

Simon, T.P., and Lyons, John, 1995, Application of the index of biotic integrity to evaluate water resource integrity in freshwater ecosystems, in Davis, W.S., and Simon, T.P., eds., Biological assessment and criteria-Tools for water resource planning and decision making: Boca Raton, Fla., Lewis Publishers, p. 245-262.

Simonson, T.D., and Lyons, John, 1995, Comparison of catch per effort and removal procedures for sampling stream fish assemblages: North American Journal of Fisheries Management, v. 15, p. 419-427.
Simonson, T.D., Lyons, John, and Kanehl, P. D., 1993, Guidelines for evaluating fish habitat in Wisconsin streams: St. Paul, Minn., U.S. Department of Agriculture, Forest Service, North Central Experiment Station, General Technical Report NC-164, 36 p.

Socolow, R.S., Comeau, L.Y. Casey, R.G., and Ramsbey, L.R. 1996, Water resources data for Massachusetts and Rhode Island-Water year 1995: U.S. Geological Survey Water-Data Report, USGS-WDR-MA-RI-95-1. 428 p.

Socolow, R.S., Comeau, L.Y., Zanca, J.L., and Ramsbey, L.R., 1999, Water resources data for Massachusetts and Rhode Island -Water year 1998: U.S. Geological Survey Water-Data Report, USGS-WDR-MA-RI-98-1, $438 \mathrm{p}$.

Socolow, R.S., Leighton, C.R., Zanca, J.L., and Ramsbey, L.R., 1998, Water resources data for Massachusetts and Rhode Island-Water year 1997: U.S. Geological Survey Water-Data Report, USGS-WDR-MA-RI-97-1, 334 p.

Socolow, R.S., Murino, Dominic, Jr., Casey, R.G., and Ramsbey, L.R. 1997, Water resources data for Massachusetts and Rhode Island-Water year 1996: U.S. Geological Survey Water-Data Report, USGS-WDRMA-RI-96-1, $367 \mathrm{p}$.

Socolow, R.S., Zanca, J.L., Murino, Domenic, Jr., and Ramsbey, L.R., 2000, Water resources data for Massachusetts and Rhode Island-Water year 1999: U.S. Geological Survey Water-Data Report, USGS-WDRMA-RI-99-1 401 p.

Sokal, R.R., and Rohl, F.J., 1995, Biometry-The principles and practice of statistics in biological research: New York, W.H. Freeman and Co., 887 p.

Spence, A.M., Smith, M.L., and Nairn, R.W., 1999, Ecological assessment of several Oklahoma streams through evaluation of fish communities and habitat in a drought year: Proceedings, Oklahoma Academy of Science, v. 79, p. 61-72.

Stalnaker, C.B., 1990, Minimum flow is a myth, in Bain, M.B., ed., Ecology and assessment of warmwater streams-workshop synopses: Washington D.C., U.S. Fish and Wildlife Service Biological Report 90(5) p. 31-33.

Stalnaker, Clair, Lamb, B.L., Henriksen, Jim, Bovee, Ken, and Bartholow, John, 1995, The instream flow incremental methodology - A primer for IFIM: Washington, D.C., U.S. Department of the Interior, National Biological Service, Biological Report 29, 45 p. 
Tennant, D.L., 1976, Instream flow regimens for fish, wildlife, recreation, and related environmental resources, in Instream flow needs, Volume II: Boise, Idaho, Proceedings of the symposium and specialty conference on instream flow needs, May 3-6, American Fisheries Society, p. 359-373.

Thomas, M.P., 1966, Effect of glacial geology upon the time distribution of streamflow in eastern and southern Connecticut: U.S. Geological Survey Professional Paper 550-B, p. B209-B212.

Tyrus, H.M., 1990, Effects of altered stream flows on fishery resources: Fisheries, v. 15, no. 3, p. 18-20.

U.S. Fish and Wildlife Service, 1981, Interim regional policy for New England stream flow recommendations: Newton Corner, Mass., U.S. Fish and Wildlife Service, $3 \mathrm{p}$.

Wandle, S.W., Jr., 1984, Gazetteer of hydrologic characteristics of streams in Massachusetts-Coastal river basins of the North Shore and Massachusetts Bay: U.S. Geological Survey Water-Resources Investigations Report 84-4281, 60 p.
Wandle, S.W., Jr., and Randall, A.D., 1994, Effects of surficial geology, lakes and swamps, and annual water availability on low flows of streams in central New England, and their use in low-flow estimation: U.S. Geological Survey Water-Resources Investigations Report 93-4092, 57 p.

Ward, J.V., and Stanford, J.A., 1983, The serial discontinuity concept of lotic ecosystems, in Fontaine, T.D., and Bartell, S.M., eds., Dynamics of lotic ecosystems: Ann Arbor, Mich., Ann Arbor Science, p. 29-42.

Watson, R.T., Zinyowera, M.C., and Moss R.H., eds., 1998, The regional impacts of climate change-An assessment of vulnerability: New York, Cambridge University Press, Intergovernmental Panel on Climate Change, 518 p.

Wickliff, E.L., 1945: Some effects of droughts and floods on stream fish: Columbus, Ohio, Ohio State University Engineering Experimental Station News, v. 17, no. 2, p. $23-30$.

Zarriello, P.J., and Ries, K.G., III, 2000, A precipitationrunoff model for analysis of the effects of water withdrawals on streamflow, Ipswich River basin, Massachusetts: U.S. Geological Survey WaterResources Investigation Report 00-4029, 99 p. 